\title{
Modernising the Constitution - A Courts Act
}

\author{
Graham McBain ${ }^{1,2}$ \\ ${ }^{1}$ Peterhouse, Cambridge, UK \\ ${ }^{2}$ Harvard Law School, USA \\ Correspondence: Graham McBain, 21 Millmead Terrace, Guildford, Surrey GU2 4AT, UK. E-mail: \\ gsmcbain@aol.com
}

Received: January 17, 2021 Accepted: March 3, 2021 Online Published: March 6, 2021

doi:10.5539/ilr.v10n1p195

URL: https://doi.org/10.5539/ilr.v10n1p195

Two prior articles have looked at modernising the law on the Crown, see Modernising the Constitution - A Crown Act ${ }^{1}$ and Modernising the Constitution - A Parliament Act. ${ }^{2}$ These Crown and Parliament Acts should, then, be consolidated into one Constitution Act - which Act will consolidate c. 130 Acts in total. Also needed are the following pieces of legislation, a:

\section{- Courts Act; and a \\ - Government Act.}

A Courts Act is required in order to consolidate c. 20 Acts relating to the courts (there are also a further 37 Acts mainly concerned with civil and criminal procedure; these should be consolidated into two Justice Acts). Also, a Courts Act is required to abolish old courts that no longer have any useful function. And, to rationalise others. The basic problem with our English courts system today, is that it (conspicuously) fails to meet the need for a streamlined and efficient means of legal process. One which enables civil and criminal cases to be processed expeditiously - with the minimum bureaucracy. Instead, the present Victorian based court system is wholly out of kilter with commercial (and State) needs. Thus, it is almost unintelligible. A court system replete with historical anomalies and based on antiquated legislation which does not inter-lock or in respect of which there are many glitches. Further, the English legal system is:

- weighed down with too many tiers of courts,

- $\quad$ too much bureaucracy; and

- an overall structure that lacks rhyme or reason.

That is, a legal system which is something of a mystery even to many (most) lawyers and judges. For example, if one were to ask the present Lord Chief Justice - or the head of the Supreme Court - even the simplest of questions 'Please tell me what English courts presently exist?', they would, probably, shake their heads sadly and reach for the bottle. ${ }^{3}$ Mervyn Peake's great novel 'Gormenghast' could have been based on the English court system. ${ }^{4}$

In conclusion, all material (legislative and common law) relating to the English courts should be consolidated into one Courts Act ${ }^{5}$ - something which is not difficult. Also, obsolete courts should be abolished. This article considers such matters.

\footnotetext{
${ }^{1}$ GS McBain, Modernising the Constitution - A Crown Act (2021) International Law Research, vol 10, no 1, pp 13-100. The article asserts that some 60 Acts relating to the Crown should be consolidated into one Crown Act.

${ }^{2}$ GS McBain, Modernising the Constitution - A Parliament Act (2021) International Law Research, vol 10, no 1, pp 13-100. The article asserts that c. 68 Acts relating to the Crown should be consolidated into one Crown Act. To this number might be added the House of Commons Members' Fund Act 2016 and the Parliamentary Buildings (Restoration and Renewal) Act 2019.

${ }^{3}$ After all, what judge or lawyer is familiar with the long list of courts that, technically, still exist but which have not sat since, for example, 1835 (Court of the Duchy of Lancaster) or for hundreds of years (the Cinque Ports' Court of Shepway), see 15.

${ }^{4}$ M Peake, Gormenghast (1950, part of a trilogy). In fact, as a child, Peake had lived in China and, thus, would have known of the structure of the government of the Ching empire (replaced, in 1911, by a republic).

${ }^{5}$ If county and magistrates' courts are retained, then the legislation on them should be consolidated in 2 separate Acts, see 11 \& 12.
} 


\section{INTRODUCTION}

There have been a number of legal texts discussing the courts system in general over the centuries. ${ }^{6}$ However, most of these are out of date. A useful description of the court system as it existed at the turn of the $20^{\text {th }}$ century may be found in Halsbury, Laws ( $1^{\text {st }}$ edition, 1909, vol 9) and the subsequent demise of various courts may be tracked by reviewing later editions of this text. ${ }^{7}$ Recent articles by the author which deal with the modernisation of the courts system comprise the following:

- Abolishing Various Obsolete Courts (2012) ('M1'); ${ }^{8}$

- Modernising the English Court System - Time for a Gastric Band (2013)('M2'). ${ }^{9}$

These are referred to in this article. For legislation which governs the English court system, see Appendix $\boldsymbol{A}$.

\section{PRESENT COURT STRUCTURE}

The present English court system consists of the following:

\begin{tabular}{lll} 
Appeal courts & $\begin{array}{l}\text { Supreme Court (SC) } \\
\text { Court of Appeal (CA) }\end{array}$ & $\begin{array}{l}\text { Judicial C-ee of the Privy Council (JCPC) } \\
\text { Court Martial Court of Appeal (CMCA) }\end{array}$ \\
\hline Senior courts & $\begin{array}{l}\text { High Court (civil) (HC) } \\
\text { Crown Court (criminal) (CC) }\end{array}$ \\
Lower courts & County Court (civil) & \\
& Magistrates' Courts (criminal) &
\end{tabular}

The purpose of this article is to indicate that the above court structure should be modernised and streamlined. This can be achieved by taking the following steps:

- $\quad$ Abolish the $\mathrm{JCPC}^{10}$

- $\quad$ Merge the CMCA into the $\mathrm{CA}^{11}$

- $\quad$ Merge the $\mathrm{CC}$ into the $\mathrm{HC}^{12}$

- Merge county and magistrates' courts into the $\mathrm{HC}^{13}$

- Abolishing obsolete courts.

The result would be a 3 tier system, without all the excrescences and historical anomalies of the current one. A court structure which is readily understood by everyone. One that can dispense justice speedily. A Courts Act could achieve this and one has no doubt that - leaving one or two vested interests and a few civil servants aside no one would object, lawyers included. ${ }^{14}$ Such would also save copious amounts of money for the taxpayer and the government.

\section{OPENING STATEMENT}

All of the Supreme Court (SC), Court of Appeal (CA), High Court (HC) and Crown Court (CC) are statutory creations. However, regrettably, the legislation on them is as clear as mud. This derives from two basic problems:

- The Supreme Court Act 1981 (the '1981 Act') dealt with the CA, HC and CC only, because the SC had not been created then (it was the Judicial Committee of the House of Lords at that time). The 1981 Act consolidated much material on these courts. However, it left over pieces relating to these courts contained in older legislation (in particular, in various Administration of Justice Acts);

\footnotetext{
${ }^{6}$ For texts, see Sweet and Maxwell, A Legal Bibliography of he British Commonwealth of Nations (1957, 2 vols). Post-1957, general legal texts on the legal system discuss the main courts presently operating (and Halsbury, Statutes, refers to older and obsolete ones).

${ }^{7}$ Halsbury, Laws of England (1 st ed, 1907-17 with supp; 2nd ed, 1931-42, with supp; 3rd ed, 1953-63 with supp; 4th ed, 1973 with supp, 5th ed, 2008 with supp)

${ }^{8}$ (2012) Coventry LJ, vol 17, no 1, pp 25-55.

${ }^{9}$ (2013) Journal of Politics and Law, vol 6, no 3, pp 17-44. For the forest courts of the New Forest and the Forest of Dean, see GS McBain, Abolishing some more Obsolete Crown Prerogatives: Pt 2 (2011) Liverpool LR, pp 293-8.

${ }^{10}$ The JCPC hears very few cases each year now.

${ }^{11}$ Ibid.

${ }^{12}$ This would create one court with plenary jurisdiction over criminal and civil matters.

${ }^{13}$ Ibid. County courts are a Victorian statutory creation (from 1846) designed to handle cases which were relatively simple or where larger sums of money were not involved. Today, this is not the issue. The issue is the experience of the judge and not the name of the court.

${ }^{14}$ Today, the large majority of law firms (and barristers) make their money through throughput - not through drawing things out as long as possible.
} 
- When the SC was created by the Constitutional Reform Act 2005 (the '2005 Act') that Act should have been a consolidation Act which repealed the 1981 Act as well as the older legislation. Instead, a 'lazy' option was taken. ${ }^{15}$ The 2005 Act followed the 1981 Act in major part when defining the constitution of the SC. However, it left the 1981 Act extant and simply labelled the CA, HC and $\mathrm{CC}$ as 'senior courts'.

Hence a legal 'dog's dinner' was created. This obscured the fact that the wording for all of the SC (in 1981, the Judicial Committee of the House of Lords), CA, HC and CC had (and should have) a high degree of commonality. Also, that the law on the jurisdiction of these courts, their divisions, business etc could have been simply set out in one consolidation Act. As it is, that is the past. The purpose of this article is to re-state - in a new Courts Act the wording in the 2005 Act (which is better than that in the $1981 \mathrm{Act}$ ) and to enable the law on the SC, CA and $\mathrm{HC}$ to be simplified - removing historical anomalies and setting out things in a user-friendly manner. This article also argues that the $\mathrm{CC}$ should merge with the $\mathrm{HC}$. And, that the latter should - like the $\mathrm{CA}$ - have only 2 divisions (criminal and civil).

In short, the architecture of the English court system should be greatly improved - enhancing intelligibility and efficiency as well as saving costs and cutting out unnecessary bureaucracy.

\section{THE SUPREME COURT ('SC')}

\section{(a) Constitution - SC}

This SC is a statutory creation. It derives from the 2005 Act. Section 23 (The Supreme Court) states:

(1) There is to be a Supreme Court of the [UK].

(2) The court consists of the persons appointed as its judges by [HM] by letters patent, but no appointment may cause the full-time equivalent number of judges of the court at any time to be more than 12 .

(3) $[\mathrm{HM}]$ may from time to time by Order in Council amend [ss] (2) so as to increase or further increase the maximum full-time equivalent number of judges of the court.

(4) No recommendation may be made to [HM] in Council to make an Order under [ss] (3) unless a draft of the Order has been laid before and approved by resolution of each House of Parliament.

(5) $[\mathrm{HM}]$ may by letters patent appoint one of the judges to be President and one to be Deputy President of the court.

(6) The judges other than the President and Deputy President are to be styled "Justices of the Supreme Court".

(7) The court is to be taken to be duly constituted despite any vacancy in the office of President or Deputy President.

(8) For the purposes of this [s], the full-time equivalent number of judges of the court is to be calculated by taking the number of full-time judges and adding, for each judge who is not a full-time judge, such fraction as is reasonable. ${ }^{16}$

The above wording in this 2005 Act was based on earlier legislation - the 1981 Act, later, called the Senior Courts Act 1981. Thus, in a Courts Act, it should be synchronised for all three. ${ }^{17}$ Also, it should be updated. For example, the word 'judge' is more usual in legal and general parlance, today, as opposed to the word 'justice'. And, foreshortening should be permitted (e.g. 'Supreme Court of the UK', 'Supreme Court' and 'Supreme Court judge'). In conclusion, the above provisions are (and should be) common for all of the SC, CA and HC. Therefore, they should be placed in a Courts Act and synchronised for these courts - to enable easy reading and to cut out minor changes in language between the 2005 and 1981 Acts.

\section{(b) $\underline{\text { Jurisdiction - SC }}$}

The SC is an appeal court - as opposed to one of first instance. Thus, what jurisdiction it has is appellate. In respect of an appeal to the SC in a civil case, the 2005 Act, s 40, states:

An appeal lies to the [SC] from any order or judgment of the [CA] in England and Wales in civil proceedings.

Other legislation provides for appeals to the SC in criminal cases.

- For appeals by the $\underline{\mathbf{C A}}$ to the SC, the legislation is the Criminal Appeal Act 1968, s: 33 (right of appeal to SC), 34 (application for leave to appeal), 35 (hearing and disposal of case), 36 (bail on appeal by defendant), 37 (detention of defendant on appeal by the Crown), 37A (continuation of community treatment order on appeal by the Crown), 38 (presence of defendant at hearing), 43 (effect of appeal on sentence), 44 (powers of CA exercisable by single (CA or HC) judge), 44A (appeals in cases of death), s 45 (meaning of a single judge).

\footnotetext{
${ }^{15}$ There may also have been political considerations.

${ }^{16} \mathrm{~s} 24$ (first members of the court) is spent.

${ }^{17}$ e.g. s 23 should apply to all of the SC. CA and HC, with slight amendment, see draft Courts Act, Appendix $C$.
} 
- For appeals by the $\underline{\mathbf{H C}}$ to the SC (leap frog appeals), the legislation is the Administration of Justice Act 1960, s 1 (right of appeal), 2 (application for leave to appeal), 4 (admission of appellant to bail), 5A (power to order detention or admission to bail of defendant),

5 (power to order continuation of community treatment order), 6 (computation of sentence where bail granted), 9 (procedure); ${ }^{18}$

As for the SC's jurisdiction in relation to other courts, the 2005 Act, s 41 (relation to other courts etc) states:

(1) Nothing in this Part is to affect the distinctions between the separate legal systems of the parts of the [UK].

(2) A decision of the [SC] on appeal from a court of any part of the [UK], other than a decision on a devolution matter, is to be regarded as the decision of a court of that part of the [UK].

(3) A decision of the [SC] on a devolution matter - (a) is not binding on that Court ${ }^{19}$ when making such a decision; (b) otherwise, is binding in all legal proceedings.

(4) In this [s] "devolution matter" means - (a) a question referred to the [SC] under [s] 99 or 112 of the Government of Wales Act 2006, [s] 33 of the Scotland Act 1998 (c. 46) or [s] 11 of the Northern Ireland Act 1998 (c. 47); (b) a devolution issue as defined in [sch] 9 to the Government of Wales Act 2006 (c. 38), [sch] 6 to the Scotland Act 1998 or [sch] 10 to the Northern Ireland Act 1998.

In the case of jurisdiction in respect of the SC (and, indeed, the other courts) it may be noted that:

- the drafting is peculiarly poor and, often, it contains minor mis-matches;

- $\quad$ there are common provisions in respect of the CA and the $\mathrm{HC}$ appeals process (e.g. as to the application for leave to appeal, bail on appeal etc). They should be set out in a schedule to the Courts Act.

- the provisions in respect of criminal appeals from the $H C$ to the $S C$ should follow those of appeals from the $C A$ to the SC (the latter are contained in the Criminal Appeal Act 1968 and are better drafted).

\section{(c) Due Constitution - SC}

The 2005 Act, s 42 (composition) states:

(1) The [SC] is duly constituted in any proceedings only if all of the following conditions are met - (a) the court consists of an uneven number of judges; (b) the court consists of at least three judges; (c) more than half of those judges are permanent judges.

(2) [Paras] (a) and (b) of [ss] (1) are subject to any directions that in specified proceedings the court is to consist of a specified number of judges that is both uneven and greater than three.

(3) [Para] (b) of [ss] (1) is subject to any directions that in specified descriptions of proceedings the court is to consist of a specified minimum number of judges that is greater than three.

(4) This [s] is subject to [s] 43. [i.e. changes in composition]

(5) In this [s] - (a) "directions" means directions given by the President of the court; (b) "specified", in relation to directions, means specified in those directions; (c) references to permanent judges are references to those judges of the court who are not acting judges under $[\mathrm{s}] 38$.

(6) This $[s]$ and [s] 43 apply to the constitution of the court in any proceedings from the time judges are designated to hear the proceedings. ${ }^{20}$

In conclusion, this section relating to due constitution is also common to the CA and the HC and all of them should be set out in a schedule to a Courts Act.

\section{(d) Business - SC}

Further sections of the 2005 Act deal with the 'business' of the SC, viz.
- $\quad$ Staff and resources
$(\text { ss } 48-51)^{21}$
- $\quad$ Court security
$(\text { ss } 51 \mathrm{~A}-\mathrm{E})^{22}$

\footnotetext{
${ }^{18}$ There are also more general sections in this Act on: publication of information relating to proceedings in private (s 12), appeal in cases of contempt of court (s 13), procedure on application for habeas corpus (s 14), appeal in habeas corpus proceedings (s 15), interpretation (s 17), provisions as to NI (s 18). These also should be placed in a Courts Act

${ }^{19}$ It is not clear what court is referred to. It seems it is the SC.

${ }^{20}$ See also 2005 Act, s 43 (changes in composition).

${ }^{21} \mathrm{~s} 48$ (chief executive), 49 (officers and staff), 50 (accommodation and other resources), 51 (system to support court in carrying on business).

${ }^{22} \mathrm{~s} 51 \mathrm{~A}$ (security officers), 51B (powers of search, exclusion, removal and restraint), 51C (surrender, seizure and retention of knives and other articles), 51D (regulations about retention of knives and other articles), 51E (assaulting and obstructing SC officers).
} 
- $\quad$ Procedure

- Fees

- Annual report

- $\quad$ Seal and supplementary $(\text { ss } 45-7)^{23}$

(ss 52-3) ${ }^{24}$

$(\mathrm{s} 54)^{25}$

$(\text { ss } 55-60)^{26}$

In respect of the above:

- the issue of a seal and the making of rules are also common to the CA and the HC (also, the Crown Court) and this should be set out in a Courts Act.

- the other sections are administrative in nature (others are spent or amend other legislation) and - to prevent this material clogging up the text of a Courts Act - they should be set out in a schedule to the Act or in an SI, which would be more easily capable of amendment.

- further, consideration should be given to whether various sections - in the light of the passage of time - are still required in respect of the SC. For example, could the cost of security officers (s 51A) and the need for powers of search (s 51B) etc not be avoided by employing an ordinary police officer(s), who would have additional powers other than those set out in the 2005 Act? Would such not reduce costs?

In conclusion, this section should be set out in a schedule to a Courts Act.

\section{(e) Other Matters - SC}

Other sections of the 2005 Act deal with the appointment of SC judges. viz.
- $\quad$ Appointment
(ss $25-27 \mathrm{~B})^{27}$
- Terms of appointment
$(\text { ss } 32-7)^{28}$
- $\quad$ Acting judges
(ss 38-9 $)^{29}$
- $\quad$ Specially qualified advisers
$(\mathrm{s} 44)^{30}$

Elsewhere in the 2005 Act, there are sections which deal with the appointment of judges generally as well as with judicial discipline, viz.

- Judicial appointments (ss 63-107);

- Judicial discipline (ss 108-21);

- $\quad$ Encouragement of diversity (s 137A).

Given the high degree of commonality, it would seem much better if all of this material was gathered into a SI. Not least, to enable easier amendment. Also, in the case of the SC - and in light of the operation of the SC since 2006 - are acting judges (s 38), supplementary panels (s 39) and specially qualified advisers (s 44) really required?

\section{(f) Other Matters - 2005 Act}

As well as the above which relates to the SC in particular, the 2005 Act contains sections ${ }^{31}$ on the:

- Judicial Appointments Commission (s 61)

- Judicial Appointments and Conduct Ombudsman (s 62).

This material should also be contained in a Courts Act.

\footnotetext{
${ }^{23} \mathrm{~s} 45$ (making of rules), 46 (procedure after rules made), 47 (photography etc).

${ }^{24}$ s 52 (fees), s 53 (fees: supplementary).

${ }^{25} \mathrm{~s} 54$ (annual report).

${ }^{26}$ s 55 (seal), 56 (records of the SC amends), 57 (proceedings under jurisdiction transferred to the SC, spent), 58 (NI Act 1998: excepted and reserved matters relating to the [SC], amends), 59 (renaming of [SC] of England and Wales and NI, spent), s 60 (interpretation of pt 3 ).

${ }^{27} \mathrm{~s} 25$ (qualification for appointment), 26 (selection of members of the court), 27 (selection process), 27A (regulations about selection process), 27B (selection guidance: supplementary).

${ }^{28} \mathrm{~s} 32$ (oath of allegiance and judicial oath), 33 (tenure), 34 (salaries and allowance), 35 (resignation and retirement), 36 (medical retirement), 37 (pensions).

${ }^{29}$ s 38 (acting judges), 39 (supplementary panel).

${ }^{30} \mathrm{~s} 44$ (specially qualified advisers).

${ }^{31}$ It also contains material on the LC, see ss 2-22, which may be set out in a schedule to a Courts Act.
} 


\section{(g) Conclusion}

A Courts Act should contain the entire $2005 \mathrm{Act}^{32}$ - but modernised. To prevent the clogging up of the Act, all administrative provisions should be set out in a schedule to the Act or in a SI. The latter permits easier amendment which is appropriate in the case of fees etc.

\section{JUDICIAL C-EE OF THE PRIVY COUNCIL}

The JCPC only hears a limited number of appeals. ${ }^{33}$ These comprise a few statutory appeals (now rare) as well as appeals from various British Overseas Territories ('BOT') $)^{34}$ and from a few foreign countries. The operation of the JCPC is governed by various (antiquated) pieces of Victorian legislation (see also Appendix B). ${ }^{35}$

\section{(a) Statutory Appeals}

In Victorian times, the JCPC inherited appeal rights in rather a quixotic fashion. ${ }^{36}$ As it is, today, it only has the right to hear the following:

- $\quad$ Appeals from the Disciplinary Committee - Royal College of Vets. Appeals in respect of other healthcare professionals have been transferred to the HC. This one also should since it is now anomaly;

- Disputes - House of Commons Disqualification Act 1975. The JCPC hears appeals under this Act. However, there never seems to have been a case. Since the $\mathrm{HC}^{37}$ hear issues of fact, there is no good legal reason why it should not hear any appeal generally;

- Appeals - Court of Admiralty of the Cinque Ports. The last case may have been in 1853 and this court has been moribund since 1914. It should be abolished, being obsolete, see Appendix $C$;

- $\quad$ Appeals - Against schemes of Church Commissioners under Pastoral Measure 1983. These are also rare. They are also anomalous since appeals against cathedral schemes cannot be made to the JCPC. There is no good legal reason why the $\mathrm{HC}$ cannot deal with them;

- $\quad$ Appeals - from Arches Court of Canterbury \& Chancery Court of York. These are very rare (the last case appears to have been in 1928). Further, they arise due to an historical anomaly. They came from the Commission of Delegates and, being prior to the court reforms of 1873 , the JCPC ended up with them. Had it been the other way round it seems clear they would have gone to the Judicial C-ee of the House of Lords (then) or to the HC. There is no good reason why the $\mathrm{HC}$ cannot hear them - to allow further appeal. Or, possibly, the CA or the SC;

- $\quad$ Prize Appeals - from BOT Admiralty Courts. As to this:

- The JCPC seems never to have heard an appeal from a BOT court in respect of a case of prize. There is no good reason why the HC should not deal with them. Not least, because it has original jurisdiction when the BOT's do not have a separate admiralty court (and, it seems that none/very few do). ${ }^{38}$

- Also, the CA should handle prize appeals from the HC (the JCPC hears them, but has never heard one in recent times). This would remove an anomaly since - in the period 1699-1813 - the HC tussled over hearing prize matters with the Privy Council and, logically, the HC should have been accorded jurisdiction. In any case, it is the CA which hears appeals from the $\mathrm{HC}$ generally.

Finally, the chance of a prize matter occurring is remote (the last case was after World War 2 (1939-45)). Indeed, there seems to be a good case for abolishing prize law. ${ }^{39}$

- $\quad$ Sovereign. HM may refer 'any' matter to the JC for 'consideration and report'. It would be better if this were limited to any 'judicial' matter (in practice, it is) - since the JCPC is a now a court wholly separate from the general Privy

\footnotetext{
${ }^{32}$ The only material to, possibly, exclude should be that relating to the LC.

${ }^{33}$ For a detailed analysis of the JCPC, see M1, n 8, pp 18-28.

${ }^{34}$ These comprise: Anguilla, Bermuda, British Virgin Islands, Cayman Islands, Falkland Islands, Gibraltar, Monserrat, Pitcairn Islands, St Helena and dependencies, Turks \& Caicos Islands.

${ }^{35}$ These comprise the Judicial Committee Acts 1833, 1843, 1844 and 1915, the Privy Council Registrar Act 1853, Judicial Committee Amendment Act 1895 and Appellate Jurisdiction Act 1908.

${ }^{36}$ These are discussed in more detail in M1, $\mathrm{n}$ 8, pp 21-6.

${ }^{37} \mathrm{Cf}$. The Court of Session for Scotland (and the HC in Ireland) where the constituency is located there.

${ }^{38}$ The admiralty jurisdiction of colonial courts (later BOT courts) is contained in the Colonial Courts of Admiralty Act 1890 which provides that a colonial court with civil jurisdiction has admiralty jurisdiction accorded to it. It would be better if this Act were repealed (sections on vice-admiralty courts and droits of the Crown are obsolete anyway (ss 8-10) and for a Courts Act to provide that any BOT with civil jurisdiction possesses admiralty jurisdiction (and, failing civil jurisdiction, the HC shall have the same).

${ }^{39}$ See McBain, n 1, p 44-5. Also M1, p 15 (article on prize).
} 
Council. There has been no recent application to the JCPC in respect of this (the last referral appears to have been in 1958) and abolition would seem appropriate (or this jurisdiction being transferred to the SC).

In conclusion, there would seem to be a compelling case to transfer the above statutory rights of appeal to lower courts (thereby, allowing a right of appeal) or to abolish the same. A Courts Act should make provision for this.

\section{(b) Foreign Appeals}

The JCPC also hears appeals from a few BOT. ${ }^{40}$ Also, from some foreign countries which, formerly, comprised Empire countries, some of which are, now, part of the Commonwealth and some of which are not, viz.

- Commonwealth: Antigua \& Barbuda, Bahamas, Belize, Cook Islands \& Niue (associated States of NZ), Grenada, Jamaica, St Christopher \& Nevis, St Lucia, St Vincent \& the Grenadines, Tuvalu;

- $\quad$ Republics \& Appeals to local Head of State: Trinidad \& Tobago, Dominica, Kiribati, Mauritius, Brunei (the latter an appeal to a local head of State); ${ }^{41}$

- $\quad$ Crown Dependencies \& Sovereign Base Areas ('SBA'): Jersey, Guernsey, Isle of Man and SBA's of Akrotiri and Dhekelia in Cyprus.

Today, appeals are few and they tend to come from a very limited number of countries, especially Caribbean countries - albeit there is now a Caribbean Court of Justice which was established for this purpose and in respect of which appeals are now made to from various jurisdictions which otherwise appealed to the JCPC (e.g. Barbados, Belize, Dominica, Guyana).

\section{(c) Conclusion}

In 1871, Hatherly LC sought to amalgamate the JCPC and the House of Lords (now the SC). A unified court was also the wish of Lords Brougham, Westbury, Selbourne, Cairns and Campbell. ${ }^{42}$ In hindsight they were correct since such would have streamlined the court system and reduced delays and bureaucracy. It is asserted that the JCPC should be abolished ${ }^{43}$ - which would remove the antiquated Victorian legislation governing it. Would anyone complain? ${ }^{44}$

\section{In conclusion, the JCPC should be abolished.}

\section{COURT MARTIAL COURT OF APPEAL}

\section{(a) Statutory Constitution}

The CMAC was established in 1951 by the Court Martial (Appeals) Act 1951 which Act was replaced by one similarly entitled in $1968 .{ }^{45}$ The CMAC is a court of record and it hears appeals from courts martial in respect of the armed forces (the army, navy, air force). The Court Martial (Appeals) Act 1968 contains the following sections:

$$
\begin{aligned}
& \text { The CMAC; }{ }^{46} \\
& \text { Appeals from the court martial; }{ }^{47} \\
& \text { Disposal of appeal; }{ }^{48}
\end{aligned}
$$

\footnotetext{
${ }^{40}$ In 2019, it heard 37 cases; however 22 were from just three places: Trinidad \& Tobago, BVI and the Bahamas.

${ }^{41}$ The JCPC does not issue a judgment as such; only an opinion to the Sultan of Brunei, see M1, n 8. p 20, n 29.

${ }^{42}$ See M1, n 8, p 26.

${ }^{43}$ An article in 2013 (see M1, n 8) proposed merging the courts (i.e. 'the SC shall sit as the JCPC as and when required'). However, the number of appeals from foreign countries has continued to decline and there is now a Caribbean Court of Justice. Thus, it would seem best to abolish the JCPC, which would get rid of old legislation.

${ }^{44}$ In the case of statutory appeals, surely not ? In the case of other appeals, SC judges try the matter anyway. Would there be any problems arising of abolition? Not in the case of BOT, Crown dependencies and sovereign base areas since the Crown can allocate jurisdiction to such court as it chooses. In the case of Commonwealth countries and republics who presently refer to the JCPC - doubtless - they could accept (or reject) any transfer of jurisdiction to the SC (one supposes most would treat this as a minor matter of procedural allocation since SC judges hear the appeal anyway).

${ }^{45}$ The 1951 Act still contains the following ss: 29 (appointment of judge advocate general, 'JAG'), 30 (assistants to JAG), 31 (qualifications of JAG and assistants), 32 (tenure of office of JAG and assistants), 33 (salaries of JAG and assistants), 35 (pensions of assistants to JAG). These should be placed in a schedule to a Courts Act.

${ }^{46} \mathrm{~S} 1$ (the court and its jurisdiction), 2 (judges), 3 (other senior judges who may exercise the powers of an appeal court), 4 (sittings), 6 (power of MR to act for the CJ), 7 (court staff, salaries and pensions).

${ }^{47} \mathrm{~S} 8$ (right of appeal), 9 (application for leave to appeal), 11 (consideration of application by appeal court).

${ }^{48} \mathrm{~S} 12$ (power to quash conviction as unsafe), 13 (power to re-sentence when some but not all convictions successfully appealed), 14 (substitution of conviction on different charge otherwise than after guilty plea), 14A (substitution of conviction on different charge after guilty plea), 16 (substitution of finding of insanity or findings of unfitness to stand trial etc), 16A (appeals against sentence), 17 (term of sentence passed under s 13, 14, 14A or 16A), 17A (appeals by civilians: application of Service Act provisions).
} 


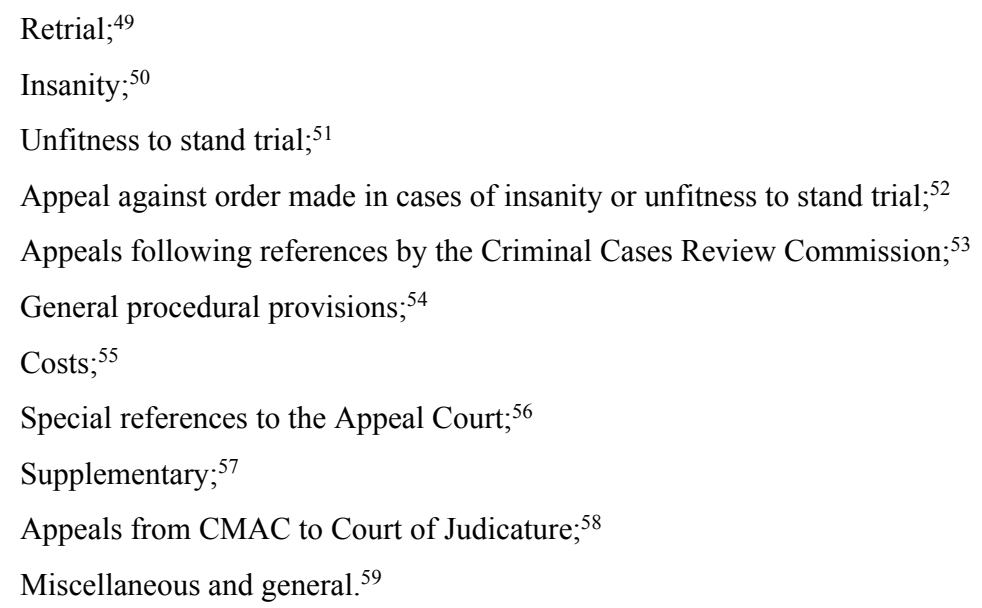

\section{(b) $\underline{\text { Conclusion }}$}

There are only a handful of successful appeals made to the CMAC every year. ${ }^{60}$ Thus, this court should be merged into the CA. Such will further integrate military and civilian law as well as ensure the application of impartial justice to the greatest extent possible. Further, the small (tiny) number of cases militates against the need for a separate court. And, the cumbrous mechanisms laid down in the Court Martial (Appeals) Act 1968 results in delay, costs and bureaucracy. It may, also, be noted that the wording of the 1968 Act is somewhat dated (e.g. provisions relating to insanity and unfitness to stand trial should reflect modern general law).

In conclusion, the CMAC should become part of the CA. The 1951 and 1968 Acts should be repealed and the provisions of the 1968 Act should be re-formed into CA rules of court, where required.

\section{COURT OF APPEAL}

\section{(a) Constitution - CA}

The CA is regulated by the Senior Courts Act 1981 which categorises it as a 'senior court. ${ }^{61}$ The 1981 Act, s 2 (The Court of Appeal) states:

(1) The [CA] shall consist of - (a) ex-officio judges, and (b) ordinary judges, of whom the maximum full-time equivalent number is 39 .

(2) The following shall be ex-officio judges of the [CA]...

(b) any person who was [LC] before 12 June 2003; (spent)

\footnotetext{
${ }^{49} \mathrm{~S} 19$ (power to authorise retrial in certain cases), 20 (implementation of authority for retrial and supplementary orders of appeal court).

${ }^{50} \mathrm{~S} 21$ (appeal against finding of not guilty by reason of insanity), 22 (consequences where appeal under s 21 allowed), 23A (substitution of finding of not guilty).

${ }^{51} \mathrm{~S} 24$ (appeal against finding of unfitness), 25 (disposal of appeal under s 24).

${ }^{52} \mathrm{~S} 25 \mathrm{~A}$ (right of appeal against hospital order etc), 25B (disposal of appeal under s 25A).

${ }^{53} \mathrm{~S} 25 \mathrm{C}$ (power to dismiss certain appeals following references by the CCRC).

${ }^{54} \mathrm{~S} 27$ (right of appellant to be present), 28 (evidence), 29 (power to call for report by member of the court martial), 29A (power to order investigation by Criminal Cases Review Commission), 30 (other powers for facilitating the disposal of an appeal).

${ }^{55} \mathrm{~S} 31$ (costs of successful appeal), 31 A (legal costs), 32 (costs against appellant), 33 (witnesses' expenses), 33A (appellant's expenses), 33B (further provision about costs), 33C (regulations).

${ }^{56} \mathrm{~S} 34$ (reference of cases by service authorities).

${ }^{57} \mathrm{~S} 35 \mathrm{~A}$ (effect of interim hospital orders), 36 (powers under pt 2 which are exercisable by a single judge), 36A (powers under pt 2 which are exercisable by single judge), 36B (procedural directions: powers of single judge and registrar), 36C (appeals against procedural directions), 37 (provision of recorded proceedings of the court martial), 37A (false statements in computer record certificates), 38 (defence of appeals), ${ }^{58} \mathrm{~S} 39$ (right of appeal), 40 (application for leave to appeal), 41 (hearing and disposal of appeal), 42 (bail), 43 (detention of accused), 43A (continuation of community treatment order), 44 (presence of accused at hearing), 45 (effect of appeal on sentence), 46 (restitution of property), 46A (costs: application to appeal court by director of service prosecutions), 46B (costs: application to appeal court by accused), 47 (costs: application to SC), 47A (further provision about costs), 47B (regulations), 48 (powers under pt 3 which are exercisable by single judge), 48A (appeals on behalf of deceased persons).

${ }^{59} \mathrm{~S} 49$ (rules of court), 51 (duties of registrar with respect to appeals etc), 52 (removal of prisoners), 54 (saving for prerogative), 56 (modifications for protected prisoners of war), 57 (interpretation).

${ }^{60}$ See also Summary of Court Martial Appeal Court Cases. Version 1 (July 2020).

${ }^{61}$ SCA 1981, s 1 (1) (senior courts) '(1) The senior courts of England and Wales shall consist of the [CA], the [HC] and the CC, each having such jurisdiction as is conferred on it by or under this or any other Act.'
} 
(c) any judge of the [SC] who at the date of his appointment was, or was qualified for appointment as, an ordinary judge of the [CA] or held an office within [paras] (d) to (g)

(d) the $[\mathrm{CJ}]$;

(e) the $[\mathrm{MR}]$;

(f) the President of the Queen's Bench Division;

(g) the President of the Family Division;

(h) the Chancellor of the $[\mathrm{HC}]$.

but a person within [paras] (b) or (c) shall not be required to sit and act as a judge of the [CA] unless at the request of the

$[\mathrm{CJ}]$ he consents to do so.

(2A) The [CJ] may nominate a judicial office holder (as defined in [s] 109(4) of the Constitutional Reform Act 2005) to exercise his function under [ss] (2) of making requests to persons within [paras] b) and (c) of that [ss].

(3) An ordinary judge of the [CA] (including the [V-P], if any, of either division) shall be styled "Lord Justice of Appeal" or "Lady Justice of Appeal".

(4) $[\mathrm{HM}]$ may by Order in Council from time to time amend [ss] (1) so as to increase or further increase the maximum full-time equivalent number of ordinary judges of the $[\mathrm{CA}]$.

(4A) It is for the [LC] to recommend to [HM] the making of an Order under [ss] (4).

(5) No recommendation shall be made to [HM] in Council to make an Order under [ss] unless a draft of the Order has been laid before Parliament and approved by resolution of each House of Parliament.

(6) The [CA] shall be taken to be duly constituted notwithstanding any vacancy in the office of [CJ], [MR], President of the [QBD], President of the Family Division or Chancellor of the [HC].

(7) For the purposes of this [s] the full-time equivalent number of ordinary judges is to be calculated by taking the number of fulltime ordinary judges and adding, for each ordinary judge who is not a full-time ordinary judge, such fraction as is reasonable.

As may be seen (see 4(a)), these provisions are similar to those relating to the SC, mutatis mutandis. Thus, a Courts Act should combine them. The term 'senior court' is not needed in a Courts Act.

\section{(b) Divisions of the CA - Criminal \& Civil}

The $\mathrm{CA}$ is divided into 2 divisions. A criminal division headed by the $\mathrm{CJ}$ and a civil division headed by the Master of the Rolls (the 'MR'). Thus, the 1981 Act, s 3 (divisions of the CA) states:

(1) There shall be two divisions of the [CA], namely the criminal division and the civil division.

(2) The [CJ] shall be president of the criminal division of the [CA], and the [MR] shall be president of the civil division of that court.

(3) The [CJ] may, after consulting the [LC], appoint one of the ordinary judges of the [CA] as vice-president ('V-P') of both divisions of that court, or one of those judges as [VP] of the criminal division and another of them as [VP] of the civil division.

(4) When sitting in a court of either division of the [CA] in which no ex-officio judge of the [CA] is sitting, the [VP] (if any) of that division shall preside.

(5) Any number of courts of either division of the [CA] may sit at the same time.

(6) The [LCJ] may nominate a judicial office holder (as defined in [s] 109(4) of the Constitutional Reform Act 2005) to exercise his functions under [ss] (3).

This section should be set out in a Courts Act. The 1981 Act also makes provision as to the distribution of business between the 2 divisions. Thus, s 53 (distribution of business between civil and criminal divisions) states:

(1) Rules of court may provide for the distribution of business in the [CA] between the civil and criminal divisions, but subject to any such rules business shall be distributed in accordance with the following provisions of this [s].

(2) The criminal division of the $[\mathrm{CA}]$ shall exercise:

(a) all jurisdiction of the [CA] under [pts 1 \& 2] of the Criminal Appeal Act 1968; 
(b) the jurisdiction of the [CA] under [s] 13 of the Administration of Justice Act 1960 (appeals in cases of contempt of court) in relation to appeals from orders and decisions of the Crown Court;

(c) all other jurisdiction expressly conferred on that division by this or any other Act; and

(d) the jurisdiction to order the issue of writs of venire de novo.

(3) The civil division of the [CA] shall exercise the whole of the jurisdiction of that court not exercisable by the criminal division.

(4) Where any class of proceedings in the [CA] is by any statutory provision assigned to the criminal division of that court, rules of court may provide for any enactment relating to -

(a) appeals to the [CA] under [pt 1] of the Criminal Appeal Act 1968; or

(b) any matter connected with or arising out of such appeals,

to apply in relation to proceedings of that class or, as the case may be, to any corresponding matter connected with or arising out of such proceedings, as it applies in relation to such appeals or, as the case may be, to the relevant matter within [para] (b), with or without prescribed modifications in either case.

The 1981 Act also contains the following sections relating to the CA:

$\begin{array}{ll}\text { Court of Civil division } & \text { (s 54) } \\ \text { Court of Criminal Division } & \text { (s 55) } \\ \text { Judges not to sit on appeal from their own judgments etc } & \text { (s 56) } \\ \text { Circuit judges not to sit on certain appeals } & \text { (s 56A) } \\ \text { Allocation of cases in criminal division } & \text { (s 56B) } \\ \text { Sittings and vacations } & \text { (s 57) } \\ \text { Calling into question of incidental decisions in civil division } & \text { (s 58) } \\ \text { Form of judgment of court of criminal division } & \text { (s 59) } \\ \text { Rules of court and decisions of CA as to whether judgment or order is final } & \\ \text { or interlocutory } & \text { (s 60) }\end{array}$

Further, the Access to Justice Act 1999 contains sections on: the composition of the civil division of the CA (s 59) and the calling into question of incidental questions (s 60).

The above material shall be set out in a schedule to a Courts Act.

\section{(c) Jurisdiction of the CA}

The 1981 Act, 15 (general jurisdiction of $C A$ ) states:

(1) The $[\mathrm{CA}]$ shall be a superior court of record.

(2) Subject to the provisions of this Act, there shall be exercisable by the [CA] -

(a) all such jurisdiction (whether civil or criminal) as is conferred on it by this or any other Act; and

(b) all such other jurisdiction (whether civil or criminal) as was exercisable by it immediately before the

commencement of this Act.

(3) For all purposes of or incidental to -

(a) the hearing and determination of any appeal to the civil division of the [CA]; and

(b) the amendment, execution and enforcement of any judgment or order made on such an appeal,

the [CA] shall have all the authority and jurisdiction of the court or tribunal from which the appeal was brought.

(4) It is hereby declared that any provision in this or any other Act which authorises or requires the taking of any steps for the execution or enforcement of a judgment or order of the $[\mathrm{HC}]$ applies in relation to a judgment or order of the civil division of the $[\mathrm{CA}]$ as it applies in relation to a judgment or order of the $[\mathrm{HC}]$.

The 1981 Act, s 16 (appeals from the HC) states:

(1) Subject as otherwise provided by this or any other Act (and in particular to the provision in [s] n 13(2)(a) of the Administration of Justice Act 1969 excluding appeals to the [CA] in cases where leave to appeal from the [HC] directly to the [SC] is granted under Part II of that Act), or as provided by any order made by the [LC] under [s] 56(1) of the Access to Justice Act 1999, or as

\footnotetext{
${ }^{62}$ This should be - for all of the SC, CA and HC - in rules of court, for easier amendment.
} 
provided by any order made by the [LC] under [s] 56(1) of the Access to Justice Act 1999, the [CA] shall have jurisdiction to hear and determine appeals from any judgment or order of the $[\mathrm{HC}] .^{63}$

[(2) An appeal from a judgment or order of the [HC] when acting as a prize court shall not be to the [CA], but shall be to [HM] in Council in accordance with the Prize Acts 1864 to 1944.] ${ }^{64}$

There are also sections relating to: applications for a new trial (s 17) and restrictions on appeals to the CA (s 18). Other legislation governing appeals to the CA is the Criminal Appeal Act 1968. It contains sections on appeal to the CA in criminal cases (ss 1-32). It is also possible for the CA to hear appeals otherwise than as statutorily provided. Thus, the Access to Justice Act 1999, s 55 (second appeals) states:

(1) Where an appeal is made to the county court, the family court or the [HC] in relation to any matter, and on hearing the appeal the court makes a decision in relation to that matter, no appeal may be made to the [CA] from that decision unless the [CA] considers that -

(a) the appeal would raise an important point of principle or practice, or

(b) there is some other compelling reason for the $[\mathrm{CA}]$ to hear it.

(2) This section does not apply in relation to an appeal in a criminal cause or matter.

Also, s 57 (assignment of appeals to $C A$ ) states:

(1) Where in any proceedings in the county court, the family court or the [HC] a person appeals, or seeks permission to appeal, to a court other than the [CA] or the [SC] - (a) the [MR], or b) the court from which or to which the appeal is made, or from which permission to appeal is sought, or (c) the President of the Family Division where it is the family court from which or to which the appeal is made, or from which permission to appeal is sought, may direct that the appeal shall be heard instead by the [CA]. (2) The power conferred by [ss] (1)(b) shall be subject to rules of court.

In this Act, there are also sections relating to: permission to appeal in rules of court (s 54) and the power of the $\mathrm{LC}$ to prescribe an alternative destination of appeals (s 56).

This material should be set out in a Courts Act.

\section{(d) Conclusion}

Legislation on the CA should be set out in a Courts Act - aligned with that in respect of the SC and the HC. Further, the opportunity should be taken to simplify matters of jurisdiction. Thus, the SC and CA should both have plenary civil and criminal appellate jurisdiction viz. the:

- $\quad \mathrm{SC}$ to have jurisdiction to hear: (i) all civil and criminal appeals from the CA; and (ii) limited civil and criminal appeals from the HC (leapfrogging).

- $\quad$ CA to hear all civil and criminal appeals from the HC save where statutory exceptions are made.

More particularly, to cut down the current (huge) backlog of cases, consideration should be given as to a Courts Act providing that all appeals from County, Family and Magistrates' courts should now go direct to the CA, obviating the HC (cf. s 56 and 57 above).

In conclusion, material on the CA should be consolidated in a Courts Act.

\section{HIGH COURT}

\section{(a) Constitution - HC}

The Senior Courts Acts 1981, s 4 (the High Court) states:

(1) The $[\mathrm{HC}]$ shall consist of -

(b) the $[\mathrm{CJ}]$;

(ba) the President of the $[\mathrm{QBD}]$;

(c) the President of the Family Division;

(d) the Chancellor of the $[\mathrm{HC}]$;

(dd) the Senior Presiding Judge;

(ddd) the vice-president of the [QBD]; and

(e) the puisne judges of that court, of whom the maximum full-time equivalent number is 108 .

\footnotetext{
${ }^{63}$ This provides for direct appeals to the $\mathrm{SC}$ from the HC (leap frogging).

${ }^{64}$ See $\mathrm{n} 39$.
} 
(2) The puisne judges of the $[\mathrm{HC}]$ shall be styled "Justices of the High Court".

(3) All the judges of the [HC] shall, except where this Act expressly provides otherwise, have in all respects equal power, authority and jurisdiction.

(4) $[\mathrm{HM}]$ may by Order in Council from time to time amend [ss] (1) so as to increase or further increase the maximum full-time equivalent number of puisne judges of the $[\mathrm{HC}]$.

(4A) It is for the [LC] to recommend to [HM] the making of an Order under [ss] (4).

(5) No recommendation shall be made to [HM] in Council to make an Order under [ss] (4) unless a draft of the Order has been laid before Parliament and approved by resolution of each House of Parliament.

(6) The High Court shall be taken to be duly constituted notwithstanding any vacancy in the office of the [CJ], President of the QBD, President of the Family Division, Chancellor of the [HC] or Senior Presiding Judge and whether or not an appointment has been made to the office of [VP] of the [QBD].

(7) For the purposes of this section the full-time equivalent number of puisne judges is to be calculated by taking the number of full-time puisne judges and adding, for each puisne judge who is not a full-time puisne judge, such fraction as is reasonable

This material on the HC is very similar to that in relation to the SC (see 4(a) and the CA (see 7(a)). Thus, it should be synchronised with such. Further, the term 'puisne judge' should be replaced with that of an 'ordinary' judge.

\section{(b) Divisions of the HC}

The 1981 Act, s 5 (divisions of High Court) states:

(1) There shall be three divisions of the $[\mathrm{HC}]$ namely:

(a) the Chancery Division, consisting of the Chancellor of the [HC], who shall be president thereof, and such of the puisne judges as are for the time being attached thereto in accordance with this [s];

(b) the $[\mathrm{QBD}]$, consisting of the $[\mathrm{CJ}]$, the President of the [QBD], the vice-president of the [QBD] and such of the puisne judges as are for the time being so attached thereto; and

(c) the Family Division, consisting of the President of the Family Division and such of the puisne judges as are for the time being so attached thereto.

(2) The puisne judges of the $[\mathrm{HC}]$ shall be attached to the various Divisions by direction given by the $[\mathrm{CJ}]$ after consulting the [LC]; and any such judge may with his consent be transferred from one Division to another by direction given by the [CJ] after consulting the [LC], but shall be so transferred only with the concurrence of the senior judge of the Division from which it is proposed to transfer him.

(3) Any judge attached to any Division may act as an additional judge of any other Division at the request of the [CJ] made with the concurrence of both of the following:

(a) the senior judge of the Division to which the judge is attached;

(b) the senior judge of the Division of which the judge is to act as an additional judge.

(4) Nothing in this [s] shall be taken to prevent a judge of any Division (whether nominated under [s] 6(2) or not) from sitting, whenever required, in a divisional court of another Division or for any judge of another Division.

(5) Without prejudice to the provisions of this Act relating to the distribution of business in the High Court, all jurisdiction vested in the $[\mathrm{HC}]$ under this Act shall belong to all the Divisions alike.

(6) The [CJ] may nominate a judicial office holder (as defined in section 109(4) of the Constitutional Reform Act 2005) to exercise his functions under [ss] (2).

The 1981 Act also contains sections 6 and 7 relating to the following matters:

- $\quad$ Patents, Admiralty and Commercial Courts. (1) There shall be - (a) as part of the Chancery Division, a Patents Court; and (b) as parts of the [QBD], an Admiralty Court and a Commercial Court. (2) The judges of the Patents Court, of the Admiralty Court and of the Commercial Court shall be such of the puisne judges of the [HC] as the [CJ] may, after consulting the [LC], from time to time nominate to be judges of the Patents Court, Admiralty Judges and Commercial judges respectively. (3) The [CJ] may nominate a judicial office holder (as defined in [s] 109(4) of the Constitutional Reform Act 2005) to exercise his functions under [ss] (2). 
- Power to alter Divisions or transfer certain courts to different Divisions. (1) [HM] may from time to time, on a recommendation of the [LC] and the judges mentioned in [ss] (2), by Order in Council direct that - (a) any increase or reduction in the number of Divisions of the [HC]; or (b) the transfer of any of the courts mentioned in [s] 6(1) to a different Division, be carried into effect in pursuance of the recommendation. (2) Those judges are the [CJ], the [MR], the President of the [QBD], the President of the Family Division and the Chancellor of the [HC]. (3) An Order in Council under this [s] may include such incidental, supplementary or consequential provisions as appear to $[\mathrm{HM}]$ necessary or expedient, including amendments of provisions referring to particular Divisions contained in this Act or any other statutory provision. (4) Any Order in Council under this [s] shall be subject to annulment in pursuance of a resolution of either House of Parliament. ${ }^{65}$

The 1981 Act, s 66 (divisional courts of the HC) also states:

(1) Divisional courts may be held for the transaction of any business in the [HC] which is, by or by virtue of rules of court or any other statutory provision, required to be heard by a divisional court. (2) Any number of divisional courts may sit at the same time. (3) A divisional court shall be constituted of not less than two judges. (4) Every judge of the [HC] shall be qualified to sit in any divisional court. (5) The judge who is, according to the order of precedence under this Act, the senior of the judges constituting a divisional court shall be the president of the court.

The present 'divisions' of the HC derived from history, rather than practicality. Thus, it would seem better (and more administratively useful) to abolish these civil 'divisions' (QBD, Chancery, Family) and, instead, refer to the actual courts of the HC. At present, there seem to be 9:

$\begin{array}{lll}\text { Family Court } & \text { Admiralty Court } & \text { Commercial Court } \\ \text { Administrative Court } & \text { Technology and Construction Court } & \text { Bankruptcy Court } \\ \text { Companies Court } & \text { Patents Court } & \end{array}$

More particularly, there would seem to be a (good) case for merging the Crown Court (CC) into the HC. Thus, there would be one $\mathrm{HC}$ with 2 divisions - the criminal and the civil. This would be much more intelligible to everyone. If so, the above material in the 1981 Act would be unnecessary - save as to the ability to move HC judges between $\mathrm{HC}$ courts.

\section{(c) Jurisdiction of the $\mathrm{HC}$}

The 1981 Act, s 19 (general jurisdiction of the HC), states:

(1) The $[\mathrm{HC}]$ shall be a superior court of record. (2) Subject to the provisions of this Act, there shall be exercisable by the [HC] (a) all such jurisdiction (whether civil or criminal) as is conferred on it by this or any other Act; and (b) all such other jurisdiction (whether civil or criminal) as was exercisable by it immediately before the commencement of this Act (including jurisdiction conferred on a judge of the $[\mathrm{HC}]$ by any statutory provision). (3) Any jurisdiction of the [HC] shall be exercised only by a single judge of that court, except in so far as it is - (a) by or by virtue of rules of court or any other statutory provision required to be exercised by a divisional court; or (b) by rules of court made exercisable by a master, registrar or other officer of the court, or by any other person. (4) The specific mention elsewhere in this Act of any jurisdiction covered by [ss] (2) shall not derogate from the generality of that $[\mathrm{ss}]$.

This section is not at all clear. If obsolete courts were abolished ${ }^{67}$ - and the CC merged with the $\mathrm{HC}$ - then it would be possible to state that the $\mathrm{HC}$ has plenary original criminal and civil jurisdiction save where legislation provides otherwise (i.e. in respect of county courts, magistrates' courts and tribunals). As it is, the 1981 Act, then, stipulates more specific jurisdiction as follows:

- Admiralty jurisdiction ${ }^{68}$

- Other particular fields of jurisdiction ${ }^{69}$

This material on the jurisdiction of the HC should be inserted into a Courts Act (in a schedule where it relates to specific courts).

\footnotetext{
${ }^{65}$ See also the AJA 1970, s 1 (re-distribution of business among divisions of the HC) and 10 (temporary additional judges in the patents and registered design appeal tribunals).

${ }^{66}$ Consideration should be given to expanding this to become a Transport Court.

${ }^{67}$ If abolished, the jurisdiction of all other courts then existing is statutory.

${ }^{68} \mathrm{~S} 20$ (admiralty jurisdiction of the HC), 21 (mode of exercise of admiralty jurisdiction), 22 (restrictions on entertainment of actions in personam in collision and other similar cases), 23 (HC not to have jurisdiction in cases with the Rhine Convention), 24 (supplementary provisions as to admiralty jurisdiction).

${ }^{69} \mathrm{~s} 25$ (probate jurisdiction of $\mathrm{HC}$ ), 26 (matrimonial jurisdiction of $\mathrm{HC}$ ), 27 (prize jurisdiction of the HC), 28 (appeals from CC and inferior courts), 28A (proceedings on case stated by magistrates' court or CC), 29 (mandatory, prohibiting and quashing orders), 30 (injunctions to restrain persons from acting in offices in which they are not entitled to act), 31 (application for judicial review), 31A (transfer of judicial review applications to upper tribunal).
} 


\section{(d) Powers of the HC}

The 1981 Act also specifies various powers of the HC, viz.

- $\quad$ powers (ss $32-43 \mathrm{~A}) ;^{70}$

- $\quad$ extraordinary functions of the judges (s 45$).^{71}$

This material should be inserted into a Courts Act. ${ }^{72}$ The Administration of Justice Act 1985 also contains various powers of the $\mathrm{HC}$ viz. the power of the $\mathrm{HC}$ :

- $\quad$ to make judgments binding on persons who are not parties (s 47)

- $\quad$ to authorise action to be taken in reliance on counsel's opinion (s 48)

- $\quad$ on the compromise of a probate action (s 49)

- $\quad$ to appoint a substitute for (or to remove) a personal representative (s 50).

The AJA 1969, s 21 also provides for the HC to have certain powers prior to the commencement of an action.

This material on the powers of the HC should be inserted into a Courts Act.

\section{(e) Business of the $\mathrm{HC}$}

The 1981 Act also contains the following sections:

- $\quad$ Business of the $\mathbf{H C}$, viz. ss 61 (distribution of business among divisions), 62 (business, admiralty and commercial courts), 63 (business assigned to specially nominated judges), 64 (choice of division by plaintiff), 65 (power of transfer).

- $\quad$ Mode of conducting Business of the HC viz. s 67 (proceedings in court and in chambers), 68 (exercise of HC jurisdiction otherwise than by judges of that court), 69 (trial by jury), 71 (sittings and vacations).

This material on the business of the HC should be inserted into a Courts Act.

\section{(f) Conclusion}

The $\mathrm{HC}$ is a court created by legislation. This comprises, in the main, the 1981 Act. However, there is also material on the HC in other legislation. All this should be consolidated into a Courts Act. Further, the opportunity should be taken to modernise things. The Crown Court should merge with the HC and the HC then have only 2 divisions (like the CA) - a criminal and a civil division. This would simplify matters greatly.

In conclusion, legislation on the HC should be consolidated into one Courts Act. Further, the CC should be merged into the $\mathrm{HC}$ which should then have 2 divisions (like the CA) - criminal and civil.

\section{JUDICIAL APPOINTMENTS TO THE SC, CA and HC}

There are matters relating to the courts and judges which are in legislation. However, it would be (much) more suitable if they were placed in an SI - to permit easier amendment as well as to consolidate the same., since there is a large degree of commonality. These include matters relating to the following:

- Judicial Salaries \& Pensions. The Courts Act 1971, ${ }^{73}$ AJA Act $1973,{ }^{74}$ Judicial Pensions Act 1981, Judicial Pensions and Retirement Act 1993, the 1981 Act $^{75}$ and the City of London Courts Act $1964^{76}$ contain sections on judicial salaries and pensions.

- $\quad$ Court Fees, Costs \& Payments. The AJA $1973^{77}$ and the $2005 \mathrm{Act}^{78}$ contain sections on these.

\footnotetext{
${ }^{70} \mathrm{~s} 32$ (orders for interim payment), 32A (orders for provisional damages for personal injuries), 33 (powers of the HC exercisable before commencement of action), 34 (power of $\mathrm{HC}$ to order disclosure of documents, inspection of property etc in proceedings for personal injuries or death), 35 (provisions supplementary to ss $33 \& 34$ ), 35A (power of $\mathrm{HC}$ to award interest on debts and damages), 36 (subpoena issued by $\mathrm{HC}$ to run throughout the $\mathrm{UK}$ ), 37 (powers of $\mathrm{HC}$ with respect to injunctions and receivers), 38 (relief against forfeiture for non payment of rent), 39 (execution of instrument by person nominated by HC), 40 (attachment of debts), 40A (administrative and clerical expenses of garnishees), 41 (wards of court), 42 (restriction of vexatious legal proceedings), 43 (power of HC to vary sentence on application for quashing order), 43ZA (power of $\mathrm{HC}$ to vary committal in default), 43A (specific powers of arbitrator exercisable by $\mathrm{HC}$ ).

${ }^{71} \mathrm{~s} 44$ (extraordinary functions of judges of the $\mathrm{HC}$ ).

${ }^{72}$ There are also powers of discovery under the AJA 1970 (ss 31-5) and the AJA 1969, s 21 (photography). These should be placed in a schedule to a Courts Act. For other powers of the HC re bail, see Criminal Justice Act 1967, s 22 (see 13).

${ }^{73} \mathrm{~s} 18$ (salaries and allowances of circuit judges).

${ }^{74} \mathrm{~s} 9$ (judicial salaries), s 10 (judicial pensions increase in widow's and children's pension), s 14 (pensions of resident magistrates in NI).

${ }^{75} \mathrm{~s} 10$ (appointment), s 12 (salaries).

${ }^{76} \mathrm{~s} 7$ (remuneration and pensions of judges). In McBain, n 1, p 92 it is proposed that honorary (ceremonial) offices of Recorder of City of London and Common Serjeant be abolished. See also City of London (Courts) Act 1964, ss 12 and 15.

${ }^{77} \mathrm{~s} 16$ (application of deputy district registrars and deputy county court registrars), s 18 (payment of interpreters in criminal cases. NI).

${ }^{78}$ ss $52-3$ (fees).
} 
- $\quad$ Appointment, Tenure, Discipline, Retirement \& Removal of Judges \& Selection Process. The Courts Act 1971, ${ }^{79}$ SCA 1981 Act, ${ }^{80} 2005$ Act, ${ }^{81}$ and AJA 1973 contain sections on these. ${ }^{82}$ There are also sections in the SCA 1981 on the appointment of masters and registrars (s 89), deputies and temporary appointments (s 91), judges' clerks and secretaries (s 98).

In conclusion, the above legislation should be placed in a SI - to consolidate the same and to enable easier amendment.

\section{CROWN COURT}

\section{(a) Constitution - CC}

The 1981 Act, s 8 (The Crown Court) states:

(1) The jurisdiction of the [CC] shall be exercisable by - (a) any judge of the [HC]; or (b) any circuit judge, recorder, qualifying judge advocate or district judge (Magistrates' Courts); or (c) subject to and in accordance with the provisions of [ss] 74 and 75(2), a judge of the [HC], circuit judge, recorder or qualifying judge advocate sitting with not more than four justices of the peace ['JPs'], and any such persons when exercising the jurisdiction of the $[\mathrm{CC}]$ shall be judges of the $[\mathrm{CC}]$.

(1A) The jurisdiction of the [CC] exercisable by a qualifying judge advocate by virtue of [ss](1) is the jurisdiction of the court in relation to any criminal cause or matter other than an appeal from a youth court.

(2) A [JP] is not disqualified from acting as a judge of the [CC] merely because the proceedings are not at a place within the local justice area to which he is assigned or because the proceedings are not related to that area in any other way.

(3) When the $[\mathrm{CC}]$ sits in the City of London it shall be known as the Central Criminal Court; [and the Lord Mayor of the City and any Alderman of the City shall be entitled to sit as judges of the Central Criminal Court with any judge of the [HC], circuit judge, recorder, qualifying judge advocate or district judge (magistrates 'courts)]. ${ }^{83}$

(4) [ss] (1A) does not affect the jurisdiction of the [CC] exercisable by a person who holds an office mentioned in [ss] (1)(a) or (b) where that person is also a qualifying judge advocate.

As indicated in $\mathbf{8}$ (relating to the HC), it is suggested that the $\mathrm{CC}$ be merged with the HC. Thus, it would comprise a HC, Criminal court. This would streamline the court system and enable the HC to have plenary original jurisdiction - save where the county court, magistrates' court or tribunals have the same.

\section{(b) Jurisdiction - CC}

The 1981 Act, s 45 (General Jurisdiction of CC) states:

(1) The $[\mathrm{CC}]$ shall be a superior court of record.

(2) Subject to the provisions of this Act, there shall be exercisable by the [CC] - (a) all such appellate and other jurisdiction as is conferred on it by or under this or any other Act; and (b) all such other jurisdiction as was exercisable by it immediately before the commencement of this Act.

(3) Without prejudice to [ss] (2), the jurisdiction of the [CC] shall include all such powers and duties as were exercisable or fell to be performed by it immediately before the commencement of this Act.

(4) Subject to [s] 8 of the Criminal Procedure (Attendance of Witnesses) Act 1965 (substitution in criminal cases of procedure in that Act for procedure by way of subpoena) and to any provision contained in or having effect under this Act, the [CC] shall, in relation to the attendance and examination of witnesses, any contempt of court, the enforcement of its orders and all other matters incidental to its jurisdiction, have the like powers, rights, privileges and authority as the [HC].

(5) The specific mention elsewhere in this Act of any jurisdiction covered by [ss] (2) and (3) shall not derogate from the generality of those [ss].

The 1981 Act also has the following sections on jurisdiction:

\footnotetext{
${ }^{79} \mathrm{~s} 16$ (appointment of circuit judges), 17 (retirement, removal and disqualifiction of circuit judge).

${ }^{80} \mathrm{~s} 88$ (qualification for office), 93 (status of officers for purposes of pensions).

${ }^{81}$ ss 25-31 (appointment), 32-7 (terms of appointment), ss 38-9 (acting judges). Also, ss 63-107 (judicial appointments), 108-21 (judicial discipline), 123-356 (NI judicial appointments and removals), 137 (Parliamentary disqulaification), 137A (encouragement of diversity).

${ }^{82} \mathrm{~s} 12$ (retiremen of higher judiciary in event of incapacity).

${ }^{83}$ GS McBain, Liberties and Customs of the City of London - Are there any Left ? (2013) Int. Law Research, vol 2, no 1, pp 9, 52 propose that such provision is no longer appropriate since the same are not legally qualified; also, to avoid any suggestion of bias. See also Access to Justice Act 1999, s 76(1) (lord mayor and aldermen sitting as JPs)
} 
- $\quad$ Exclusive jurisdiction of Crown Court in trial on indictment. S 46(1). All proceedings on indictment shall be brought before the $[\mathrm{CC}]$. (2) The jurisdiction of the $[\mathrm{CC}]$ with respect to proceedings on indictment shall include jurisdiction in proceedings on indictment for offences wherever committed, and in particular proceedings on indictment for offences within the jurisdiction of the admiralty of England.

- Offences committed on ships and abroad. (1) [ss] 280, 281 and 282 of the Merchant Shipping Act 1995 (offences on ships and abroad by British citizens and others) apply in relation to other offences under the law of England and Wales as they apply in relation to offences under that Act or instruments under that Act.

The 1981 Act, s 48 (appeals to CC) also states:

(1) The [CC] may, in the course of hearing any appeal, correct any error or mistake in the order or judgment incorporating the decision which is the subject of the appeal.

(2) On the termination of the hearing of an appeal the $[\mathrm{CC}]$ - (a) may confirm, reverse or vary any part of the decision appealed against, including a determination not to impose a separate penalty in respect of an offence; or (b) may remit the matter with its opinion thereon to the authority whose decision is appealed against; or (c) may make such other order in the matter as the court thinks just, and by such order exercise any power which the said authority might have exercised.

(3) [ss] (2) has effect subject to any enactment relating to any such appeal which expressly limits or restricts the powers of the court on the appeal.

(4) Subject to [s] 11(6) of the Criminal Appeal Act 1995, if the appeal is against a conviction or a sentence, the preceding provisions of this $[\mathrm{s}]$ shall be construed as including power to award any punishment, whether more or less severe than that awarded by the magistrates' court whose decision is appealed against, if that is a punishment which that magistrates' court might have awarded.

(5) This [s] applies whether or not the appeal is against the whole of the decision.

(6) In this [s] "sentence" includes any order made by a court when dealing with an offender, including - (a) a hospital order under [Pt 3] of the Mental Health Act 1983, with or without a restriction order, and an interim hospital order under that Act; and (b) a recommendation for deportation made when dealing with an offender.

(7) The fact that an appeal is pending against an interim hospital order under the said Act of 1983 shall not affect the power of the magistrates' court that made it to renew or terminate the order or to deal with the appellant on its termination; and where the $[\mathrm{CC}]$ quashes such an order but does not pass any sentence or make any other order in its place the court may direct the appellant to be kept in custody or released on bail pending his being dealt with by that magistrates' court.

(8) Where the [CC] makes an interim hospital order by virtue of [ss] (2) - (a) the power of renewing or terminating the order and of dealing with the appellant on its termination shall be exercisable by the magistrates' court whose decision is appealed against and not by the [CC]; and (b) that magistrates' court shall be treated for the purposes of [s] 38(7) of the said Act of 1983] (absconding offenders) as the court that made the order.

\section{(c) Other Sections relating to the $\mathrm{CC}$}

The 1981 Act also contains the following sections in respect of the CC:

- $\quad$ composition of court - general provisions (s 73)

- $\quad$ composition of court - appeals and committals for sentence (s 74)

- distribution of business - allocation of cases according to composition of court etc (s 75)

- $\quad$ distribution of business - sending for trial; alteration of place of trial (s 76)

- distribution of business - sending for trial: date of trial (s 77)

- $\quad$ sittings (s 78)

- $\quad$ practice and procedure in connection with indictable offences and appeals (s 79)

- $\quad$ process to compel appearance (s 80)

- $\quad$ bail (s 81)

- duties of officers of CC (s 82). 
The Access to Justice Act 1999 also contains the following sections:

- $\quad$ enforcement of community orders (s 66)

- $\quad$ time limits where accused sent for trial (s 67).

\section{(d) Conclusion}

If the $\mathrm{CC}$ were to be merged with the $\mathrm{HC}$, then, its constitution would be the same as that of the HC. Further, provision could be made that the $\mathrm{HC}$ have plenary jurisdiction to hear all criminal matters at first instance save where legislation otherwise provided (such assumes obsolete courts are abolished). In short, matters could be greatly simplified.

\section{COUNTY COURT}

\section{(a) Introduction}

The county court was a Victorian statutory creation (the County Courts Act 1846). It sought to merge into county courts a collection of common law courts dealing with civil matters where the financial sum - or the legal complexity involved - was not great. Had the HC been in existence in 1846 (it was a statutory creation of 1875) it could have absorbed all these courts into its jurisdiction - with a judge of lesser standing than a HC judge dealing with them (a deputy HC judge). Sadly, such did not arise. The result, historically, has been confusion since there is no need for a county (local) court system as such. Also, the description of the judges sitting in county courts could have been simplified (to one of a 'Deputy HC judge'). Further, the description 'county' was a misnomer since the county court's legal jurisdiction was not the same as the territorial unit. Today county courts hear more minor civil cases before 3 types of judge viz:

- circuit judges (appointed to one of 7 regions of England and Wales, they sit in the CC and the county court within their particular region);

- $\quad$ fee paid judges (non salaried judges, they sit as deputy district judges, deputy circuit judges and recorders);

- district judges (the main full time judges (c. 400 of them) sitting in county courts - or district registries of the $\mathrm{HC}^{84}$ - they sit in one particular circuit).

\section{(b) Jurisdiction}

The County Courts Act 1984 was amended by the Crime and Courts Act 2013 to provide for the establishment of a single county court. Thus, s 17(1) states:

(1) There is to be a court in England and Wales, called the county court, for the purpose of exercising the jurisdiction and powers conferred on it -

(a) by or under this or any other Act, or

(b) by or under any Act, or Measure, of the National Assembly for Wales.

(2) The county court is to be a court of record and have a seal.

This change was useful in that - like the SC, CA, HC and CC - there was now one court designated the 'County Court' - albeit sitting in many places (c. 170 courts). Further, provision was made in 2014 for the financial limit in respect of which the county court might hear cases, to be raised (otherwise, many county courts were almost empty much of the time).

\section{(c) Problems with the County Court}

Problems remain with the county court for obvious reasons:

- The term 'county' court does not mean anything since the legal and administrative concepts of 'county' are not identical. Further, 'civil' court would be better since the term 'county' - as well as mis-leading - is unhelpful. That is, it does not help determine the judicial nature of the court;

- The county court should have first instance (i.e. original) jurisdiction over all civil matters - save where legislation provides otherwise. Such a statement could be enacted in legislation (simplifying things) if obsolete courts (see 14 and 15) were abolished. Thus, they should be;

- There is no rational reason to distinguish the county court from the HC save for the complexity of the case, the HC dealing with more complex matters. Simply to allocate a financial limit achieves little since the sum may be for (say) $£ 1 \mathrm{~m}$, but exceedingly simple in its legal nature.

\footnotetext{
${ }^{84}$ These comprise part of the HC sitting in various districts in England and Wales (often co-located in county courts). They deal with HC family and civil business.
} 


\section{(d) Possible Solution}

Thus, a better methodology (one excluding historical anomaly) would be for the county courts and the HC to be unified. This would simplify matters hugely.

- $\quad$ HC with Plenary Jurisdiction. It would enable there to be just one court (the HC) with plenary original (jurisdiction) over all civil matters. Thus, any civil jurisdiction of magistrates' courts should also pass to the HC; 85

- $\quad$ HC Judges \& Deputy HC Judges. It would simplify the description of the judge, useful for all litigants. Thus, there would be a $H C$ judge. And, a Deputy HC judge (i.e. no longer circuit judges or district judges - and fee paid judges would no longer be necessary);

- 120 Courts. The HC would sit in London as well as in (say) 120 courts around England and Wales. ${ }^{86}$ In 10-20 of these courts (in major cities) the judge sitting would be a HC judge permanently sitting there. In the others, the judge would be a Deputy HC judge.

- $\quad$ Allocation. Where the Deputy HC judge considers that he does not have the knowledge base (capacity) to hear the case, then, he could designate it a 'complex case'. The HC in London (or nearest local HC judge with the experience could then deal with it). As noted above, the $\mathrm{HC}$ comprises (in any case) the following courts:

$\begin{array}{lll}\text { Family Court } & \text { Admiralty } \text { Court }^{87} & \text { Commercial Court } \\ \text { Administrative Court } & \text { Technology and Construction Court } & \text { Bankruptcy Court } \\ \text { Companies Court } & \text { Patents Court } & \text { Criminal Court }^{88}\end{array}$

- $\quad$ Appeal Process. If the county courts were merged with the HC, appeal would be to the CA.

- Emphasis. To help clear the backlog, the emphasis should be - in all civil cases - on arbitration and mediation. For example, in cases of building and construction matters, it is possible to secure expert arbitrators easily. These have a better knowledge base. Legislative provision could be made for this (e.g. prior to any court process the parties must confirm that they, first, sought mediation/arbitration in any case where the damages sought are less than (say) $£ 3 \mathrm{~m}$ ).

- $\quad$ Rules of Court. Only HC rules would apply - including those for the 9 courts above. Thus, much bureaucracy could be cut out. Further the system would be much more manageable administratively.

\section{(e) Conclusion}

The present county court system is still too antiquated and does not 'mesh' well with the higher courts (SC, CA and HC). Indeed, even in 1846, county courts were not needed. The best solution would be to merge it with the HC. This would simplify things greatly and reduce the need for so many courts. It would also speed up the process of hearing, and disposing of, cases.

In short, there should be one HC hearing all civil matters. It should have only permanent HC judges (to hear more complex cases) and permanent Deputy HC judges (to hear all others). The county court should be abolished. ${ }^{89}$

\section{MAGISTRATES COURTS}

\section{(a) Introduction}

These courts handle most of the criminal work (c. 98\%) in England and Wales - the same being heard before a district judge (a professional judge) or three lay magistrates (JPs). The nature, and jurisdiction, of magistrates' courts are set out at length in the Magistrates' Courts Act 1980. However, there is, also, older material extant viz.

- $\quad$ The Magistrates' Courts (Appeals from Binding over Orders) Act 1956, s 1 provides for appeals from binding over orders.

- $\quad$ Metropolitan Magistrates Courts Act 1959, s 4 (borrowing powers of receiver).

- Justice of the Peace Act 1361 (who shall be Justices of the Peace. Their Jurisdiction over Offenders; Rioters; Barrators; They may take Surety for good Behaviour). It states: First, that in every county of England shall be assigned for the keeping of the peace, one lord, and with him three or four of the most worthy in the county, with some learned in the law, and they shall have power to restrain the offenders, rioters, and all other barators, and to pursue, arrest, take, and chastise them according their trespass or offence; and to cause them to be imprisoned and duly punished according to the law and customs of the realm, and according to that which to them shall seem best to do by their discretions and good advisement; and to take and arrest all those that they may find by

\footnotetext{
${ }^{85}$ This should happen anyway, to present a clear division between civil and criminal matters and to avoid conflicting or uncertain jurisdictions.

${ }^{86}$ In Wales, consideration, anyway, should be given to a HC being established (also, its handling all county and magistrates' court business).

${ }^{87}$ Consideration should be given to expanding this to become a Transport Court.

${ }^{88}$ This would be if the $\mathrm{CC}$ was merged with the $\mathrm{HC}$.

${ }^{89}$ This would also get rid of a bewildering number of judicial and other titles.
} 
indictment, or by suspicion, and to put them in prison; and to take of all them that be [not] of good fame, where they shall be found, sufficient surety and mainprise of their good behaviour towards the king and his people, and the other duly to punish; to the intent that the people be not by such rioters or rebels troubled nor endamaged, nor the peace blemished, nor merchants nor other passing by the highways of the realm disturbed, nor put in the peril which may happen of such offenders.' (underlining supplied)

- $\quad$ The Justice of the Peace Act 1968, s 1 (7) (appointment of justices, oaths of offices etc) states: 'It is hereby declared that any court of record having a criminal jurisdiction has, as ancillary to that jurisdiction, the power to bind over to keep the peace, and power to bind over to be of good behaviour, a person who or whose case is before the court, by requiring him to enter into his own recognisances or to find sureties or both, and committing him to prison if he does not comply...'

- Domestic Proceedings and Magistrates Courts Act 1978 (ss 1-8, 19-20A, 25-6, 28, 32, 35).

If magistrates' courts are retained (cf. (b) below), then, all the above should be consolidated into one piece of legislation. This will be helpful to everyone. The Acts of 1361 and 1968 (s 1 (7)) such can be repealed if a Courts Act confirms that magistrates' courts have power to fine and imprison. Also, to bind over:

(a) to keep the peace; or

(b) for good behaviour,

Also, that (a) and (b) apply whether a person had previously been convicted of a criminal offence or not (in old parlance, whether they are of 'good fame' or not). ${ }^{90}$

\section{(b) Need for Reform}

Magistrates' courts arose from the ancient office of magistrate (also, called a justice of the peace). Such was a person - a landowner and a person of status in medieval times - who dispensed justice when the office of acting as a judge had not become restricted to persons who were legally qualified. Also, when the legal and territorial power and jurisdiction of the Crown in England and Wales was not comprehensive. Today, non-professional magistrates are not conducive to people receiving criminal justice from persons who have demonstrated a sufficiently high degree of legal knowledge - however, worthy a magistrate might otherwise be. Thus it is suggested that the following occur:

- Merge Magistrates Courts with HC. Magistrates' courts (there are, presently, c. 161 operating) - as well as the CC - should merge with the HC. If this also happens with county courts, both the same could be located in one building. That is, the HC (with criminal and civil divisions). Such would save (much) money. It would, also, remove confusion for non-lawyers and enable people to go to just one court - the $\mathrm{HC}$;

- Key issue - Experience of the Judge. The crucial issue is not - and it has never been - the name of the court (whether magistrates' court, county court, HC or CC) but the experience of the judge. Thus, there should be 120 courts (as well as the $\mathrm{HC}$ in London) all operating as the $\mathrm{HC}$ throughout England and Wales. These should be staffed by 20 (or more) permanent $\mathrm{HC}$ court judges (handling more serious trials) - with the remainder being permanent Deputy HC judges handling all the business of JPs and district judges. In short, the circuit system should end, with HC judges sitting permanently in certain locations. Also, JPs - lacking legal qualifications - should no longer sit. Also, that the only titles be $\mathrm{HC}$ judge and Deputy HC judge;

- Criminal Jurisdiction. If there is one $\mathrm{HC}$ (instead of magistrates' courts and the $\mathrm{CC}$ ), then, problems of jurisdiction are removed - the $\mathrm{HC}$ being a criminal court (and a civil court) with plenary original criminal (and civil) jurisdiction, save where legislation provides otherwise. ${ }^{91}$

- More Expeditious Justice. If there is one HC (criminal division) handling all first instance criminal cases, then, appeal can go direct to the CA - expediting the dispensation of criminal justice greatly. Further, in a combined court there will be no need to distinguish between summary offences, those which can only be dealt with in the CC and those which are triable either way - saving administration, time, confusion, costs etc.

\footnotetext{
${ }^{90}$ The Justice of the Peace Act 1361 is now obsolete save as to whether this Act needs to be retain because it is the source of legal power of JPs to bind over for good behaviour. However the JPA 1968, s 1(7) expressly dealt with this (whether the Act is the source of the legal power to bind over whether a person is of ' good' fame or not, this Anglo-Saxon concept is irrelevant since caselaw has long established such a right. In any case, small amendment to s 1 (7) would only be required to clarify the position). See also GS McBain, Modernising the Law: Breaches of the Peace and Justices of the Peace (2015) Journal of Politics and Law, vol 8, no 3, pp 206-11. As it is, it would be more helpful to abolish the concept of 'court of record' and to lay down what it means (i.e. the power to imprison and fine). Also, to provide that all of statutory courts (SC, CA, HC, CC, county and magistrates courts) also have the power to bind over whether or not a person has previously committed a criminal offence.
}

${ }^{91}$ This would be unnecessary if all obsolete courts are abolished. 


\section{(c) $\underline{\text { Conclusion }}$}

There are too many courts. Not just obsolete courts but courts that have eventuated for historical reasons, not good legal (or business-like) reasons. Thus, the court system in the $21^{\text {st }}$ century should be rationalised - to fulfil its obligation of providing justice impartially and expeditiously. In short, there should be just 3 courts, viz.

$$
\begin{array}{ll}
\text { - } & \text { Supreme Court } \\
\text { - } & \text { Court of Appeal } \\
\text { - } & \text { High Court }
\end{array}
$$

The first two courts should be appellate. The first should take appeals from the CA and the HC (leapfrogging). The second should take appeals from the HC. A simplified system would avoid all jurisdictional problems. Further, both the $\mathrm{CA}$ and $\mathrm{HC}$ would have only 2 divisions (civil and criminal). In the case of the HC, permanent judges (i.e. HC judges and deputy $\mathrm{HC}$ judges) would handle all the business presently conducted by the CC, county court and magistrates' courts. Such a professional system would be less expensive, incur less delay and would simplify the law.

\section{OTHER LEGISLATION}

Besides the legislation previously discussed, there is a considerable volume of legislation scattered through many Acts - stretching as far back as 1825 (nearly 200 years ago) - which deals with court procedure, civil or criminal. In chronological order, this legislation comprises as follows (sections making amendments to other legislation have not been included): ${ }^{92}$

- $\quad$ Juries Act 1825. S 29 (king shall only challenge for cause).

- Judgments Act 1838. S 17 (judgment debts to carry interest), 18 (decrees and orders of courts of equity etc to have the effect of judgments).

- $\quad$ Metropolitan Police Courts Act 1840. S 13 (giving possession of deserted premises)

- Limitations of Actions and Costs Act 1842. S 1 (repeal of provision in local and personal Acts giving double and treble costs), s 3 (repeal of provision in local and personal Acts allowing general issue), s 4 (uniformity of notice of action), 5 (general limitation of actions under local or personal Acts). This material could be placed in a Courts Act.

- $\quad$ Criminal Justice Administration Act 1851. S 18 (by whom warrants to be backed in the Channel Islands).

- $\quad$ Review of Justices Decisions Act 1872. S 2 (a justice, when his decision is called in question in a superior court, may file an affidavit showing grounds of his decision without payment of fee), 3 (a court to take into consideration matters contained in an affidavit notwithstanding the non-appearance of counsel in support). Probably, these sections are no longer required.

- $\quad$ Summary Jurisdiction (Process) Act 1881. S 4 (service of process of English court in Scotland and of Scotch court in England), 5 (provision as to execution of process).

- $\quad$ Sheriffs Act 1887. A previous article on the Crown had suggested that sheriffs, being a sinecure, be abolished - in which case this Act should be repealed. ${ }^{93}$

- $\quad$ Criminal Justice Administration Act 1914. S 19 (continuous bail), 24 (declaration of law as to mode of entering into recognizance), 28 (provisions as to evidence), 40 (rules).

- $\quad$ AJA 1920. S 9-14 (reciprocal enforcement of judgments in the UK and in other parts of HM's dominions), 15 (questions of foreign law to be decided by judge). Section 15 appears to be spent.

- $\quad$ Criminal Justice Act 1925. S 28 (summary proceedings re Perjury Act 1911), 33 (procedure on charge of offence against corporation), 36 (forgery of passport), 37 (unlawful possession of pension documents), 41 (prohibition on taking photos etc in court). Sections 36 and 37 comprise crimes. Thus, they should not be included in a Justice Act.

- $\quad$ AJA 1925. S 23 (local registration of Bills of Sale Acts 1878-1882), 28 (power to revoke and vary orders).

- $\quad$ AJA (Misc. Provisions) Act 1933. S 2 (procedure for indictment of offenders), s 7 (costs in Crown proceedings), s 9 (HM in private capacity).

- $\quad$ Foreign Judgments (Reciprocal Enforcement) Act 1933. Ss 1-13.

- $\quad$ Law Reform (Misc Provisions) Act 1934. S 1 (effect of death on certain causes of action), S 3 (power of courts of record to award interest on debts and damages).

\footnotetext{
${ }^{92}$ See also Halsbury, Statutes (volumes on courts).

${ }^{93}$ See McBain, n 1, p 91 (sch 7). Also, GS McBain, Abolishing Obsolete Offices (2012) Coventry LJ, vol 17, no 2, pp 32-40.
} 
- $\quad$ AJA 1956. S 40 (effect of registration of judgments of courts outside England and Wales), 45-50 (admiralty jurisdiction and arrestment of ships in Scotland), 51 (modification of the Foreign Judgments (Reciprocal Enforcement) Act 1933), 55 (NI).

- $\quad$ AJA 1960. Ss 1-10 (appeal to SC in criminal cases), s 12 (publication of information relating to proceedings in private), 13 (contempt of court appeals), 14 (procedure on application for habeas corpus), 15 (appeal in habeas corpus proceedings), 18 (NI)).

- $\quad$ AJA 1964. S 12 (composition of juvenile courts), 19 (sheriff of greater London), 26 (Inner and Middle Temples). Section 19 is no longer required if sheriffs are abolished, see comment on the Sheriffs Act 1887 above.

- $\quad$ Criminal Justice Act 1967. S 8 (proof of criminal intent), 9 (proof by written statement), 10 (proof by formal admission), 17 (entry of verdict of not guilty by order of a judge), 20 (power of magistrates' court to commit on bail for sentence), 22 (extension of power of HC to grant, or vary, conditions of bail), 25 (restrictions on search warrants under the Obscene Publications Act 1959).

- $\quad$ AJA 1969. S 12-6 (appeals to HC from SC), 20 (orders for interim payment), 21 (powers of court exercisable before commencement of action), 34 (interpretation etc).

- $\quad$ AJA 1970. S 1 (redistribution of business among divisions of the HC), 10 (temporary additional judges), 11 (restriction on power of committal under Debtors Act 1869), 31-5 (discovery and related procedures), 36-9 (additional powers of court in actions by a mortgagee in possession), 40 (punishment for the unlawful harassment of debtors), 41 (recovery of costs awarded by JPs), s 44 (interest on judgment debts), 44A (interest on judgment debts expressed in a foreign currency), 48 (variation in rate of payments in maintenance orders registered in magistrates' court). Section 40 comprises a punishment for a crime. Thus, it should not be included in a Justice Act.

- $\quad$ Criminal Justice Act 1972. S 34 (power of constable to take drunken offender to a treatment centre), 36 (reference to CA by AG on point of law following acquittal on indictment), 46 (admissibility of written statements made outside England and Wales), 51 (execution of process between England, Wales and Scotland).

- $\quad$ AJA 1973. S 8 (extension of powers of court in action by mortgagee of a dwelling house), 9 (judicial salaries), 10 (judicial pensions), 12 (retirement of higher judiciary in event of incapacity), 14 (pensions of resident magistrates in NI), 16 (appointment of deputy district registrars of HC and deputy court registrars).

- $\quad$ Juries Act 1974. Ss 1-21.

- $\quad$ Litigants in Person Act (Costs and Expenses) 1975. S 1 (costs or expenses reasonable).

- $\quad$ AJA 1977. S 2 (determination of expenses), 3 (enforcement of maintenance orders), 4 (obligations awards and judgments expressed in a foreign currency), 7 (extent of powers of receivers and managers in respect of companies), 23 (jurisdiction of ancient courts).

- Criminal Law Act 1977. Ss 1-4 (conspiracy), 6-12A (offences relating to entering and removal of property), 15 (offences which are to become triable only summarily), 28 (penalties on summary conviction for offences triable either way), 30 (penalties - and mode of trial - for offences made triable only summarily), 31 (increase of fines for certain summary offences), 32 (other provisions as to maximum fines), 33 (penalties for offenders under the Explosive Substance Act 1883, s 3), 36 (enforcement of fines imposed on young offenders), 38A (execution in different parts of the UK of warrants for imprisonment for non-payment of fine), 38B (further provision for execution of warrants), 39 (service of summonses and citation throughout UK), 40 (transfer of fine orders), 48 (power to make rules as to furnishing of information by prosecutors in criminal proceedings), 51 (bomb hoaxes), 58 (proceedings involving persons under 17), 63 (provisions applying to Scotland). Sections 1-4, 6-12A, 33 and 51 comprise crimes or punishment for the same. Thus, they should not be included in a Justice Act.

- $\quad$ Charging Orders Act 1979. Ss 1-3A, 5.

- $\quad$ SCA 1981. Ss 2-3 (relate to CA), 4-7 (HC), 8 (CC), 9 (assistance for transaction of judicial business), 10 (appointment of senior court judge), 11 (tenure of senior court judge), 12 (salary of senior court judge), 13 (precedence of judges), 14 (power of senor court judge to act in cases relating to taxes), 15-18 (CA jurisdiction), 19-44 (HC jurisdiction and powers), 45-8 (CC jurisdiction), 49 (concurrent administration of law and equity), 50 (power to award damages as well as or in substitution for injunction or specific performance), 51-2 (costs), 53-60 (CA practice), 61-72 (HC practice), 73-83 (CC practice), 84-7 (rules of court), 88 (qualification for office), 89 (masters and registrars), 90 (official solicitor), 91 (deputies and temporary appointments), 92 (tenure of office), 93 (status of officers), 95 (property held by officers), 96-7 (central office), 98 (judges clerks and secretaries), 99-104 (district and probate registries), 105-28 (probate causes), 129 (Lords Commissioners to represent the LC), 131 (conveyancing counsel), 132 (seal, proof), 133 (enrolment of instruments etc), 134 (power of attorney pre-1971), 135 (bonds under court order), 136 (documents filed in senior courts), 137 (money paid into court), 140 (enforcement of fines), 141 (selection of judges for election petitions), 150 (admiralty jurisdiction, Channel islands).

- $\quad$ Contempt of Court Act 1981. Ss 1-20.

- $\quad$ Civil Jurisdiction and Judgments Acts 1982 (\& 1991). Ss 1-50 (and none).

- $\quad$ Criminal Justice Act 1982. Ss 27-40, 46-7 (fines) 
- $\quad$ AJA 1982. S 5 (maintenance at public expense to be taken into a/c in an assessment of damages), ss 7-13 (Scotland), 20-8 (wills), 38-48A (funds in court), 37 (county court limits). Sections on wills should not be included in a Justice Act.

- $\quad$ County Courts Act 1984. Ss 1-105.

- $\quad$ AJA 1985, Ss 9-10A (solicitors), 11-39 (licensed conveyancing), 40-3 (legal aid), 47 (power of HC to make judgments binding on persons not parties), 48 (power of HC to authorise action to be taken in reliance on counsel's opinions), 49 (power of HC on compromise of probate action), 50 (power of HC to appoint substitute or to remove personal representative), 53 (reimbursement of additional costs resulting from the death or incapacity of the presiding judge), 64 (NI, rules of court with respect to non-disclosure of evidence etc).

- $\quad$ Criminal Justice 1988. Ss 51-9 (fines), 67 (autrefois acquit and convict)

- $\quad$ Courts and Legal Services Act 1990. S 1 (allocation of business between the HC, family court and county court), 5 (witness statements), 8 (power of CA to award damages), 11 (representation in certain county courts and family court cases), 31B-C (audience rights), 53 (licensed conveyancing), 56 (administration of oaths), 57 (notaries), 58 (fee and other agreements), 60-1 (lawyers, barristers), 66 (presiding judges, circuits), 72-6 (judges), 89 (foreign lawyers), 104-7 (tying in), 115 (law reports).

- $\quad$ Criminal Justice 1991. Ss 24 (fines), 30 (rules).

- $\quad$ Criminal Appeal Act 1995. Ss 8-25 (Criminal Case Review Commission).

- $\quad$ Civil Evidence Act 1995. Ss 1-14.

- $\quad$ Arbitration Act 1996. Ss 1-106. This should be left in a separate Act.

- $\quad$ Civil Procedure Act 1997. Ss 1-5 (rules and directions), 6 (Civil Justice Council), 7-8 (court orders).

- $\quad$ Crime and Disorder Act 1998. Ss 49-52B (magistrates and CC).

- $\quad$ Access to Justice Act 1999. Ss 44, 46, 48 (barristers and solicitors), 54 (permission to appeal), 55 (second appeals), 56 (powers to prescribe alternative destination of appeals), 57 (assignment of appeals to CA), 68 (judges holding office in European or international courts), 69 (V-P of the QBD), 76 (lord mayor of London etc as JPs).

- $\quad$ Courts Act 2003. S 1-3 (maintaining court system), 7-42 (JPs), 51-7 (court security), 62 (head of civil justice), 64 (power to alter judicial titles), 66 (judges having the power of district judges), 67A-G (the execution of judicial functions by authorised persons), 68-85D (rules), 86A (criminal procedure and appeals), 92 (fees and costs), 97 (fines), 98 (register of judgments), 99 (HC writ of execution), 102 (NI).

- $\quad$ Criminal Justice Act 2003. Ss 29-30 (charging), 41 (allocation of offences), 154 (magistrates court power to imprison), 300-1 (fining defaulters).

- $\quad$ Constitutional Reform Act 2005. S 1 (rule of law), 2-17, 19 and 21 (LC), 23-60 (SC), 61 (Judicial Appointments Commission), 62 (Judicial Appointments and Conduct Ombudsman), 63-122 (judicial appointments and discipline), $123-36$ (NI judicial appointments), 137A (encouragement of diversity).

- $\quad$ Legal Services Act 2007. Ss 1-200.

- $\quad$ Tribunals, Courts and Enforcement Act 2007. This should not be included in a Courts Act at first (see below) save for ss 46-54 (judicial functions and appointments) which should be in a SI.

- $\quad$ Legal Aid, Sentencing and Punishment of Offenders Act 2012. Ss 1-43 (legal aid), 47-8, 55-60 (litigation funding and costs), 77 , 85-7 (sentencing of offenders), 91-104 (remand of children)

- $\quad$ Crime and Courts Act 2013. Ss 20 (judicial appointments), 24 (appeals re Bar), 28 (fees), 32 (films).

- $\quad$ Courts and Tribunals (Judiciary and Functions of Staff) Act 2018. S 3 (authorised court and tribunal staff).

With one or two exceptions (as noted) all of these Acts should be consolidated into two Justice Acts. The first should deal with matters of civil procedure (much of which could go in SI or rules) as well as civil legal aid and access to justice. The second should deal with the same in respect of criminal justice. Material on barristers, solicitors (including the Solicitors Act 1974), notaries (including the Notaries Acts 1801 and 1843) and legal services should be in a Lawyers and Legal Services Act. In short, 4 pieces of legislation could consolidate all material relating to the:

- $\quad$ Courts (a Courts Act)

- $\quad$ Civil justice (a Civil Justice Act)

- Criminal justice (a Criminal Justice Act)

- Lawyers and legal services (a Lawyers and Legal Services Act).

Once a Courts Act is in place, legislation on Tribunals could be added to the same. 


\section{PARLIAMENT ACTING AS A COURT}

\section{(a) Parliament as a Criminal or Civil Court - History}

In medieval times, Parliament acted as a court. However, even then, its jurisdiction was limited. Thus, in the period 1348-1529, the criminal process of impeachment was employed, with the House of Commons ('HC') acting in the role of accuser and the House of Lords ('HL') acting in the role of judges. ${ }^{94}$

- The persons tried were, mainly, powerful individuals who might, otherwise, have overawed (intimidated) the judges of the ordinary courts. Many of these trials were little more than political (show) trials and judgment was, often, not enforced (the accused being pardoned or fleeing abroad or being exiled).

- After a hiatus, impeachment re-commenced in 1621 but died out by 1746, when there was the last successful prosecution..$^{95}$ In all, there were c. 66 cases in the periods $1348-1459$ and $1621-1806 .{ }^{96}$

- What those impeached were accused of were 'high crimes and misdemeanors' a generic crime that was used to prosecute high treason, misconduct in a political or legal office, military incompetence, bribery etc. It was very much a political tool.

Today, the generic crime of 'high crimes and misdemeanours' has long been supplanted by distinct criminal offences, most of which are now statutory. Further, the criminal process of impeachment is long obsolete since the ordinary court legal system has proved (since 1746) sufficient. In any case there is an (almost) insuperable difficulty in respect of the resuscitation of the generic crime of high crimes and misdemeanours, and trial by Parliament, in that both the HC and HL are political - and not impartial judicial - bodies. ${ }^{97}$ Apart from the process of impeachment, the position of the HC and HL acting as a court (criminal or civil) - independently or jointly - is as follows:

- House of Commons. As long ago as 1399 the HC accepted, in a petition to the sovereign (Henry IV, 1399-1413), that they did not have criminal or civil jurisdiction - whether at first instance or appeal. ${ }^{98}$ This also seems quite clear since, from inception, the 'Commons' were summoned by the sovereign to a parliament (meeting) for political purposes. They were not qualified lawyers. Even in the $17^{\text {th }}$ century, when things were at a very low ebb between Parliament and the sovereign (James I, 1603-25), the HC accepted that it could not act, independently, to impeach a person (i.e. no original criminal jurisdiction). ${ }^{99}$ Thus, since 1621 (some 400 years ago) the position seems clear. The $\mathrm{HC}$ is not a court of law;

- $\quad$ House of Lords. The HL comprised a hereditary body of persons appointed by the sovereign in earlier times. Prior to 1693 but not after, it heard original judicial petitions in civil matters (i.e. it acted as a court of first instance). The $\mathrm{HL}$ also exercised appellate jurisdiction in respect of criminal and civil appeals. However, (excepting when the HL was involved in impeachment trials) trial was before legally qualified judges, in almost all instances. Appellate jurisdiction ended in 2009 with the establishment of the Supreme Court. ${ }^{100}$

In conclusion, there is no need for Parliament to act as a court today, given a modern, impartial, court system with various tiers of appeal. Thus, any jurisdiction of Parliament to act as a court should be abolished.

\section{(b) Peerage Claims, Imprisonment, Fines}

The HL has jurisdiction in respect of peerage claims. However, these are now (very) rare and it is appropriate that a court should deal with the same, being impartial and enabling a right of appeal. ${ }^{101}$ As to the ability to imprison and fine:

\footnotetext{
${ }^{94}$ For a detailed analysis, see GS McBain, Abolishing 'High Crimes and Misdemeanours' and the Criminal Processes of Impeachment and Attainder (2011) 85 Australian LJ, pp 871-2.

${ }^{95}$ Ibid, p 810. The last unsucessful prosecution was in 1806 (impeachment of Lord Melville).

${ }^{96}$ Ibid.

${ }^{97}$ Human Rights Act 1998, referring to Human Rights Convention, art 6.

${ }^{98}$ D Natzler \& M Hutton, Erskine May's Treatise on the Law, Privileges, Proceedings and Usage of Parliament (25th ed, 2019). See also P Evans, Essays on the History of Parliamentary Procedure (2017), p 330 referring to fn 11 (Stockdale v Hansard (1839) 112 ER 1112) 'The Commons was not a court of law in the sense recognised in the courts, and was unable to decide a matter judically in litigation between parties, either orginally or by appeal.' See also McBain, $\mathrm{n} 94, \mathrm{p} 872$.

${ }^{99}$ McBain, n 94, p 25, n 872.

${ }^{100}$ Ibid.

${ }^{101}$ Ibid. Uncontested ones tend to be dealt with by means of a report by the Attorney-General to the Crown in modern times.
} 
- House of Commons. It was asserted that the HC had (independently) the power to fine and to imprison, being a court of record. ${ }^{102}$ This claim is somewhat dubious. In any case, today, it is (effectively) otiose since the HC does not have its own prison and it has not exercised a power to fine since $1666 .{ }^{103}$ Further, there is no need for the HC to have its own prison since there has been a professional police force existing since 1829 and they are responsible for arresting people as well as (temporarily) detaining the same. The State also maintains all prisons today (private prisons - and the franchising of prisons - ended by Victorian times);

- House of Lords. The ability of the HL to imprison and to fine - unlike that of the HC - does not seem to have been challenged. However, the HL no longer maintains a prison and no longer imposes fines in practice.

In conclusion, any jurisdiction of the HL to hear peerage claims should pass to the High Court, which is more appropriate and allows an appeal. Also, any power to imprison or to fine (at common law) should also be abolished.

\section{(c) Acts of Attainder, Acts of Pains and Penalties ${ }^{104}$}

'Attainder' has two meanings. The first is to describe a type of Act (legislation) in which Parliament legislatively convicted a person of a capital crime (high treason or a felony) and imposed the punishment of the death penalty. Such was a form of criminal judgment by legislation - one in which a trial did not need to be held since the judgment of Parliament was final. ${ }^{105}$ The second meaning was to describe the extinction of civil rights resulting from the Act of Attainder. ${ }^{106}$ The last Act of Attainder in England was in 1746 (the last person executed pursuant thereto was in 1753) - more than 250 years ago.

- Although, theoretically, Acts of Attainder could still be passed by Parliament today such would be a brutum fulmen since the death penalty was abolished in 1998 (and felonies were abolished in 1967; thus, such Acts would apply to high treason only, by precedent). ${ }^{107}$ Further, the extinction of civil rights resulting from the Act of Attainder was abolished in 1870. Hence, the punishment would be non-existent.

- In any case, Acts of Attainder (legislatively putting a person to death, without an impartial trial) would be contrary to human rights legislation which requires trial by an impartial tribunal (Human Rights Convention, art 6) and the $\mathrm{HL}$ is not an impartial court (nor is the HC capable of acting as a criminal court, whether singly or jointly). Also, Acts of Attainder could be brought after a person was dead.

As it is, Acts of Attainder existed in the period 1311-1696 and, it seems, that most (c. 60\%) were reversed. While most of those attainted were accused of plotting against the sovereign (his death or deposition) other Acts of Attainder were brought to circumvent legal difficulties - whether arising from an impeachment or of an evidential nature. Acts of Attainder, also, (sadly) stand as a vivid testament to the dreadful consequences of Parliament seeking to act as a court - a baying mob of politicians seeking to do a man to death without a fair trial. They can fairly be described as a blot on British justice. In the case where a lesser penalty was sought to be imposed, legislatively, by Parliament, the Act of Attainder was replaced by an Act of Pains and Penalties. The last successful Act, in the criminal field, appears to have been in 1723, nearly 300 years ago. ${ }^{108}$ They also are otiose.

In conclusion, Acts of Attainder and Acts of Pain and Penalties should be abolished. Those still extant should be repealed as spent.

\section{(d) Conclusion}

There is no need for Parliament to act as a court - to the extent that it can. Thus, its power to do so should be abolished along with the generic crime of 'high crimes and misdemeanours', the criminal process of impeachment, the ability of Parliament to imprison or to fine (at common law) and Acts of Attainder and Acts of Pains and Penalties. Those of the latter two which still exist should be repealed as spent.

\footnotetext{
${ }^{102}$ Natzler, n 98, p 330 referring to fn 11 (Stockdale v Hansard (1839) 112 ER 1112 'The Commons was not a court of law in the sense recognised in the courts, and was unable to decide a matter judically in litigation between parties, either orginally or by appeal.' See also TE May, A Treatise upon the Law, Privileges, Proceedings and Usage of Parliament (1844), pp 71-5.

${ }^{103}$ Ibid, p 230. Also, May, n 102, p 74 (Thomas White fined $£ 1,000$ in 1666). The HC (usually) used the Tower of London or Newgate as a prison.

${ }^{104}$ See generally, McBain, n 94, pp 867-9.

${ }^{105}$ Ibid. West, A Discourse concerning Treason and Bills of Attainder (London, 1716), $\mathrm{p} 111$ (cited at p 868, n 475), put it quaintly 'when it is the act of the supreme power, whoever deserves to die, dies justly.'

${ }^{106}$ These comprised the forfeiture and escheat of the lands of the attainted person. Also, 'corruption of blood' (it prevented a person from inheriting (or holding) land or transmitting title by descent to anyone. These civil consequences were abolished by the Forfeiture Act 1870 (save in respect of outlawry, when they were abolished in 1938).

${ }^{107}$ McBain, n 94, pp 877-9.

${ }^{108} \mathrm{Ibid}, \mathrm{pp} 870-1$ (for those brought in respect of divorce, lunacy etc, see Ibid)
} 


\section{OBSOLETE COURTS}

A prior article on Modernising the Constitution - A Crown Act has advocated the abolition of the following courts. ${ }^{109}$

- courts referred to in the Administration of Justice Act 1977, sch 4, parts 1, 2 and 3 (last sat 1977);

- $\quad$ Court of the Chamberlain of the City of London (last sat more than 100 years ago);

- Court of the Duchy Chamber of Lancaster (last sat 1835);

- $\quad$ High Court of Chivalry (last sat 1737, then 1954);

- $\quad$ Cinque Ports Court of Admiralty (last sat 1914);

- Courts of the Vice-Admirals of the Coast (last sat more than 100 years ago);

- $\quad$ Court of the Lord High Steward (last sat 1686);

- $\quad$ Court of Claims (not a court as such, deals with coronation claims);

- Court of Attachment (40 Days Court) of the New Forest (last sat pre-1971 when forest law was abolished);

- Court of Attachment (40 Days Court) of the Forest of Dean (ibid);

- $\quad$ Court of the Verderers of the Forest of Dean (last sat 1902);

- Barmote courts of the High Peak and Wirksworth (last sat pre-1939);

- judicial jurisdiction of the:

(i) Royal Court of Shepway (last sat, c. 16th century);

(ii) Court of Brotherhood and Guestling (last sat c 17th, it is unclear if this was ever a judicial court as such).

For further detail on these, see Appendix B. Apart from these courts, the only other common law court that appears to exist in England and Wales is the Court of the Verderers of the Forest of Dean which sits as a magistrates' court on forest matters. However, since this court also drafts forest legislation, its judicial jurisdiction should now pass the local magistrates' court. ${ }^{110}$ In case any other ancient common law courts in England and Wales still exist, it may be apposite to abolish all of the same (as well as Parliament acting as a court, see 14). ${ }^{111}$ The only judicial bodies then existing would all be statutory - the CS, CA, CMCA, HC, CC, county court, magistrates' courts and tribunals. Such would simplify any reference to their jurisdiction.

In conclusion, all obsolete law courts should be abolished. If this is not effected in a Crown Act it should be effected in a Courts Act.

\section{COURT SYSTEM - GENERAL MATTERS}

There are various general matters relating to the court system which should be included in a Courts Act. These comprise:

\section{(a) Court Related Matters}

- Concurrent Administration of Law and Equity. The 1981 Act makes general provision for the concurrent administration of law and equity. ${ }^{112}$

\footnotetext{
${ }^{109}$ See McBain, $\mathrm{n} 1$, pp 58 \& 98.

${ }^{110}$ McBain (second article), n 9, p 208 citing The Verderers of the New Forest $v$ Young [2003] EWHC 3253 per Collins J (point 8 of his judgment) 'The court of swainmote...had some difficulties in complying with the [European Court of Human Rights] since the verderers constituted prosecutors, judges and recipients of any penalty which was imposed, and one can see that perhaps this does not measure up to modern requirements in relation to courts.'

${ }^{111}$ Such would not affect any court in the Channel Islands or BOT.

${ }^{112} \mathrm{~S} 49$ '(1) Subject to the provisions of this or any other Act, every court exercising jurisdiction in England or Wales in any civil cause or matter shall continue to administer law and equity on the basis that, wherever there is any conflict or variance between the rules of equity and the rules of the common law with reference to the same matter, the rules of equity shall prevail. (2) Every such court shall give the same effect as hitherto - (a) to all equitable estates, titles, rights, reliefs, defences and counterclaims, and to all equitable duties and liabilities; and (b) subject thereto, to all legal claims and demands and all estates, titles, rights, duties, obligations and liabilities existing by the common law or by any custom or created by any statute, and, subject to the provisions of this or any other Act, shall so exercise its jurisdiction in every cause or matter before it as to secure that, as far as possible, all matters in dispute between the parties are completely and finally determined, and all multiplicity of legal proceedings with respect to any of those matters is avoided. (3) Nothing in this Act shall affect the power of the [CA] or the $[\mathrm{HC}]$ to stay any proceedings before it, where it thinks fit to do so, either of its own motion or on the application of any person, whether or not a party to the proceedings.'
} 
- $\quad$ Central Office. The 1981 Act makes provision for a central office. ${ }^{113}$

- $\quad$ Accountant General. The 1981 Act makes provision for an accountant general. ${ }^{114}$

- $\quad$ Official Solicitor. The 1981 Act makes provision for an official solicitor. ${ }^{115}$

- Judicial Appointments Commission. The 2005 Act makes provision for such a commission. ${ }^{116}$

- Judicial Appointments and Conduct Ombudsman. The 2005 Act makes provision for such a commission. ${ }^{117}$

- District Registries and Probate registries. The 1981 Act makes provision for the same. ${ }^{118}$ These sections should be placed in a Courts Act (in the case of the last only if county and magistrates' courts are not merged into a HC).

In relation to 2 judicial offices in particular, consideration should be given whether they should be modernised:

\section{(b) Lord Chancellor (LC)}

The 2005 Act contains sections on the LC. ${ }^{119}$ Also, the Courts Act 2003, s 1(the general duty) states:

(1) The [LC] is under a duty to ensure that there is an efficient and effective system to support the carrying on of the business of

(a) the Senior Courts; (aa) the Court of Protection, (b) the county court, (ba) the family court, and (c) magistrates' courts, and that appropriate services are provided for those courts.

(2) In this Part (a) "the Senior Court" includes the district probate registries, and (b) "magistrates' court" includes a committee of justices.

(3) In this Part references to the [LC's] general duty in relation to the courts are to his duty under this [s].

(4) The [LC] must, within 18 months of the coming into force of this [s], and afterwards annually, prepare and lay before both Houses of Parliament a report as to the way in which he has discharged his general duty in relation to the courts. ${ }^{120}$

Other sections of the 2005 Act deal - in respect of the LC - with:

- qualifications for the office of the LC (s 2)

- continued judicial independence (s 3-4)

- $\quad$ representations by senior judges (ss 5-6)

- $\quad$ other provisions (12-3)

\footnotetext{
${ }^{113} \mathrm{~S} 96$ '(1) The Central Office of the Senior Courts shall perform such business as the [CJ] may, with the concurrence of the [LC], direct. (2) Subject to any direction under [ss] (1), the Central Office shall perform such business as it performed immediately before the commencement of this Act. (3) The [CJ] may nominate a judicial office holder (as defined in [s] 109(4) of the Constitutional Reform Act 2005) to exercise his functions under this [s].'

${ }^{114} \mathrm{~S} 97$ '(1) There shall continue to be an Accountant General ['AG'] of, and an accounting department for, the senior courts. (2) The [LC] shall appoint such person as he thinks fit to the office in the senior courts of [AG] of the senior courts and the person so appointed shall hold and vacate office in accordance with the terms of his appointment. (3) The [AG] shall be paid such salary or fees as the LC determines with the consent of the Treasury. (4) If one person holds office both as the [AG] and as the Public Trustee then, if he ceases to be the Public Trustee, he shall also cease to be the $[\mathrm{AG}]$ unless the $[\mathrm{LC}]$ otherwise directs. (5) If a vacancy occurs in the office of $[\mathrm{AG}]$ or the person appointed to hold the office is for any reason unable to act for any period such person as the [LC] appoints as deputy in that office shall, during the vacancy of that period, perform the functions of that office (and any property vested in the [AG] may accordingly be dealt with by the deputy in all respects as if it were vested in him instead).'

${ }^{115} \mathrm{~S} 90$ '(1) There shall continue to be an Official Solicitor ['OS'] to the senior courts, who shall be appointed by the [LC]. (2)There shall be paid to the [OS] out of money provided by Parliament such salary as the [LC] may, with the concurrence of the Minister for the Civil Service, determine. (3) The [OS] shall have such powers and perform such duties as may for the time being be conferred or imposed on the holder of that office - (a) by or under this or any other Act; or (b) by or in accordance with any direction given (before or after the commencement of this Act) by the [LC] (3A) The holder for the time being of the office of [LC] shall have the right to conduct litigation in relation to any proceedings. (3B) When acting as [OS] a person who would otherwise have the right to conduct litigation by virtue of the fact that he is a person who, for the purposes of the Legal Services Act 2007, is an authorised person in relation to an activity which constitutes the conduct of litigation (within the meaning of that Act)] shall be treated as having acquired that right solely by virtue of [ss] (3A).(4) If - (a) the [OS] is not available because of his absence or for some other reason; or (b) his office is vacant, then, during such unavailability or vacancy, any powers or duties of the [OS] shall be exercisable or fall to be performed by any person for the time being appointed by the [LC] as deputy to the $[\mathrm{OS}]$ (and any property vested in the [OS] may accordingly be dealt with by any such person in all respects as if it were vested in him instead).'

${ }^{116} \mathrm{~S} 61^{\prime}$ (1) There is to be a body corporate called the Judicial Appointments Commission. (2) Schedule 12 is about the Commission.'

${ }^{117} \mathrm{~S} 62$ '(1) There is to be a Judicial Appointments and Conduct Ombudsman. (2) Schedule 13 is about the Ombudsman.'

${ }^{118} \mathrm{~S} 99$ (district registrars), 100 (district judges), 101 (power of one district registrar to act for another), 102 (deputy district registrars), 103 (assistant district registrars), 104 (district probate registries).

${ }^{119}$ Ss 1-22.

${ }^{120}$ Other sections relate to court officers, staff and services (s 2) and to accommodation (s 3).
} 
- functions (14-6),

- $\quad$ LC's oath (17)

- $\quad$ speakership of the HL (18).

These sections should be placed in a schedule to a Courts Act. Further, the 2005 Act, s 19 makes provision for the LC to be able to transfer his (or her) functions. Given that the LC may not be a member of the Church of England ('CoE') - or, indeed, may not religious at all - it may be appropriate for the LC to transfer to the Archbishop of Canterbury (or to a person designated by the same) any CoE functions, such as any right of patronage, right to act as a visitor etc. ${ }^{121}$

\section{(c) Lord Chief Justice (CJ), Master of the Rolls (MR)}

The legal system is replete with long (and, perhaps, pompous), judicial titles. It is pertinent to ask - are they relevant in modern times? Surely, 'Chief Justice' is just as effective as 'Lord Chief Justice' and more succinct? Further, the CJ has a large number of offices and roles.

- He is head of many courts and has many titles ${ }^{122}$ - including Head of Criminal Justice. ${ }^{123}$ And, he may make many appointments, including Head of Civil Justice ${ }^{124}$ and Deputy Head of Family Justice. ${ }^{125}$

- He may nominate a judicial office holder (as defined in the Constitutional Reform Act 2005, s 109(4)) to act for him in many instances.

If the court system is reformed, it might be appropriate if the CJ only sits in the CA (as head of the criminal division) and the MR only sits in the same as head of the civil division. Then, in the HC - assuming it now comprises a criminal and a civil division - the heads of the same could exercise direct (operational) responsibility - instead of only acting as deputies - cutting out much confusion (that is not say that they would not report to the CJ generally).

In conclusion, the many ex officio offices of the CJ (and the MR) should be replaced with line responsibility, as in any corporate structure. So too, those of other judges.

\section{(d) Other Judicial Offices}

The Courts Act 2003, s 64 (power to alter judicial titles) enables the LC to alter the name of a large number of judicial offices. Also, to provide for (or alter) the way in which the holders of such offices are to be styled. Thus. s 64 refers to:

Admiralty Registrar, Chancellor of the [HC], Chief Chancery Master, Chief Insolvency and Companies Court Judge, Chief Taxing Master, Circuit judge, Deputy Circuit judge, Deputy district judge appointed under [s] 102 of the 1981 Act, Deputy district judge appointed under [s] 8 of the County Courts Act 1984, Deputy Head of Civil Justice, Deputy Head of Family Justice, Deputy judge of the $[\mathrm{HC}]$, District judge of the county court, District judge of the $[\mathrm{HC}]$, District judge of the principal registry of the Family Division, District probate registrar, Head of Civil Justice, Head of Family Justice, Insolvency and Companies Court Judge, [CJ], Master of the Chancery Division, Master of the [QBD], [MR], Ordinary judge of the [CA], President of the Courts of England and Wales, President of the Court of Protection, President of the Family Division, President of the [QBD], Presiding Judge for a Circuit, puisne judge of the $[\mathrm{HC}]$, Queen's Coroner and Attorney and Master of the Crown Office and Registrar of Criminal Appeals, Recorder, Senior District Judge of the Family Division, Senior Judge of the Court of Protection, Senior Master of the [QBD],

\footnotetext{
${ }^{121}$ Provision was made for the LC to exercise his office even if a catholic, see Lord Chancellor (Tenure of Office and Discharge of Legal Functions) Act, s 1.

1222005 Act, $\mathrm{s} 7$ (President of the Courts of England and Wales). '(1) The [CJ] holds the office of President of the Courts of England and Wales and is Head of the Judiciary of England and Wales. (2) As President of the Courts of England and Wales he is responsible: (a) for representing the views of the judiciary of England and Wales to Parliament, to the [LC] and to ministers of the Crown generally; (b) for the maintenance of appropriate arrangements for the welfare, training and guidance of the judiciary of England and Wales within the resources made available by the [LC]; (c) for the maintenance of appropriate arrangements for the deployment of the judiciary of England and Wales and the allocation of work within courts. (3) The President of the Courts of England and Wales is president of the courts listed in [ss] (4) and is entitled to sit in any of those courts. (4) The courts are - the [CA, HC, CC, family court, county court, magistrates' courts].'

${ }^{123} 2005$ Act, s 8 (Head and Deputy Head of Criminal Justice). (1) There is to be a Head of Criminal Justice. (2) The Head of Criminal Justice is - (a) the $[\mathrm{CJ}]$, or (b) if the [CJ] appoints another person, that person. (3) The [CJ] may appoint a person to be Deputy Head of Criminal Justice. (4) The [CJ] must not appoint a person under [ss] (2)(b) or (3) unless these conditions are met - (a) the [CJ] has consulted the [LC]; (b) the person to be appointed is a judge of the [CA]. (5) A person appointed under [ss] (2)(b) or (3) holds the office to which he is appointed in accordance with the terms of his appointment.'

${ }^{124}$ Courts Act 2003, s 62 (head and deputy head of civil justice). See also 2005 Act, s 8 (head and deputy head of justice), 9 (head and deputy head of family justice).

${ }^{125} 2005$ Act, s 9 .
} 
Senior Presiding Judge for England and Wales, Taxing Master of the Senior Courts, Vice-president of the [CA], Vice-president of the Court of Protection, Vice-president of the [QBD].

Even to ordinary lawyers (barristers and solicitors) such a list is confusing with a plethora of presidents and VP's. To an ordinary person it (probably) looks like a roll call from the Mikado - with the heads endlessly deputising. Who, then, actually takes responsibility? And, are judges aware how much the present legal system is out of kilter with modern corporate structures - which tend to be streamlined, flattened (i.e. they have a few tiers) and with line responsibility, in order to be business-like and to excise unnecessary bureaucracy? Suffice to say that - if the court system was rationalised into a SC, CA and $\mathrm{HC}$ - there would only need to be (perhaps) a:

- $\quad$ SC - President and Deputy President

- $\quad \mathrm{CA}$ - the CJ and MR (as heads of the criminal and civil divisions)

- $\mathrm{HC}$ - Presidents of the civil and criminal divisions.

As a result - as with any (successful) modern corporation - there would be a simple hierarchy and clear line management. Would this not be a good thing?

In conclusion, a Courts Act should make provision on various general matters.

\section{OTHER LEGAL MATTERS}

Besides the general matters referred to in 16, it would be useful for a Courts Act to deal with some other issues that will help improve the legal system. Thus:

\section{(a) Courts Buildings \& Website}

It is (manifestly) useful to users if the courts sit in one building, if possible. If the county and magistrates' courts are merged into the $\mathrm{HC}$ this would be possible (albeit, possibly, different entrances and exits). It would also reduce the costs of insurance, security, cleaning etc. However, even if not - and county and magistrates' courts remain the same should apply. Also, in this electronic age, it would be of (great) assistance to users if all courts had a website which set out, in user-friendly fashion, things such as:

- the physical location of the court;

- opening hours;

- $\quad$ access issues;

- a brief description of the court (including its history);

- reference to any general legislation, SI's and rules relating to the court;

- $\quad$ other matters that would be useful for the general public and court users, to know.

In conclusion, courts should be located in one building, where possible. Also, they should have user-friendly websites indicating what business they conduct etc.

\section{(b) Wigs \& Robes, Barristers' Fee}

Are wigs helpful? They are expensive, one more thing to carry, sometimes misplaced and they add little (or nothing) to the solemnity of a court. If retained, perhaps, they could be limited (both for judges and lawyers) to the HC, criminal court - if the CC is merged with $\mathrm{HC}$ (or, if not, to the CC). ${ }^{126}$ It would also seem useful to simplify robes and (perhaps) to dispense with ceremonial robes, summer robes, court shoes, white gloves, chains of office, other impedimenta etc. ${ }^{127}$ Also, any common law prohibition (or custom) on barristers not being able to recover their fee should be abolished.

In conclusion, the need for wigs and robes should be reviewed. Any limitation on barristers' recovering their fee should be removed.

\footnotetext{
${ }^{126}$ In recent years LC's have ditched the wig, white gloves and court shoes. Perhaps, the CJ should do the same?

${ }^{127}$ Indeed, if the court system is simplified to the SC, CA and HC, then light silk robes of different colours could be used to distinguish the judges in them, without more.
} 


\section{(c) Chief Justice's Annual Report}

The CS is required, by legislation, to issue an annual report. ${ }^{128}$ The CJ is, also, required to keep the LC and Parliament informed of his views. ${ }^{129}$ However, nowhere, is there any means by which the SC and the CJ together can present the views and recommendations of the judges of the SC, CA and HC in respect of possible technical improvements to the legal system. Thus, the LC and the Government is not well informed, for example, of the following:

- $\quad$ how the court system might be further improved, to expedite the process of justice;

- where consolidation of legislation would be useful;

- $\quad$ potentially obsolete (or spent) legislation or common law material;

- where common law material should be placed in legislation;

- $\quad$ areas of English law which should be reviewed by the Law Commission, being out of date;

- $\quad \log$ jams in the court process;

- $\quad$ where court procedure could be simplified;

- other concerns of a technical nature (security etc).

What would be useful, therefore, would be an annual combined report of the SC and the CJ (a 'Chief Justice's Report'). In preparing his report, the CJ could liaise with senior judges as well as the Head of the Law Commission.

- The intent of such a report should be to enable the simplification of a legal structure and court process that still owes much to Victorian times. Such a report could go to the LC and to Parliament (Legal Affairs Committee) so that both can keep a track of whether anything has been done to meet these concerns.

- As it is, because of the lack of such a report, so many improvements (many of them simple and cost saving) which could be made to the England and Wales legal system are never effected. Ones which (likely) no one would object to. Ones which would improve the lives of those using the legal system - as well as removing unnecessary costs, bureaucracy and wasted time.

Such is a missed opportunity which results in the legal system (often) being for judges, lawyers and users a veritable via crucis. Thus, legislation should provide for the SC and CJ to issue a combined annual report (one available to the public) setting out all technical concerns as well as suggestions for improvement. One directed to the LC and to Parliament. Such a report need not be long; nor speculative. It should get to the pith of the matter.

In conclusion, it would be useful for the CJ to issue an annual report indicating to the LC and Parliament-after discussion with judges and the Law Commission - what technical improvements could be made to the legal system, such as removing logjams, unnecessary bureaucracy etc.

\section{(d) Law Commission}

The Law Commission is a valuable organisation, established in 1965. However, it is hampered by a lack of manpower (as to legal experts) as well as funding. Thus, it only has 4 law commissioners to cover what have been the 4 basic areas of English law since the earliest times viz.
- Constitutional Law
- Criminal Law
- $\quad$ Land Law
- Commercial Law

The result is predictable. In these areas there is a huge - and growing - amount of legislation extant. Also, there is a huge amount of obsolete legislation and common law material extant. The result is a huge cost to the taxpayer as they (as well as the civil service and lawyers and business) struggle to cope with a volume of legislation, presently, of 'Gormenghast-like' proportions, viz.

- 3,000 general Acts

- $\quad 35,000 \mathrm{SI}$ 's

\footnotetext{
1282005 Act, s 127 (representations to Parliament) (A1) 'The President of the Supreme Court may lay before Parliament written representations on matters that appear to the President to be matters of importance relating to the Supreme Court or to the jurisdiction it exercises.'

${ }^{129}$ Ibid, '(1) The [CJ] of any part of the [UK] may lay before Parliament written representations on matters that appear to him to be matters of importance relating to the judiciary, or otherwise to the administration of justice, in that part of the [UK].' See also $n 122$.
} 
- $\quad 26,000$ local Acts

- 11,000 private Acts

As to why this has come about - and a solution - this is considered in 18. However, the Law Commission does not help itself in that it never provides an overview of the position on English legislation. This it could easily do by, for example, setting out in a Table all legislation extant pre-1925 (including the number of sections). If the Law Commission did so:

- it would immediately become apparent to the Law Commission - and to everyone else - that a large volume of pre1925 legislation relates to the 4 areas mentioned above; and

- it would incentivise the Law Commission to write to Government ministries and other bodies asking them to consolidate their legislation (since the Law Commission has no expertise - and no manpower - to undertake the same). ${ }^{130}$

Thus, it seems abundantly clear that the Law Commission should be given additional funding for one specific purpose. That is, to have retired judges (and ex-Law Commissioners) review obsolete law (i.e. legislation and common law) relating to the 4 areas above and to issue short reports on the same. ${ }^{131}$ Truly, it is not difficult.

In the case of local and private Acts - $90 \%$ of which are obsolete anyway - at the present rate it will take the Law Commission (on my computation) at least 200 years to deal with them. Part of the problem is that they are listed out in a Repeals Act and such an Act is (often) not a high priority in the enormous backlog of other legislation which the Government seeks to bring before Parliament. However, such can be remedied by allowing obsolete or spent local and private Acts to be listed in a SI (and not an Act) since these repeals are never contentious. Another problem is that the Law Commission never lists on its website local and private legislation still existing - when such is not difficult. It should do so - at least - every 5 years in order to help everyone.

In conclusion, consideration should be given to the CJ (in collaboration with the SC) issuing an annual report (which can be combined with that of the CJ, see above). The Law Commission should also be given funding to clear the large backlog of obsolete legislation and common law material it faces.

\section{LEGISLATION}

As noted above, the amount of general legislation is now vast. And it is continuing to grow. Such imposes a via crucis on judges, lawyers, civil servants and business. It evidences a legal system that is clinically obese and which needs a gastric band before it collapses. The solution, however, is quite simple.

\section{(a) Responsibility}

There are, are present, some 19 ministries. However, there is no legislation requiring them to take any responsibility for legislation they implement. Nor to consolidate the same. Nor even to remove obsolete legislation and common law material. Yet, it is not possible for the Ministry of Justice (MOJ) to undertake all such work for them. Further, because the Law Commission only have expertise in a few areas of law (see 17(d)) they do not issue reports on many areas of law such as military (armed forces) law, CoE law, transport law, environmental law etc. If all government ministries were required by legislation to take 'ownership' of the general legislation and SI's for which they are actually responsible - within two years - there would be a dramatic improvement (probably, a tenfold reduction in the number of SI's and much the same in the case of legislation). ${ }^{132}$

Thus, a Courts Act should require all government ministries, on their websites, to list all general legislation and SI's for which they are responsible. ${ }^{133}$ Further, they should publish the same in an annual handbook issued by each ministry. (e.g. an Environmental handbook, Armed Forces handbook etc). Such would, doubtless, be useful to their own staff as well as to all people dealing with any ministry and all lawyers involved with the same.

\section{(b) Consolidation}

The biggest problems facing the legal system are that there is:

- too much law;

\footnotetext{
${ }^{130}$ e.g. the law commissioners, usually, have no knowledge of military law, transport law, environmental law, local government law, C of E law etc.

${ }^{131}$ As to how long this would take see $\mathbf{1 8 .}$

${ }^{132}$ Large numbers of SI are spent or only a few sections. So too, pre-1925 general legislation.

${ }^{133}$ It would also be useful for such a website to list all agencies, other public bodies and high profile groups, which they fund or for which they are responsible. Also, to provide other useful data so as to enable a reader to obtain a comprehensive overview of the Ministry, how it is structured and how it operates.
} 
- $\quad$ too much obsolete law;

- $\quad$ too many courts.

The first arises, in the main, from a failure to consolidate legislation since the 1960's. Yet the following is astonishing, given that the Law Commission has been around since 1965:

- Criminal Law. All criminal legislation could be consolidated into just 4 Crime Acts dealing with:

- $\quad$ sexual crimes;

- $\quad$ crimes against the person;

- $\quad$ property and financial crimes;

- $\quad$ public order crimes,

if obsolete legislation was removed and common law crimes were placed in legislation. ${ }^{134}$ Further, as noted (see 13) all criminal procedure legislation could be placed in a Justice Act.

- Commercial Law. All commercial law could be consolidated into just 2 Commerce Acts, if:

- $\quad$ obsolete legislation; ${ }^{135}$ and

- common law material, ${ }^{136}$

was repealed/abolished;

- $\quad$ Land Law. All law in relation to land could be placed in one or more of the following, a:

- $\quad$ Land Law Act;

- Landlord and Tenant Act;

- Open Spaces Act.

\footnotetext{
${ }^{134}$ See, in particular, GS McBain, Our Criminal Law should only be 200 years out of Date (2014) Review of European Studies, vol 6, no 2, pp 1-35. See also many articles published in the Australian LJ, Legal Studies, King's LJ, Coventry LJ, Journal of Politics and Law ('JPL'). International Law Research ('ILR') and Public Administration Research on modernising the criminal law.

${ }^{135}$ e.g. see: (a) GS McBain, Abolishing the Statute of Frauds 1677, s 4 [2010] Journal of Business Law ('JBL'), no 5, pp 420-43: (b) Repealing the Factors Act 1889 [2016] ILR, vol 5, no 1, pp 254-304.

${ }^{136}$ e.g. various articles by GS McBain: (a) Time to Abolish the Common Carrier [2005] JBL, September, pp 545-96; (b) Abolishing the Strict Liability of Hotelkeepers [2006] JBL, October, 705-55; (c) Codifying Common Law Liens (2006), no 20(4), Commercial LQ ('CLQ'), pp 347; (d) Codifying the Law on Consensual Security: Pledges and Liens (2006) no 21(1), CLQ, pp 24-47; (e) Modernising and Codifying the Law of Bailment [2008] JBL, no 1, pp 1-63, (f) Abolishing Deeds, Specialities and Seals - Pts 1 \& 2 (2006) no 20(1), CLQ pp 15-54 \& 20(2), CLQ, pp 3-28; (g) Modernising the Law of Notarisation and Pubic Notaries [2016] JBL, no 2, pp 91-114; (h) The Strange Death of the Law Merchant [2016] ILR, vol 5, no 1, pp 32-151; (i) Modernising the Law on Gift [2016] ILR, vol 5, no 1, pp 168-236; (j) Abolishing the Doctrine of Consideration [2018] ILR, vol 7, pp 1-197; (k) Legal Documents - Modernsing the Formalities [2019] ILR, vol 8, no 1, pp 1-29; (1) Repealing the Bills of Sale Acts [2011] JBL, no 5, p 475-512.
} 
The latter would cover parks, allotments, common land etc. This would not be difficult if obsolete legislation ${ }^{137}$ and common law material was removed. ${ }^{138}$ These matters are dealt with in detail in various articles; ${ }^{139}$

- Constitutional Law. As previously noted, all constitutional law could be placed in a:

$$
\begin{aligned}
& \text { - } \text { Crown Act; }{ }^{140} \\
& \text { - } \text { Parliament Act; }{ }^{141} \\
& \text { - Courts Act; and a } \\
& \text { - Government Act }{ }^{142}
\end{aligned}
$$

Consolidating such material would give back intelligibility and coherence to the law on our constitution. Such is not just important for democracy in the UK - it would help the same in those Commonwealth countries which follow the Westminster model.

None of the above is difficult. What is simply needed is for ministries to consolidate legislation (e.g. the Home Office and the MOJ to consolidate criminal legislation into 4 Acts) and retired judges/law commissioners to issue (short) reports on potentially obsolete legislation and common law material relating to general legislation. Thus, a Courts Act should provide something to the effect that:

(1) All ministries must consolidate all general legislation for which they are responsible into one (or more) consolidation Acts.

(2) Subsequent to (1), further review and consolidation must be undertaken every 7 years.

(c) $\underline{\text { SI'S }}$

Up until the 1970's, ministries were (generally) good at consolidating SI's which is done by in-house ministry lawyers. However, thereafter, little emphasis was given to this. Also, the volume of SI's increased. It is now at ridiculous levels. At least, 30,000 - 35,000 SI's are extant.

- $\quad$ such is quite impossible for lawyers to read (and understand) in respect of one area of law - let alone all;

- further, it spawns a large bureaucracy -as well as a huge cost to business - in seeking to comply with them;

- further, pre-1980 SI's are not on the government website (legislation.gov.uk). Thus, they are difficult to locate and there is no wordsearch.

\footnotetext{
${ }^{137}$ There are a large number of Inclosure Acts still extant - both general (e.g. Inclosure Acts of 1773, 1833, 1845, 1846, 1848, 1849, 1852, 1854, 1857, 1859 and 1914) as well as prívate and local Acts (c. 4,000 of them). This inclosure legislation was last availed of in 1914 (at the latest) since the Commons Act 1876 (extant) was designed to supercede these Acts - the policy no longer being one of inclosure, but of regulation. Further, there are no open field systems (for inclosure) left in England and Wales (save for one deliberately preserved at Laxton in Nottinghamshire). Thus, all these Acts can be repealed. There are also Victorian Acts which provide for small pieces of common land to be set aside for buildings schools, churches (rectories) and institutes (e.g. the Literary and Scientific Institutes Act 1854, the School Sites Acts 1841-52 and the Gifts for Churches Act 1811). These are also redundant and can be abolished. Further, settled land can no longer be created post-1996 (nearly 25 years ago). Thus, the few settled estates still existing should be governed by the Trusts of Land and Appointment of Trustees Act 1996 - with the Settled Land Act 1925 and the Statute de Donis Conditionalibus 1285 (dealing with entailed interests) being repealed, as well as related legislation.

${ }^{138}$ For many years, standard land law texts have pointed out that the Norman tenurial system (that is, one in which all land is held directly (or indirectly) from the Crown) should be abolished. Such will have no practical effect since: (a) all forms of tenurial service (such as knight's service $e t c$ ) have long ended (save for some ceremonial ones such as grand sarjeanty at coronations); (b) there are no benefits from a person being a mesne (intermediate lord) or from escheat. Abolition will enable much old law to be dispensed with. Also, it will enable all land in England and Wales to be held directly by way of freehold or leasehold. Similarly, manorial law is redundant since no new manors could be created post-1290; also, a 'true' (real) manor must have an active court baron to exist. Since courts baron no longer sit (from 1977, at least) all (or most) manors, today, are merely reputed (alleged) manors - many of dubious provenance. Further, manorial benefits are of scant worth in almost all instances. Thus, manors - as a legal concept - should be abolished and any registrable manorial rights de-linked from being attached to a manor as such. Further, the law on oaths was formulated by the Norman rulers on the basis of military and landholding obligations which no longer exist. Also, oaths are not legally - only morally - binding (with only one or two forms of oath incurring a punishment as the result of a person, when obliged, failing to provide the same). Since oaths are predicated in a person believing in God they have no value if the oathgiver does not so believe. Thus, any requirement to give an oath should be abolished (and any affirmation given in lieu, should be restricted to only a few instances).

${ }^{139}$ viz. Articles by GS McBain: (a) Modernising English Land Law [2019] ILR, vol 8, no 1, pp 30-84; (b) Modernising English Land Law - Pt 2; [2019] ILR, vol 8, no 1, pp 85-131; (c) Modernising the Law on Oaths and Affirmations [2020] ILR, vol 9, no 1, pp 1-53; (d) The Case for Abolishing Manorial Franchises amd Customs (2013) Coventry LJ, vol 18, no 1, pp 43-68.

${ }^{140}$ See $\mathrm{n} 1$.

${ }^{141}$ See $\mathrm{n} 2$.

${ }^{142}$ This would deal with the present structure of government as well as remaining Crown prerogatives (whether to be abolished or placed in legislation).
} 
The solution is simple. Not least, since (very) many SI's are either spent (simply indicating the commencement date of Acts etc) or they have only a few sections. The key is to have SI's with a large number of sections that can be put on the Government legislation website, with word search. Thus, a Courts Act should provide that:

(1) All ministries must consolidate all SI's for which they are responsible:

(a) into one (or more) SI's (of, up to, 600 articles),

(b) commencing with the earliest.

(2) Subsequent to (1), further review and consolidation must be undertaken every 5 years.

Possibly, a time frame in the case of (1) should also be inserted ( 2 years would be quite adequate). If this were done, then, the number of SI's (likely) could be reduced to 1500 or less. Further, SI's would, then, be up to date as opposed to many being more than 100 years old. Such would be undertaken by in-house lawyers and would not be difficult.

\section{JUDICIAL ASSISTANCE}

It would be useful for SC and CA judges to be able to assist HC judges to clear any backlog in cases. Also, to issue reports (under the aegis of the Law Commission) in order to help clear the large backlog of obsolete legislation and common law material. CA (and SC) judges would be especially useful in this task given their practical experience and knowledge base.

Further, DFID has huge sums at its disposal (up to $£ 15 \mathrm{bn}$ pa) for development aid. Surely, a tiny fraction of this should be used to enable SC, CA or HC judges (whether sitting or retired) to sit as judges in foreign countries (especially some of the 53 Commonwealth countries) in order to help such courts, with their expertise and impartiality. Also, for retired members of the Law Commission to help foreign law commissions.

In conclusion, a Courts Act should make provision on the above.

\section{CONCLUSION}

Our courts system is still very much Victorian in structure and outlook. The cost in terms of money - and time wasted - to taxpayers and commerce is immense (probably, more than $£ 1 \mathrm{bn}$ a year). Yet, at the beginning of the $21^{\text {st }}$ century still nothing has been done. The steps would be simple, however, if there was willpower (and one or two vested interests were to step aside). Thus, this article asserts the following (which, surely, is reasonable to most reasonable people?):

- Legislation on the courts should be consolidated into one Courts Act;

- Obsolete courts should be abolished (including Parliament acting as a court);

- The Judicial Committee of the Privy Council should merge with the Supreme Court;

- The Court Martial Court of Appeal should merge with the Court of Appeal;

- The Crown Court should merge with the High Court;

- The County and Magistrates' courts should merge with the High Court;

- Ministries should take responsibility for their general legislation and SI's. Also, to consolidate the same, removing obsolete material every 7 years (in the case of legislation) and every 5 years (in the case of SI's).

- Issues relating, inter alia, to court buildings, court websites, wigs, robes, a barrister's fee, a CJ's report, should be considered. Also, judicial titles should be simplified.

One would suggest that most lawyers (barristers and solicitors) would agree with all the above (save, possibly, in respect of county and magistrates' courts) since streamlining the court system will improve (and speed up) throughput, which is how most lawyers garner their income these days. A few judges (and a number of civil servants) would (likely) be unhappy at the removal of a 'cushy' billet. However, should the court system be at the mercy of a selfish few? Or should it be reformed to achieve its primary purpose - the prompt bringing of impartial justice? Finally, for anyone who asserts that any of the reforms outlined above is difficult, costly, or time consuming (needing large committees and endless consultation papers so beloved of some civil servants) one would beg to differ. It is the opposite. 
Date

$\underline{\text { Act }}$

\section{APPENDIX A}

\section{Legislation applying to Courts}

Justice of the Peace Act

Juries Act

Judicial Committee Act

Judgments Act

Limitation of Actions and Costs

Judicial Committee Act

Judicial Committee Act

Criminal Justice Administration Act

Privy Council Registrar Act

Review of Justices Decisions

Summary Jurisdiction (Process) Act

Sheriffs Act

Judicial Committee Amendment Act

Appellate Jurisdiction Act

Criminal Justice Administration Act

Judicial Committee Act

Administration of Justice

Administration of Justice

Criminal Justice Act

Administration of Justice (Miscellaneous Provisions)

Foreign Judgments (Reciprocal Enforcement) Act

Law Reform (Miscellaneous Provisions)

Court Martial (Appeals) Act

Magistrates' Courts (Appeals from Binding over Orders) Act

Administration of Justice Act

Administration of Justice Act

Administration of Justice Act

City of London Courts Act

Administration of Justice Act

Criminal Justice Act

Justice of the Peace Act

Court Martial (Appeals) Act

Criminal Appeals Act

Administration of Justice Act

Administration of Justice Act

Courts Act

Criminal Justice Act

Administration of Justice Act

Juries Act

Litigants in Person

Administration of Justice Act

Charging Orders Act

Magistrates Courts Act

Judicial Pensions Act

Senior Courts Act

Administration of Justice

County Courts Act

Contempt of Court

Administration of Justice

Magistrates Courts (Procedure) Act

Courts and Legal Services Act

Criminal Appeal Court

Access to Justice Act

Courts Act 2003

Constitutional Reform Act

Legal Services Act

Legal Aid, Sentencing and Punishment of Offenders Act

\section{No of Sections ${ }^{143}$}

20

4

2

13

12

3

3

7

Total no of Acts:

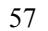

${ }^{143}$ Excludes sections dealing with: short title, interpretation, consequential, transitional, amending or repealing other legislation. 


\section{APPENDIX B: OBSOLETE COURTS}

\section{(a) Courts referred to in Administration of Justice Act 1977, s 23}

This Act, s 23 specifies a number of courts which - from 1977 - ceased to have any jurisdiction to hear, and determine, legal proceedings but which might continue to 'sit and transact such other business, if any, as was customary for it' prior to the coming into force of the Act. The courts referred to comprise:

- $\quad$ courts baron (ie. manorial courts exercising civil jurisdiction);

- $\quad$ courts leet (ie. manorial courts exercising criminal jurisdiction);

- $\quad$ customary courts of the manor (ie. manorial courts exercising civil jurisdiction re copyholders); ${ }^{144}$

- $\quad$ courts of pie poudre (piepowder)(ie. temporary courts at fairs and markets administering the law merchant): ${ }^{145}$

- $\quad$ courts of the staple (courts in designated towns which dealt with claims of merchants - especially foreign ones): ${ }^{146}$

- $\quad$ courts of clerks of the market (courts in fairs and markets which punished for false weights and measures): ${ }^{147}$

- $\quad$ hundred courts (courts of hundreds, when shires were divided into the same, dealing with civil and criminal matters);

- law days (it signified a court leet or a sheriff's tourn (the latter abolished in 1887);

- $\quad$ views of frankpledge (where subjects, in groups of 10 households, agreed to be mutually responsible for each other);

- common law (or sheriffs') county courts as known before the passing of the County Courts Act 1846.

Section 23 also referred to various specific courts (sch 4, pts $2 \& 3$ ), all of which fell within the above categories. It is asserted that all such courts should now be abolished (with any criminal jurisdiction they possess being transferred to the relevant magistrates' court and any civil jurisdiction to the county court) since, in practice, since 1977 they have not sat for any legal purposes and such 'customary purposes' they now perform are simply ceremonial (including the estray court of Denbigh and court leet of the manor of Laxton). Further, such courts do not meet the requirements of the European Human Rights Convention, art 6 (see HRA 1998) which requires an 'independent and impartial tribunal' established by law.

\section{(b) Court of the Chamberlain of the City of London (City of London apprentices' court)}

This court determined disputes between masters and apprentices in the City of London (now, the Square Mile), with the chamberlain sitting as a judge and the comptroller (controller) as his deputy. It administered criminal punishment of apprentices and masters, concurrent with that of a magistrates' court. This court does not appear to have sat for, at least, 100 years and in 1894, a Royal Commission recommended its abolition. Further, this court would not meet the requirements of the European Human Rights Convention, art 6 (see above, the chamberlain of the City of London is not necessarily a lawyer). This court should be abolished (it would seem unnecessary for any jurisdiction to be transferred to the magistrates' court since it had concurrent jurisdiction with it anyway).

\section{(c) Court of the Duchy Chamber of Lancaster (Duchy of Lancaster chancery court)}

This was held before the Chancellor of the duchy (or his deputy). It had jurisdiction concerning equities relating to land held of the Queen in the duchy ${ }^{148}$ Its jurisdiction was concurrent with that of the courts of Exchequer and Chancery (now part of the High Court). This court has not sat since 1835. Further, this court would not meet the requirements of the European Human Rights Convention, art 6 (see above). This court should be abolished. It would seem unnecessary for any jurisdiction to be transferred to the High Court since it had concurrent jurisdiction with it anyway.

\section{(d) High Court of Chivalry (Armorial court)}

This court last sat in 1954 (in the Royal Courts of Justice, with the LCJ acting as surrogate for the earl marshall (the Duke of Norfolk)) and, prior to that, in 1737. It seems now only to have jurisdiction re armorial matters. This court would not meet the requirements of the European Human Rights Convention, art 6 (see above) if the earl marshall were to sit as a judge. This court should be abolished (including any criminal jurisdiction) with any civil jurisdiction being transferred to the High Court.

\section{(e) Cinque Ports Court of Admiralty (Cinque Ports admiralty court)}

This court last sat in 1914 (with the Cinque Ports Act 1821 providing for its jurisdiction to extend from Shore Beacon in Essex to Redcliffe in Sussex). Its marshall had his office merged with that of the admiralty judge of the Cinque Ports, an office usually held by a High Court admiralty judge (his full title is 'Judge Official and Commissary of the Court of Admiralty of the Cinque Ports'). This court should be abolished and the Cinque Ports Acts $1821^{149}$ and $1855^{150}$ repealed, with any salvage jurisdiction transferred to the High Court.

\section{(f) Courts of the Vice-Admirals of the Coast (Local admiralty courts)}

The sea coast of England and Wales was divided into 19 districts - for each of which a Vice-Admiral of the coast could be appointed by letters patent, representing the Lord High Admiral. These courts had jurisdiction over all causes of merchants and mariners, happening on the sea or in foreign parts within the king's dominions. Also, of crimes within the above limits, and of all maritime causes where the common law could

\footnotetext{
${ }^{144}$ Copyhold was abolished in 1925.

${ }^{145}$ The last piepowder court sat in 1898

${ }^{146}$ The towns where 'staple courts' were to be held, were listed in legislation, all of which has now been repealed.

${ }^{147}$ The last time the office (court) of the clerk of the market (as a king's officer) was exercised seems to have been in 1738

${ }^{148}$ For the historical position see G Crabb, A History of English Law (London, 1829), p 508.

${ }^{149}$ The Act provides for the Warden of the Cinque Ports to appoint commissioners for salvage, who have power to determine salvage matters within the jurisdiction of the Cinque Ports (ss 1-6, 12). Since the Warden is now only a ceremonial post and would not so appoint (in the past the Warden was treated as a magistrate) these sections are no longer necessary. It is unclear whether they have ever been availed of

${ }^{150}$ The 1855 Act removed the privileged jurisdiction of the Cinque Ports $r e$ writs and judgments (s 2, spent), saving the Warden's jurisdiction in the 1821 Act (s 10). This Act is also unnecessary
} 
give no remedy. These courts were said, in 1884, to have fallen into desuetude within the last 100 years. ${ }^{151}$ These courts should be abolished, any jurisdiction being transferred to the High Court (Admiralty).

\section{(g) Colonial Courts of Admiralty and Vice Admiralty (Colonial admiralty courts)}

The Colonial Courts of Admiralty Act 1890 provided for the establishment of the above in colonies - now BOT. ${ }^{152}$ It is unclear whether any such BOT courts of admiralty exist. These courts should be abolished, with any jurisdiction (including prize jurisdiction) passing to the High Court in the case where any BOT does not otherwise have jurisdiction pursuant to an SI under the 1890 Act (there appear to be no SI's). Consideration should also be given to repealing the 1890 Act and simply providing that any civil court in a BOT shall have admiralty jurisdiction and, failing the presence of such a civil court, the High Court (admiralty court) shall have jurisdiction.

\section{(h) Court of the Lord High Steward (House of Lords, Impeachment court)}

This court (instituted in the reign of Henry IV (1399-1413)) handled impeachments when Parliament was not sitting (otherwise, the Lord Chancellor sits). The last impeachment was in 1806, the last successful one in 1746. This court is defunct, since it cannot now sit: the judges who sat in the House of Lords being its judges when Parliament was not otherwise sitting. ${ }^{153}$ Even if abolished, impeachments could still be heard with Lord Chancellor sitting. ${ }^{154}$ This court last sat in 1686 (trial of Lord Delamere);

\section{(i) Court of Claims (Coronation claims court)}

This court handles claims to attend the coronation of a monarch. The nature, and proceedings, of this court has always been very uncertain (e.g.whether there is a right to appeal). The court that sat for Elizabeth II in 1952 comprised the Lord Chancellor, Earl Marshall (Duke of Norfolk, not a judge), Lord Clarendon (not a judge), Lord Jowitt, Lord Porter, Lord Goddard LCJ, Lord MacDermott (LCJ, Northern Ireland), Lord Cooper (Lord President, Court of Session) and Sir Francis Evershed (Master of the Rolls). Thus, this court may not satisfy the ECHR, art 6 (see above) in that it is purporting to determine an issue legally. It would seem appropriate (not least, to permit an appeal) for the jurisdiction of this court to pass to the High Court.

\section{(j) Courts of Attachment of the New Forest and Forest of Dean (Forest courts)}

These courts, also called 40 day courts, inquired into infractions of the forest law in respect of vert and venison in the New Forest and the Forest of Dean, but could not convict. However, forest law was abolished by the Wild Creatures and Forest Laws Act 1971. These courts should be abolished and any jurisdiction transferred to the relevant magistrates' court. Halsbury, Laws (1909, vol 9) also mentions the Eyre (or Justice Seat court) which has not sat since 1662 (p 114) and the Regard (or Survey) of Dogs court (p 122 'obsolete for centuries'). They also should be abolished (although they were likely abolished with the abolition of the forest law in any case).

\section{(k) Courts of Verderers of the New Forest and Forest of Dean (Forest courts)}

These courts (also called courts of Swainmote or Swanimote) dealt with infractions of forest law. They are treated as a magistrates' court (New Forest Act 1877, s 33 and Forestry Act 1967, s 47). However, that of the Forest of Dean has not sat since 1902 and, given that the New Forest court also passes New Forest byelaws, it would seem to conflict with the ECHR, art 6 . Jurisdiction of these courts should now pass to the relevant magistrates' court.

\section{(I) Barmote Courts of the High Peak \& Wirksworth (Lead mining courts in Derbyshire)}

The Barmote Courts of the High Peak at Monyash (it covers the high peak) and of Wirksworth (it covers the low peak) exercise civil jurisdiction relating to lead mining rights pursuant to the High Peak Mining Customs and Mineral Courts Act 1851 and the Derbyshire Mining Customs and Mineral Courts Act 1852. It is unclear when these courts last sat in other than a ceremonial capacity (the last lead mine in Derbyshire closed in 1939). Today, they meet (annually) in Wirksworth but only in a ceremonial capacity (in a pub). This does not meet the requirements of the ECHR, art 6 (see above). These courts should be abolished and any jurisdiction transferred to the relevant county court.

\section{(m) Royal Court of Shepway \& Court of Brotherhood and Guestling (Cinque Ports courts)}

The Royal Court of Shepway (presided over by the Warden of the Cinque Ports), existed by 1150. It exercised civil and criminal jurisdiction within the Cinque Ports (Dover, Sandwich, Romney, Hastings, Hythe) and, later, the two Ancient Towns (Winchlesea and Rye), effectively comprising a shire court. However, its work passed to the Lord Warden's court at Dover and the Royal Court of Shepway became defunct from the $16^{\text {th }}$ century onwards, when its only business then was ceremonial - to meet to install a Warden. The Court of Brotherhood and Guestling (by the $17^{\text {th }}$ century the courts of Brudhull and Guestling had combined) is unlikely to have been a legal court as such. Rather, an assembly to celebrate special events. Any legal jurisdiction of these courts should be abolished - without prejudice to their assembling for ceremonial purposes, viz. the election of a Warden.

\section{(n) Vice Warden's Stannary Court (Devon and Cornwall mining courts)}

At least since 1201, steward's courts existed in the 8 mining districts of Devon and Cornwall (each district being known as a stannary). There was also a second stannary institution - the equitable jurisdiction of the Vice-Warden of the Stannaries. The Stannaries Act 1836 amalgamated the stannary courts into the Vice-Warden's court. The latter, becoming defunct by 1870 (it had no business), the Stannaries Court (Abolition) Act 1896 abolished it - transferring jurisdiction to the county courts of

\footnotetext{
${ }^{151}$ By 4 \& 5 Will IV c 36 (1835-6) \& 7 Vict 2 (1844), all offences on the high seas and other places within the admiralty of England could be tried in the Central Criminal Court or before ordinary judges of the land.

${ }^{152}$ The Act abolished any existing Vice-Admiralty courts (s 17). Also, it provides that, any court of law with civil jurisdiction in a colony, shall include therein an admiralty jurisdiction (s 2(1)).

${ }^{153}$ B O’Donnell, Calvacade of Justice (1951), p 151.

${ }^{154}$ That said, the House of Lords (it is asserted) can no longer hear impeachments because it no longer has judges to advise them (see also European Human Rights Convention, art 6). Further, the Lord Chancellor is (often) no longer a lawyer.
} 
Cornwall (which still hold this jurisdiction). ${ }^{155}$ The 1836 (ss 4, 6-7), 1855 (s 1) and 1896 Acts (ss 1, 3-4) ) being spent, should be repealed. Consideration should, also, be given to the HC having exclusive jurisdiction over all cases relating to mining since this is a specialist area.

In conclusion, all obsolete common law courts should be abolished with their jurisdiction transferred to the county court (civil jurisdiction) and to the magistrates' court (criminal). Such would only, then, leave statutory courts (viz, SC, JCPC, CMCA, CA, HC, CC, county courts and magistrates courts).

\section{APPENDIX C - A COURTS ACT}

An Act to consolidate and reform various matters relating to courts.

\section{$\underline{\text { Contents }}$}

\section{Supreme Court, Court of Appeal, High Court}

1. Supreme Court (SC), Court of Appeal (CA), High Court (HC)

2. Composition

3. Title

4. Style of Judges

5. Divisions

6. Maximum number of Judges

7. Increase in maximum number of Judges

8. Tenure of Judges

9. Precedence of Judges

10. Powers

11. Due Constitution

12. Rules

13. Location

14. Sittings and Vacations

15. Judicial Assistance

16. Seal

17. Statutory Instruments

\section{Jurisdiction of the SC}

18. Jurisdiction

19. Civil appeals

20. Criminal appeals - CA to SC

21. Criminal appeals - $\mathrm{HC}$ to $\mathrm{SC}$

\section{Jurisdiction of the CA}

22. Jurisdiction

23. Appeals from the $\mathrm{HC}$

24. Applications for a New Trial

25. Restrictions on Appeals

26. Second Appeals

27. Assignment of Appeals

28. Criminal appeals

\section{Jurisdiction of the HC}

29. Jurisdiction

\section{Certain Appeals}

30. Appeals in Cases of Contempt of Court or Habeas Corpus

\section{Other Courts}

31. Judicial Committee of the Privy Council

32. Court Martial Court of Appeal

33. Crown Court

34. County Court

35. Magistrates' Courts

\footnotetext{
${ }^{155}$ See also $R v$ East Powder Justices ex $p$ Lampshire [1979] 2 AE 329 (the power contained in the Magistrates Act 1980, s 2 overrides any vestiges of stannary law in relation to matters which survived repeal by the 1896 Act). Also, per Robert Goff at $\mathrm{p} 335$, any criminal jurisdiction of the stannary courts were abolished by the $1896 \mathrm{Act}$; it only transferred civil jurisdiction to the county court.
} 


\section{Obsolete Courts}

36. Parliament as a court

37. Other courts

\section{$\underline{\text { General }}$}

38. Concurrent Administration of Law and Equity

39. Central Office

40. Accountant General

41. Official Solicitor

42 Judicial Appointments Commission

43. Judicial Appointments and Conduct Ombudsman

44. Selection of Judges for Election Petitions

45. [District and Probate Registries]

46. Lord Chancellor

47. Chief Justice

\section{Other Legal Matters}
48. Court Buildings
49. Court Websites
50. Wigs and Robes
51. Barrister's Fee
52. Chief Justice's Report
53. Law Commission
54. Publication of Information in Private Proceedings

\section{$\underline{\text { Legislation }}$}

55. Responsibility

56. Consolidation

57. Form

58. Local and Private

\section{General}

59. Repeals

60. Supplementary

61. Interpretation and Application

$\begin{array}{ll}\text { Schedule 1 } & \text { Divisions of the CA } \\ \text { Schedule 2 } & \text { Divisions and Courts of the HC } \\ \text { Schedule 3 } & \text { Powers of the HC } \\ \text { Schedule 4 } & \text { Due Constitution } \\ \text { Schedule 5 } & \text { Rules of Court } \\ \text { Schedule 6 } & \text { Judicial Assistance } \\ \text { Schedule 7 } & \text { Process for Criminal Appeals from the CA to the CS } \\ \text { Schedule 8 } & \text { Process for Criminal Appeals from the HC to the CS } \\ \text { Schedule 9 } & \text { Process for Appeals to the CA } \\ \text { Schedule 10 } & \text { Jurisdiction of the HC } \\ \text { Schedule 11 } & \text { Appeals re Contempt of Court or Habeas Corpus } \\ \text { Schedule 12 } & \text { Transfer of Jurisdiction of the JCPC } \\ \text { Schedule 13 } & \text { Obsolete Courts } \\ \text { Schedule 14 } & \text { Judicial Appointments Commission } \\ \text { Schedule 15 } & \text { Judicial Appointments and Conduct Ombudsman } \\ \text { Schedule 16 } & \text { [District Registry] } \\ \text { Schedule 17 } & \text { [Probate Register] } \\ \text { Schedule 18 } & \text { Lord Chancellor } \\ \text { Schedule 19 } & \text { Repeals }\end{array}$

\section{Supreme Court, Court of Appeal and High Court}

(1) There shall continue to be a:
(a) Supreme Court ('SC');
(b) Court of Appeal ('CA')
(c) High Court ('HC')

\section{Composition}

(1) The SC shall comprise persons appointed: 
(a) its judges by HM by letters patent,

(b) including the appointment of one judge to be President and one to be Deputy President. ${ }^{156}$

(2) The CA shall comprise persons appointed:

(a) its judges by HM by letters patent; and

(b) the CJ and the MR, ex officio. ${ }^{157}$

(3) The HC shall comprise persons appointed:

(a) its judges by HM by letters patent; ${ }^{158}$ and

(b) the: (i) CJ; (ii) President of the Queen's Bench Division; (iii) President of the Family Division; (iv) Chancellor of the HC; (v) Senior Presiding Judge; (vi) Vice-President of the Queen's Bench Division. ${ }^{159}$

3. Title

(1) The title of the:

(a) SC is the 'Supreme Court of the United Kingdom' (or 'Supreme Court of the UK' or 'Supreme Court'); ${ }^{160}$

(b) $\mathrm{CA}$ is the 'Court of Appeal'; 161

(c) $\mathrm{HC}$ is the 'High Court of Justice"162 or 'High Court'.

\section{Style of Judges}

(1) Judges of the SC (except 2(1)(b)), the CA (except 2(2)(b)) and the HC (except 2(3)(b)) shall be styled as follows:

(a) SC - 'Justice of the Supreme Court'163 (or 'Supreme Court judge');

(b) CA - 'Justice of the Court of Appeal'164 (or 'Court of Appeal judge');

(c) HC - 'Justice of the High Court' (or 'High Court Judge').

\section{Divisions}

(1) The SC shall have no divisions. ${ }^{165}$

(2) The CA shall have criminal and civil divisions. They shall operate in accordance with Sch $\mathbf{1}{ }^{166}$

(3) The HC shall have criminal and civil divisions. They shall operate in accordance with Sch $2 .{ }^{167}$

(4) The HC shall contain the courts referred to in Sch 2 and: ${ }^{168}$

(a) such may be increased (or decreased or merged) by a SI if determined by the LC and the CJ. ${ }^{169}$

(b) the divisions 'Queen's Bench Division' and 'Chancery Division' are abolished. ${ }^{170}$

\section{Maximum Number of Judges}

(1) The maximum number of judges in the:

(a) SC shall be 12 (including the President and Deputy President); ${ }^{171}$

(b) CA shall be 39 (excluding any judge in 2(2)(b)) ${ }^{172}$

(c) HC shall be 108 (excluding any judge in $2(3)(\mathrm{b})$ )

\footnotetext{
156 This reflects the 2005 Act, ss 23(2) \& (5).

157 See 1981 Act, s 2(2). Reference is also made to the Presidents of the QBD and the Family Division and the Chancellor of the HC (see s 2(2), other references are spent). However, consideration should be given to excluding these, as no longer necessary (they cannot be required to sit in any case, unless they consent). Further, it may be more appropriate for the CJ and the MR to sit permanently in the CA (heading the criminal and civil divisions respectively).

${ }_{158} 1981$ Act, s 4(1)(puisne).

${ }^{159} \mathrm{Ibid}, \mathrm{s} 4(1)$. If the QB, Chancery and Family Divisions are abolished and (like the CA) the HC is simplified into 2 divisions (criminal and civil), then, it may be appropriate to only have a head of each (i.e. a President and Deputy President of the HC).

${ }^{160}$ This reflects the 2005 Act, s 23(1).

1611981 Act, s 2(1).

162 Ibid, s 4(2).

1632005 Act, s 23(6)

1641981 Act, s 2(3).

${ }^{165}$ Legislation relating to the SC makes no provision for any division, which seems appropriate.

166 See 1981 Act, s 3 .

${ }^{167}$ Ibid, s 5.

${ }^{168}$ See also 1981 Act, s 6 (patents, admiralty, commercial courts). Also, 20-4 (admiralty), 25 (probate), 26 (matrimonial), 27 (prize). The latter conceopt should be considered for abolition, see $\mathrm{n} 39$.

${ }^{169}$ Ibid, $\mathrm{s} 7$ (power to alter courts).

${ }^{170}$ Ibid, s 5 .

171 This reflects the 2005 Act, s 23(2).

${ }^{172}$ See 1981 Act, s 2(1). If the same is now limited to the CJ and the MR (see n 157), direct reference may be made to the same.
} 
(2) No appointment may cause the full-time equivalent number of judges at any time to be more than the number stipulated in (1). It shall be calculated by taking the number of full-time judges and adding:

(a) for each judge who is not a full-time judge,

(b) such fraction as is reasonable. ${ }^{173}$

\section{Increase in the Maximum Number of Judges}

(1) HM may, from time to time, by Order in Council increase (or further increase) the number of judges stipulated in $6(1) .{ }^{174}$

(2) It is for the LC to recommend to HM the making of an Order under (1). ${ }^{175}$

(3) No recommendation may be made to HM in Council to make an Order under (1) unless:

(a) a draft of the Order has been laid before and approved

(b) by resolution of each House of Parliament. ${ }^{176}$

\section{Tenure of Judges}

(1) This section applies to the office of any judge of the courts in section 1 .

(2) A person appointed to an office to which (1) applies shall vacate it:

(a) on the day on which he attains the age of 70 years,

(b) unless by virtue of this section he has ceased to hold it before then.

(3) A person appointed to an office to which (1) applies shall:

(a) hold it during good behaviour,

(b) subject to a power of removal by HM

(c) on an address presented to HM by both Houses of Parliament.

(4) It is for the LC to recommend to HM the exercise of the power of removal under (3).

(5) A person holding an office within section 2(3)(b) shall vacate that office on becoming a judge of the SC.

(6) A judge of the CA shall vacate that office on becoming an ex-officio judge of the CA.

(7) A judge of the $\mathrm{HC}$ shall vacate that office on becoming a judge of the CA.

(8) A person who holds an office to which this section applies may at any time resign it by giving the LC notice in writing to that effect.

(9) The LC, if satisfied by means of a medical certificate that a person holding an office to which this section applies is -

(a) disabled by permanent infirmity from the performance of the duties of his office; and

(b) for the time being incapacitated from resigning his office,

he may, subject to (9), by instrument under his hand declare that person's office to have been vacated; and

(c) the instrument shall have the like effect for all purposes as if that person had

(d) on the date of the instrument resigned his office.

(10) A declaration under (9) with respect to a person shall be of no effect unless it is made in the case of -

(a) any of the CJ, MR, [the President of the [QBD], the President of the Family Division and the Chancellor of the HC with the concurrence of two others of them], ${ }^{17}$

(b) a judge of the CA with the concurrence of the MR;

(c) a judge of the $\mathrm{HC}$ (except where (a) applies) with the concurrence of the senior judge of that division. ${ }^{178}$

\section{Precedence of Judges}

(1) When sitting in the CA -

(a) the CJ and the MR shall rank in that order; and

(b) SC judges and persons who have been LC shall rank next after the MR and, among themselves, according to the priority of the dates on which they respectively became SC judges or LC, as the case may be.

\footnotetext{
173 This reflects the 2005 Act, s 23 (8). For the CA, see 1981 Act, s 2(7). For the HC, see 1981 Act, s 4(7).

${ }_{174}$ Ibid, s 23(3). For the CA, see 1981 Act, s 2(4). For the HC, see 1981 Act, s 4(4).

${ }^{175}$ See 1981 Act, s 2 (4A)(CA) and s 4(4) (HC).

${ }^{176}$ For the CA, see s 2(5). For the HC, see 1981 Act, s 4(5).

${ }^{177}$ This will change if the $\mathrm{HC}$ abolishes the present divisions and the $\mathrm{CC}$ merges with it, so that there is a civil and a criminal division.

${ }^{178}$ See 1981 Act, s 11 (tenure of office of judges of senior courts).
} 
(2) Subject to (1)(b), the President of the [QBD] shall rank next after the MR.

(3) The President of the Family Division shall rank next after the President of the [QBD]. ${ }^{179}$

(4) The Chancellor of the HC shall rank next after the President of the Family Division.

(5) The vice-president(s)('VP') or VPs of the divisions of the CA shall rank next after the Chancellor of the HC; and if there are two VPs of those divisions, they shall rank, among themselves, according to the priority of the dates on which they respectively became VPs.

(6) Judges of the CA (other than the VP(s) of the divisions of the CA) shall rank after the ex-officio judges of the CA and, among themselves, according to the priority of the dates on which they respectively became such.

(7) Judges of the HC (except ex officio judges) shall rank next after the judges of the CA and, among themselves, according to the priority of the dates on which they respectively became such. ${ }^{180}$

\section{Powers}

(1) The judges of the [SC, the $\mathrm{CA}]$ and the $\mathrm{HC}$ shall, except where this Act expressly provides otherwise, have:

(a) in all respects equal power, authority and jurisdiction

(b) in the court of which they are a judge. ${ }^{181}$

(2) The courts in section 1 have the legal power (including for contempt of court) to: ${ }^{182}$

(a) fine;

(b) imprison;

(c) bind over for good behaviour (by requiring a recognisance or a surety(ies) or both);

(d) bind over to keep the peace (by requiring a recognisance or a surety (ies) or both).

and the power in 2 (c) or (d) shall apply whether a person has previously been convicted of a criminal offence or not. ${ }^{183}$

(3) The legal concept of a 'court of record' is abolished.

(4) A judge of the $\mathrm{SC}$, the $\mathrm{CA}$, the $\mathrm{HC}$ or the $[\mathrm{CC}]^{184}$ shall not be incapable of acting as such in any proceedings:

(a) by reason of being, as one of a class of ratepayers, taxpayers or persons of any other description, liable in common with others to pay, or contribute to, or benefit from, any rate or tax which may be increased, reduced or in any way affected by those proceedings, and

(b) "rate or tax" means any rate, tax, duty or liability, whether public, general or local, and includes - (i) any fund formed from the proceeds of any such rate, tax, duty or liability; and (ii) any fund applicable for purposes the same as, or similar to, those for which the proceeds of any such rate, tax, duty or liability are or might be applied. ${ }^{185}$

(5) The HC shall have the powers set out in Sch 3. ${ }^{186}$

\section{Due Constitution}

(1) The courts in section 1 are duly constituted despite any vacancy in any office referred in 2(1)(b), 2(2) (b) or 2(3) (b). ${ }^{187}$

(2) The SC is only duly constituted if the conditions in Sch $\mathbf{4}$ are satisfied. ${ }^{188}$

\section{Rules}

(1) Rules of court shall be made for the courts in section 1, including in respect of any court martial repeal, in the case of the CA

(2) Requirements as to (1) are set out in Sch $\mathbf{5 .}{ }^{190}$

\footnotetext{
${ }^{179}$ See $\mathrm{n} 177$.

${ }^{180}$ See 1981 Act, s 13

${ }^{181}$ Ibid, s 4(3) (HC). This provision should also apply to the SC and the CA.

182 The 2005, s 40(1) provides that the SC is a court of record. So too are the CA and HC (see 1981 Act, s 15 for the CA and s 19 (1) for the

HC). Therefore, they have the powers indicated in the Justice of the Peace Act 1968, s 1 (7), see n 90.

${ }^{183}$ In the past, this referred to a person being of 'good fame' or not (an Anglo-Saxon legal concept), see n 90.

${ }^{184}$ This non-inclusion depends on whether the CC merges with the HC or not.

${ }^{185}$ See SCA, s 14 (senior courts). This section should apply to the SC as well.

${ }^{186}$ See 1981 Act, ss 28A-44 and 50 (power to award damages). See also AJA 1969, ss 20 \& 21 and AJA 1985, ss 47-50

${ }^{187}$ See 2005 Act, s 23 (7). See 1981 Act, s 2(6) for the CA and s 4(6) for the HC.

${ }^{188}$ See 2005 Act, ss 42 \& 43.

${ }^{189}$ See 6.

${ }^{190}$ Ibid, ss 45 \& 46. See also Access to Justice Act 1999, s 54 (rules of court for permission to appeal to CA).
} 


\section{3. $\underline{\text { Location }}$}

(1) The SC shall sit in London. ${ }^{191}$

(2) The CA shall sit in London, save that:

(a) when hearing any court martial appeal,

(b) it may sit in any military base in the UK or in any BOT. ${ }^{192}$

(3) The HC shall sit in any locations in England and Wales as the LC and the CJ shall determine from time to time.

\section{Sittings and Vacation}

(1) The sitting and vacation of the courts in section 1 shall be set out in a SI.

\section{Judicial Assistance}

(1) Assistance for the transaction of judicial business shall be provided in accordance with Sch 6. ${ }^{193}$

(2) When requested by the CJ, a CA judge may:

(a) sit as a HC judge, to help clear any backlog;

(b) under the aegis of the Law Commission, issue a report on any matter of English law considered to be potentially obsolete, spent or in need of reform;

(c) sit as a judge in a court of the Commonwealth or a foreign country, if invited.

(3) When requested by the CJ, an HC judge (or any retired SC, CA or HC judge) may:

(a) under the aegis of the Law Commission, issue a report on any matter of English law considered to be potentially obsolete, spent or in need of reform;

16. Seal

(b) sit as a judge in a court of the Commonwealth or a foreign country, if invited. ${ }^{194}$

(1) Each court in section 1 shall have an official seal.

(2) Every document purporting to be sealed with the official seal or stamp of a court in (1) is to be received in evidence in all parts of the UK without further proof. ${ }^{195}$

\section{Statutory Instruments}

(1) One or more SIs shall specify, in respect of the courts in section 1 and any court in NI, the following:
(a) any fees and payments; ${ }^{196}$
(b) the: (i) appointment; (ii) terms of appointment; (iii) tenure; (iv) discipline; (v) retirement; (vi) resignation; (vii) removal or (viii) disqualification; of any judge ${ }^{197}$
(c) the staffing, resourcing and security of those courts; ${ }^{198}$
(d) the practice and procedure of those courts ${ }^{199}$
(e) judicial salaries and pensions; ; $^{200}$
(f) any supplementary matters, including photography. ${ }^{201}$

\section{Jurisdiction of the SC}

\section{Jurisdiction}

(1) The SC has power to determine any question necessary to be determined for the purposes of doing justice in an appeal to it under any enactment. This lies only with:

(a) the permission of the $\mathrm{CA}$ or the $\mathrm{SC}$;

\footnotetext{
${ }^{191}$ Possibly, legislative provision should be made in legislation for the SC to sit elsewhere.

192 See 6

${ }^{193}$ See 1981 Act, s 9 (assistance for transaction of judicial business).

194 See 19.

${ }^{195}$ See 2005 Act, s 55. Also, 1981 Act, s 132 'Every document purporting to be sealed or stamped with the seal or stamp of the Senior Courts or of any office of the senior courts shall be received in evidence in all parts of the [UK] without further proof.'

1962005 Act, ss $52 \& 53$

${ }^{197}$ Ibid, ss 63-137. See also 1981 Act, s 10 (appointment of judges of senior courts).

${ }^{198}$ Ibid, ss 48-51.

${ }^{199}$ See 2005 , ss 44-7.

${ }^{200}$ Ibid, s 12 (senior courts salaries)

${ }^{201}$ Such as the need for an annual report, see 2005 Act, s 54. See also AJA 1969, s 21.
} 
(b) but this is subject to provision under any other enactment restricting such an appeal. ${ }^{202}$

(2) In the SC in exercising its jurisdiction, nothing is to affect the distinctions between the separate legal systems of the parts of the UK. ${ }^{203}$

(3) A decision of the SC on appeal from a court of any part of the UK, other than a decision on a devolution matter, ${ }^{204}$ is to be regarded as the decision of a court of that part of the UK. ${ }^{205}$

(4) A decision of the SC on a devolution matter is:

(a) not binding on a court of any part of the UK when making such a decision;

(b) otherwise, is binding in all legal proceedings. ${ }^{206}$

\section{Civil Appeals}

(1) An appeal lies to the SC from any order or judgment of the CA in civil proceedings. ${ }^{207}$

\section{Criminal Appeals - CA to SC}

(1) An appeal lies to the CS, at the instance of the defendant or the prosecutor, from any decision of the CA in a criminal cause or matter under:

(a) [Part I of this Act]; (spent) or

(b) Criminal Justice Act 2003, part 9; or

(c) Criminal Justice Act 1987, s 9; or

(d) Criminal Procedure and Investigations Act 1996, s 35; or

(e) Criminal Justice Act 2003, s 47.

(2) An appeal lies to the CS, at the instance of the acquitted person or the prosecutor, from any decision of the CA on an application under the Criminal Justice Act 2003, ss 76(1) or (2)

(3) The appeal lies under (1) and (2) only with the leave of the CA or the SC and shall not be granted unless it:

(a) is certified by the CA that a point of law of general public importance is involved in the decision; and

(b) it appears to the CA or CS (as the case may be) that the point is one which ought to be considered by the CS.

(4) Except as provided herein and under [s 30] ${ }^{208}$ no appeal shall lie from any decision of the criminal division of the CA.

(5) In relation to an appeal under (2), references to a defendant are references to the acquitted person.

(6) Sch 7 shall apply in respect of the process of criminal appeal. ${ }^{209}$

\section{Criminal Appeals - HC to SC}

(1) An appeal shall lie to the SC, at the instance of the defendant or the prosecutor from any decision of the HC in a criminal cause or matter.

(2) The appeal lies under (1) only with the leave of the HC or the SC and such shall not be granted unless it:

(a) is certified by the $\mathrm{HC}$ that a point of law of general public importance is involved in the decision; and

(b) it appears to the $\mathrm{HC}$ or the $\mathrm{SC}$ (as the case may be) that the point is one which ought to be considered by the SC.

(3) For the purpose of disposing of an appeal under (1) the SC may:

(a) exercise any powers of the $\mathrm{HC}$; or

(b) may remit the case to the HC. ${ }^{210}$

(7) Sch 8 shall apply in respect of the process relating to criminal appeal. ${ }^{211}$

\footnotetext{
${ }^{202}$ Ibid, combining s $40(5) \&(6)$.

${ }^{203}$ Ibid, s 41. 'Parts of the UK' are defined in the 2005 Act, s 60.

${ }^{204}$ It may be better to put 'other than a decision on a devolution matter in (4)',

205 Ibid, s 41(2).

206 Ibid, s 41(3).

${ }^{207}$ Ibid, s 40(2).

${ }^{208}$ The reference is to the Administration of Justice Act 1960, s13 (appeal in cases of contempt of court).

${ }^{209}$ See Criminal Appeal Act 1968, ss 34, 36-8, 43-5.

${ }^{210}$ See AJA 1960, s 1 (tidied up)

${ }^{211}$ Ibid, ss 2,4-6, 9. Also, AJA 1969 (appeal from the HC to the SC), ss 12-3, 15-6.
} 


\section{$\underline{\text { Jurisdiction of the CA }}$}

\section{Jurisdiction}

(1) There shall be exercisable by the CA -

(a) all such jurisdiction (whether civil or criminal) as is conferred on it by this or any other Act; and

(b) all such other jurisdiction (whether civil or criminal) as was exercisable by it immediately before the Commencement of this Act. ${ }^{212}$

(2) For all purposes of or incidental to -

(a) the hearing and determination of any appeal to the civil division of the CA; and

(b) the amendment, execution and enforcement of any judgment or order made on such an appeal,

the $[\mathrm{CA}]$ shall have all the authority and jurisdiction of the court or tribunal from which the appeal was brought.

(3) It is hereby declared that any provision in this or any other Act which authorises or requires the taking of any steps for the execution or enforcement of a judgment or order of the $[\mathrm{HC}]$ :

(a) applies in relation to a judgment or order of the civil division of the [CA]

(b) as it applies in relation to a judgment or order of the $[\mathrm{HC}] .{ }^{213}$

(4) Sch 9 shall apply to any process relating to an appeal. ${ }^{214}$

\section{Appeals from the $\mathrm{HC}$}

(1) The [CA] shall have jurisdiction to hear and determine appeals from any judgment or order of the HC save where any of the following apply:

(a) s 13(2)(a) of the Administration of Justice Act 1969;

(b) an appeal is made from the HC to the CS pursuant to $\mathrm{s}[21] ; ;^{215}$

(c) as provided by any order made by the [LC] under [s] 56(1) of the Access to Justice Act 1999. ${ }^{216}$

(2) An appeal from a judgment or order of the [HC] when acting as a prize court shall not be to the [CA], but shall be to [HM] in Council in accordance with the Prize Acts 1864 to $1944 .^{217}$

\section{Applications for a New Trial}

(1) Where any cause or matter, or any issue in any cause or matter, has been tried in the HC, any application for a new trial thereof, or to set aside a verdict, finding or judgment therein, shall be heard and determined by the CA except where rules of court made in pursuance of (2) provide otherwise.

(2) As regards cases where the trial was by a judge alone and no error of the court at the trial is alleged, or any prescribed class of such cases, rules of court may provide that any such application as is mentioned in (1) shall be heard and determined by the $\mathrm{HC}$.

(3) Nothing in (1) or (2) shall alter the practice in bankruptcy. ${ }^{218}$

\section{Restrictions on Appeals}

(1) No appeal shall lie to the CA:

(a) except as provided by the Administration of Justice Act 1960, from any judgment of the HC in any criminal cause or matter;

(b) from any order of the $\mathrm{HC}$ or any other court or tribunal allowing an extension of time for appealing from a judgment or order;

(c) from any order, judgment or decision of the $\mathrm{HC}$ or any other court or tribunal which, by virtue of any provision (however expressed) of this or any other Act, is final;

(d) from a decree absolute of divorce or nullity of marriage, by a party who, having had time and opportunity to appeal from the decree nisi on which that decree was founded, has not appealed from the decree nisi;

(e) from a dissolution order, nullity order or presumption of death order under the Civil Partnership Act 2004, Pt 2, ch 2 that has been made final, by a party who, having had time and opportunity to appeal from the conditional order

\footnotetext{
212 This may no longer be necessary if reference to all courts are contained in a Courts Act.

2131981 Act, s 15.

${ }^{214}$ Criminal Appeals Act 1968, ss 2-14, 16-23 \& 28-32.

215 i.e. a leap frogging appeal.

${ }^{216} \mathrm{~S} 56$ (power to prescribe alternative destination for appeals).

${ }^{217} \mathrm{Ibid}, \mathrm{s} 16$. This is re-casting this section. For prize, see n 39.

${ }^{218} 1981$ Act, s 17.
} 
on which that final order was founded, has not appealed from the conditional order;

(f) except as provided by Part I of the Arbitration Act 1996, from any decision of the HC under that Part. ${ }^{219}$

\section{Second Appeals}

(1) Where an appeal is made to the county court, the family court or the HC in relation to any matter, and on hearing the appeal the court makes a decision in relation to that matter, no appeal may be made to the CA from that decision unless the CA considers that:

(a) the appeal would raise an important point of principle or practice, or

(b) there is some other compelling reason for the CA to hear it. ${ }^{220}$

This does not apply in relation to an appeal in a criminal cause or matter.

\section{Assignment of Appeals}

(1) Where in any proceedings in the county court, the family court or the HC a person appeals, or seeks permission to appeal, to a court other than the $\mathrm{CA}$ or the $\mathrm{SC}$ :

(a) the MR, or

(b) the court from which or to which the appeal is made, or from which permission to appeal is sought, or

(c) the President of the Family Division where it is the family court from which or to which the appeal is made, or from which permission to appeal is sought,

may direct that the appeal shall be heard instead by the CA.

(2) The power conferred by (1)(b) shall be subject to rules of court. ${ }^{221}$

\section{8. $\underline{\text { Criminal Appeals }}$}

(1) Subject to (3) a person convicted of an offence on indictment may appeal to the [CA] against his conviction.

(2) An appeal under this section lies only:

(a) with the leave of the CA; or

(b) if, within 28 days from the date of the conviction, the judge of the court of trial grants a certificate that the case is fit for appeal.

(3) Where a person is convicted before the [CC] of a scheduled offence it shall not be open to him to appeal to the [CA] against the conviction on the ground that the decision of the court which sent him to the [CC] for trial as to the value involved was mistaken.

(4) In (3) "scheduled offence" and "the value involved" have the same meanings as they have in the Magistrates' Court, s 22.222

\section{Jurisdiction}

\section{Jurisdiction of the HC}

(1) Subject to the provisions of this Act, there shall be exercisable by the $\mathrm{HC}$ -

(a) all such jurisdiction (whether civil or criminal) as is conferred on it by this or any other Act; and

(b) all such other jurisdiction (whether civil or criminal) as was exercisable by it immediately before the commencement of this Act (including jurisdiction conferred on a judge of the HC by any statutory provision). ${ }^{223}$

(2) Any jurisdiction of the HC shall be exercised only by a single judge of that court, except in so far as it is -

(a) by or by virtue of rules of court or any other statutory provision required to be exercised by a divisional court; or

(b) by rules of court made exercisable by a master, registrar or other officer of the court, or by any other person.

(3) The specific mention elsewhere in this Act of any jurisdiction covered by (1) shall not derogate from the generality of the same. $^{224}$

(4) Sch 10 shall apply to any process relating to an appeal. ${ }^{225}$

\footnotetext{
${ }^{219}$ Ibid, s 18

${ }^{220}$ Access to Justice Act 1999, s 55.

${ }^{221}$ Ibid, s 57.

${ }^{222}$ See Criminal Appeals Act 1968, s 1

${ }^{223}$ See $\mathrm{n} 210$.

${ }^{224} 1981$ Act, s 19.

225 This will set out any administrative provisions in respect of an appeal.
} 


\section{Appeal in Cases of Contempt of Court or Habeas Corpus}

(1) The appeal process in the cases of:

(a) contempt of court; and

(b) habeas corpus

shall be according to Sch $\mathbf{1 1} .{ }^{226}$

\section{Other Courts}

\section{Judicial Committee of the Privy Council ('JCPC')}

(1) The JCPC is abolished and its jurisdiction transferred in accordance with Sch 12.

\section{Court Martial Court of Appeal ('CMCA')}

(1) The CMCA, on a date appointed in an SI, shall become part of the CA and known by the latter title.

\section{3. $\underline{\text { Crown Court ('CC')) }}$}

(1) The CC, on a date appointed in a SI, shall become part of the HC and known by the title, the 'High Court, Criminal Court . 227

(2) The Central Criminal Court ('CCC') shall continue to be known as such. However, none of the mayor, the sheriffs or the aldermen of the City of London shall sit as a judge (or in a judicial seat) in the same. ${ }^{228}$

\section{County and Magistrates 'Courts}

\section{County Court}

(1) The County Court, on a date appointed in a SI, shall:

(a) become part of the HC and known by the latter title; and

(b) a judge of the County Court shall, thereupon, be styled a 'Deputy Justice of the High Court' (or 'Deputy High Court Judge').

(2) A Deputy HC judge shall have the same authority as a HC judge to hear any case before the HC, save where a SI provides otherwise.

\section{Magistrates' Courts}

(1) Any Magistrates' Courts, on a date appointed in a SI, shall:

(a) become part of the $\mathrm{HC}$ and known by the latter title; and

(b) a judge of the Magistrates' Court shall, thereupon, be styled a 'Deputy Justice of the High Court' (or 'Deputy High Court Judge').

(2) A Deputy HC judge shall have the same authority as a HC judge to hear any case before the HC, save where a SI provides otherwise.

\section{$\underline{\text { Obsolete Courts }}$}

\section{Parliament Acting as a Court}

(1) The House of Commons and the House of Lords, whether acting singly or jointly, shall no longer act as a court of law: ${ }^{229}$

(a) without prejudice to the jurisdiction of each house

(b) to punish a breach of privilege by a member of that house.

(2) The following are abolished:

(a) the generic crime of high crimes and misdemeanours;

(b) the criminal process of impeachment;

(c) Acts of Attainder;

\footnotetext{
${ }^{226}$ See AJA 1960, ss 13 (appeal in cases of contempt of court), 14 (procedure on application for habeas corpus), 15 (appeal in habeas corpus proceedings). See also $18(3)$ (NI).

${ }^{227}$ The title 'Criminal Court' fits in with the title 'Central Criminal Court.'

${ }^{228}$ See $\mathrm{n} 83$.

${ }^{229}$ An article on Parliament, n 2, p 103 provides for the HC to try any peerage case and not the HL. Also, pp 101-2, for the (possible) abolition of the HL.
} 
(d) Acts of Pains and Penalties. ${ }^{230}$

(3) Any unrepealed Acts of Attainder and Acts of Pains and Penalties are hereby repealed, as spent.

\section{Other Courts}

(1) The courts in Sch $\mathbf{1 3}$ are abolished, as described.

(2) The criminal jurisdiction of the Verderers Court of the New Forest is transferred to the Magistrates' court:

(a) without prejudice to the Verderer's Court;

(b) dealing with any non-judicial business. ${ }^{231}$

(3) The power of a council of a borough to appoint an honorary recorder under the Courts Act 1971 , s 54 is abolished. ${ }^{232}$

\section{Concurrent Administration of Law and Equity}

(1) Subject to the provisions of this or any other Act, every court exercising jurisdiction in England or Wales in any civil cause or matter shall continue to administer law and equity on the basis that:

(a) wherever there is any conflict or variance

(b) between the rules of equity and the rules of the common law with reference to the same matter,

(c) the rules of equity shall prevail.

(2) Every such court shall give the same effect as hitherto:

(a) to all equitable estates, titles, rights, reliefs, defences and counterclaims, and

(b) to all equitable duties and liabilities; and

(c) subject thereto, to all legal claims and demands and all estates, titles, rights, duties, obligations and liabilities existing by the common law or by any custom or created by any statute, and

(d) subject to the provisions of this or any other Act,

shall so exercise its jurisdiction in every cause or matter before it as to secure that, as far as possible that:

(e) all matters in dispute between the parties are completely and finally determined, and

(f) all multiplicity of legal proceedings with respect to any of those matters is avoided. ${ }^{23}$

(3) Nothing in this Act shall affect the power of the $[\mathrm{SC}],{ }^{234} \mathrm{CA}$ or the $\mathrm{HC}$ to stay any proceedings before it, where it thinks fit to do so:

(a) either of its own motion or on the application of any person,

(b) whether or not a party to the proceedings. ${ }^{235}$

\section{Central Office}

(1) The Central Office of the courts in section 1 [and the CC] shall perform such business as the CJ may, with the concurrence of the LC direct.

[ (2) The CJ may nominate a judicial office holder (as defined in section 109(4) of the Constitutional Reform Act 2005) to exercise his functions under this $[\mathrm{s}].]^{236}$

\section{Accountant General}

(1) There shall continue to be an Accountant General ('A-G') of, and an accounting department for, the CS, CA and HC. ${ }^{237}$

(2) The LC shall appoint such person as he thinks fit to the office of A-G and the person so appointed shall hold and vacate the same in accordance with the terms of his appointment.

\footnotetext{
${ }^{230}$ If the HL is abolished none of (2) is possible anyway.

231 This ancient court has no civil jurisdiction. However, it drafts legislation and deals with administrative matters concerning the New Forest. Such should not be affected.

${ }^{232}$ S 54 (boroughs: honorary offices). '(1) The council of a borough shall have power to appoint a person to be honorary recorder of the borough. (3) A person shall not be qualified to hold office as an honorary recorder of a borough unless he is a Circuit judge or Recorder (that is to say a Recorder appointed under this Act): provided that this [ss] shall not apply to a borough which immediately before the appointed day - (a) had power by charter to appoint a recorder of the borough, and (b) did not have a separate court of quarter sessions.' (obs).

${ }^{233}$ See 1981 Act, s 49. The wording has been further sub-divided, to have make it clearer than presently exists.

234 The 2005 Act fails to apply this section to the SC. However, it should do so.

235 This section replicates the 1981 Act, s 49.

${ }^{236}$ This replicates the 1981 Act, s 96, see 16(a)

${ }^{237}$ If the $\mathrm{CC}$ is not merged, reference to it is also required since it was a senior court.
} 
(3) The A-G shall be paid such salary or fees as the LC determines with the consent of the Treasury.

(4) If one person holds office both as the A-G and as the Public Trustee then, if:

(a) he ceases to be the Public Trustee,

(b) he shall also cease to be the A-G unless the LC otherwise directs.

(5) If a vacancy occurs in the office of A-G or the person appointed to hold the office is for any reason unable to act for any period such person as the LC appoints as deputy in that office shall:

(a) during the vacancy or that period,

(b) perform the functions of that office

(c) and any property vested in the A-G may accordingly be dealt with by the deputy

(d) in all respects as if it was vested in him instead. ${ }^{238}$

\section{Official Solicitor}

(1) There shall continue to be an Official Solicitor ('OS') to the CS, CA and $\mathrm{HC}^{239}$ who shall be appointed by the LC.

(2) There shall be paid to the OS out of money provided by Parliament such salary as the LC may, with the concurrence of the Minister for the Civil Service, determine.

(3) The OS shall have such powers and perform such duties as may for the time being be conferred or imposed on the holder of that office by or:

(a) under this or any other Act; or

(b) in accordance with any direction given (before or after the commencement of this Act) by the LC.

(4) The holder for the time being of the office of OS shall have the right to conduct litigation in relation to any proceedings.

(5) When acting as OS a person who would otherwise have the right to conduct litigation by virtue of the fact that he is a person who, for the purposes of the Legal Services Act 2007, is an authorised person in relation to an activity which constitutes the conduct of litigation (within the meaning of that Act)] shall be treated as having acquired that right solely by virtue of (4)

(6) If a vacancy occurs in the office of A-G or the person appointed to hold the office is for any reason unable to act for any period such person as the LC appoints as deputy in that office shall:

(a) during the vacancy or that period,

(b) perform the functions of that office

(c) and any property vested in the A-G may accordingly be dealt with by the deputy

(d) in all respects as if it was vested in him instead. ${ }^{240}$

\section{Judicial Appointments Commission}

(1) There shall continue to be a Judicial Appointments Commission in accordance with Sch $\mathbf{1 4} .^{241}$

\section{Judicial Appointments and Conduct Ombudsman}

(1) There shall continue to be a Judicial Appointments and Conduct Ombudsman in accordance with Sch $\mathbf{1 5} .^{242}$

\section{Selection of Judges for Election Petitions}

(1) The judges to be placed on the rota for the trial of parliamentary election petitions in England and Wales under the Representation of the People Act 1983, Pt 3 in each year shall be selected:

(a) in such manner as may be provided by rules of court

(b) from the judges of the $[\mathrm{QBD}]^{243}$ of the $\mathrm{HC}$

(c) exclusive of any who are members of the House of Lords.

(2) Notwithstanding the expiry of the year for which a judge has been placed on the rota he may act as if that year had not expired for the purpose of continuing to deal with:

(a) giving judgment in, or

(b) dealing with ancillary matter relating to,

(c) any case with which he may have been concerned during that year.

\footnotetext{
${ }^{238}$ This replicates the SCA 1981, s 97, with minor amendment.

${ }^{239}$ If the $\mathrm{CC}$ is not merged, reference to it is also required since it was a senior court.

${ }^{240}$ This replicates the SCA 1981, s 90 with minor amendment.

${ }^{241} 2005$ Act, s 61.

${ }^{242}$ Ibid, s 62.

${ }^{243}$ If the QBD is abolished this could refer to any HC judge in the civil division.
} 
(3) Any judge placed on the rota shall be eligible to be placed on the rota again in the succeeding or any subsequent year. ${ }^{244}$

\section{5. [District and Probate Registries]}

(1) There shall continue to be:

(a) district registries in accordance with Sch 16; ${ }^{245}$

(b) probate registries in accordance with Sch 17. ${ }^{246}$

\section{Lord Chancellor}

(1) Matters relating to the LC and his office are set out in Sch $18 .{ }^{247}$

(2) When the Great Seal is in commission, the Lords Commissioners shall represent the LC for the purposes of this Act; but the powers vested in him by this Act in relation to -

(a) the appointment of officers, and

(b) any act for which the concurrence or presence of the LC is required by this Act,

may be exercised by the senior Lord Commissioner for the time being. ${ }^{248}$

(3) Any power of the LC in relation to a matter concerning the Church of England (' $\mathbf{C o E}$ '), including:

(a) any power of patronage, or

(b) to act as a visitor

shall be transferred, by a SI, to the Archbishop of Canterbury or to such cleric of the CoE as he may designate. ${ }^{249}$

\section{Chief Justice}

(1) The title of the 'Lord Chief Justice' is now that of 'Chief Justice.'

\section{Other Courts Matters}

\section{Court Buildings}

(1) The High Court and magistrates' courts shall sit in the same building, whenever possible. ${ }^{250}$

\section{Court Websites}

(1) All courts shall host a website which shall set out, in a user-friendly manner:
(a) the physical location of the court;
(b) opening hours;
(c) access issues;
(d) a brief description of the court (including its history);
(e) reference to any general legislation, SI's and rules relating to the court:251
(f) other matters that would be useful to the general public and court users, to know.

\section{Wigs and Robes}

(1) Wigs shall only be worn in the HC, Criminal Court. ${ }^{252}$

(2) A SI shall set out the form of robe to be worn in all courts.

\section{Barrister's Fee}

(1) Any common law restriction on a barrister suing for his fee, is abolished.

\footnotetext{
${ }^{244}$ This replicares SCA 1981, s 142 with minor amendment.

${ }^{245}$ SCA 1981, s 99 (district registries), 100 (district judges), 101 (power of the district registrar to act for another), 102 (deputy district registrars), 103 (assistant district registrars), 104 (district probate registries), 105-28 (probate causes and mattters). This section is only needed if there is no merger of the county and magistrates' courts with the HC.

${ }^{246} \mathrm{Ibid}, \mathrm{s} 104$ (district probate registries), 105-28 (probate causes and matters). This section is only needed if there is no merger of the county and magistrates' courts with the HC.

${ }^{247}$ See 2005 Act, ss 2-18, 19 and sch 7.

${ }^{248}$ See 1981 Act, s 129.

${ }^{249}$ See 16(b).

${ }^{250}$ This assumes that county and magistrates' courts are not merged into the HC. Otherwise, it is unnecessary.

${ }^{251}$ A cross-reference to the government website (legislation.gov.uk) would also be appropriate so that a person can see the actual legislation.

Rules of court should also be put on the government website.

${ }^{252}$ This assumes that the CC is merged into the HC. If not, reference should be made to the CC.
} 


\section{Chief Justice's Report}

(1) After consulting SC, CA and HC judges and the Law Commission, the CJ shall submit an annual report to:

(a) the LC; and to

(b) Parliament (Legal Affairs Committee).

(2) The report shall indicate areas of English law where the CJ believes that:

(a) the court system might be further improved so as to expedite the process of justice;

(b) consolidation of legislation would be useful;

(c) potentially obsolete (or spent) legislation or common law material should be reviewed, for removal;

(d) common law material should be placed in legislation;

(e) reports reviewing areas of English law might, usefully, be issued by the Law Commission;

(f) there are log jams in the court process;

(g) court procedure and rules could be simplified;

(h) there are other concerns of a technical nature.

\section{Law Commission}

(1) The Head of the Law Commission shall submit an annual report to the parties referred to in section 21(1). Such may be combined in the CJ's report.

(2) The report of the Head of the Law Commission, in his report, shall, in particular,

(a) indicate the matters referred to in section 21(2)b)-(e);

(b) provide a table of general legislation enacted prior to 1925 which still exists and the extent to which it may be repealed or consolidated as expeditiously as possible;

(c) indicate the progress in consolidating legislation, in particular, in the following areas of law: (i) criminal law; (ii) constitutional law; (iii) commercial law; (iv) land law. ${ }^{253}$

(3) Every 5 years the Law Commission shall place on its website (and publish in hardcopy) a list of local and private legislation which have not yet been repealed as well as its rate of progress in so doing.

\section{Publication of Information relating to Private Proceedings}

(1) The publication of information relating to proceedings before any court sitting in private shall not, of itself, be contempt of court except in the following cases, that is to say where the:

(a) proceedings:

(i) relate to the exercise of the inherent jurisdiction of the $\mathrm{HC}$ with respect to minors; or

(ii) are brought under the Children Act 1989 or the Adoption and Children Act 2002; or

(iii) otherwise relate wholly or mainly to the maintenance, or upbringing, of a minor.

(b) proceedings are brought under the Mental Capacity Act 2005 or under any provision of the Mental Health Act 1983] authorising:

(i) an application or reference to be made to the First-tier Tribunal, or

(ii) the Mental Health, or

(iii) a Review Tribunal for Wales, or

(iv) the county court;

(c) court sits in private for reasons of national security during that part of the proceedings about which the information in question is published;

(d) information relates to a secret process, discovery or invention which is in issue in the proceedings;

(e) the court (having power to do so) expressly prohibits the publication of all information relating to the proceedings or of information of the description which is published.

(2) Without prejudice to (1), the publication of the text or a summary of the whole (or part) of an order made by a court sitting in private shall not:

(a) of itself

(b) be contempt of court

(c) except where the court (having power to do so) expressly prohibits the publication.

(3) In this section references to a court include references to a judge and to a tribunal and to any person exercising the functions of a court, a judge or a tribunal; and references to a court sitting in private include references to a court sitting in camera or in chambers.

${ }^{253}$ These tend to be the only areas the Law Commission now deals with. 
(4) Nothing in this section shall be construed as implying that any publication is punishable as contempt of court which would not be so punishable apart from this section (and in particular where the publication is not so punishable by reason of being authorised by rules of court). ${ }^{254}$

\section{$\underline{\text { Legislation }}$}

\section{5. $\underline{\text { Responsibility }}$}

(1) All Government ministries shall:

(a) on their websites:

(i) list all general legislation and SI's for which they are responsible

(ii) list all agencies, other public bodies and high profile groups, which they fund or for which they are responsible;

(iii) provide other useful data so as to enable a reader to obtain a comprehensive overview of the ministry, how it is structured and how it operates.

(b) publish, in an annual Ministerial Handbook:

(i) the text of all general legislation and SI's for which they are responsible (excluding repealed matter);

(ii) the data in (1)(a)(ii) and (iii).

\section{Consolidation}

(1) All ministries must consolidate all general legislation for which they are responsible into one (or more) consolidation Acts.

(2) Subsequent to (1), further review and consolidation must be undertaken every 5 years.

(3) All ministries must consolidate all SI's for which they are responsible:

(a) into one (or more) SI's (of, up to, 600 articles),

(b) commencing with the earliest.

(4) Subsequent to (3), further review and consolidation must be undertaken every 3 years.

\section{Form}

(1) Legislation shall bear simple titles, so that their purport may be readily understood.

(2) All:

(a) criminal legislation shall be consolidated into one, or more, Crime Acts;

(b) land legislation shall be consolidated into one, or more, Land or Landlord and Tenant Acts;

(c) commercial legislation shall be consolidated into one, or more, Commerce Acts;

(d) constitutional legislation shall be consolidated into one, or more, Acts;

(e) military (armed forces) legislation shall be consolidated into one, or more, Armed Forces Acts;

(f) companies legislation shall be consolidated into one, or more, Companies Acts;

(g) shipping legislation shall be consolidated into one, or more, Shipping Acts;

(h) aviation legislation shall be consolidated into one, or more, Aviation Acts;

(i) railway legislation shall be consolidated into one, or more, Railway Acts;

(j) highway legislation shall be consolidated into one, or more, Road Acts;

(k) road transport legislation shall be consolidated into one, or more, Road Transport Acts;

(1) environmental legislation shall be consolidated into one, or more, Environment Acts;

(m) legislation relation to London shall be consolidated into one, or more, London Acts.

(3) Preambles in legislation shall kept brief, where possible.

(4) In the case of criminal legislation, the standard wording for any indictment, and the punishment for the crime:

(a) shall be set out in a Schedule to the relevant Act,

(b) to permit easier amendment.

\section{Local and Private}

(1) Any local, or private, legislation may be repealed by means of an SI, subsequent to a report issued by the Law Commission that the same is obsolete or spent.

\footnotetext{
${ }^{254}$ See AJA 1960, s 12.
} 


\title{
$\underline{\text { General }}$
}

59. $\underline{\text { Repeals }}$

(1) The legislation Sch 19 is repealed.

\section{Supplementary}

(1) Any legislation or common law matter attendant on, or consequential to, sections $31-37$ may be:
(a) repealed;
(b) abolished; or
(c) amended,

by a SI.

\section{Interpretation and Application}

(1) In this Act:
(a) ' $B O T$ ' refers to a British Overseas Territory;
(b) ' $C J$ ' means the Lord Chief Justice;
(c) "devolution matter" means:

(i) a question referred to the SC under sections 99 or 112 of the Government of Wales Act 2006 or section 33 of the Scotland Act 1998 or section 11 of the Northern Ireland Act 1998;

(ii) a devolution issue as defined in Sch 9 to the Government of Wales Act 2006 or Sch 6 to the Scotland Act 1998 or Sch 10 to the Northern Ireland Act 1998.

(d) 'Foreign Country' for the purposes of this Act refers to a country not the UK or a BOT;

(e) 'judicial office holder' means as defined in s 109(4) of the Constitutional Reform Act 2005);

(f) ' $L C$ ' means the Lord Chancellor;

(g) ' $M R$ ' means the Master of the Rolls;

(h) 'Sch' means schedule;

(i) ' $\mathrm{SI}$ ' refers to a statutory instrument;

(j) ' $U K$ ' refers to the United Kingdom.

(2) This Act applies to Scotland and Northern Ireland.

Schedule 1 (Divisions of the CA)

Schedule 2 (Divisions and Courts of the HC)

Criminal Court

Family Court

Admiralty Court ${ }^{255}$

Commercial Court

Administrative Court

Technology and Construction Court

Bankruptcy Court

Companies Court

Patents Court

\author{
Schedule 3 (Powers of the HC) \\ $\underline{\text { Schedule } 4 \text { (Due Constitution) }}$ \\ Schedule 5 (Rules of Court) \\ $\underline{\text { Schedule } 6 \text { (Judicial Assistance) }}$ \\ Schedule 7 (Process for Criminal Appeals from the CA to the CS) \\ Schedule 8 (Process for Criminal Appeals from the HC to the CS) \\ Schedule 9 (Proces for Appeals to the CA) \\ $\underline{\text { Schedule } 10 \text { (Jurisdiction of the HC) }}$ \\ Schedule 11 (Appeals re Contempt of Court or Habeas Corpus)
}

${ }^{255}$ Consideration should be given to expanding this to become a Transport Court. 


\section{$\underline{\text { Schedule } 12 \text { (Transfer of Jurisdiction of the JCPC) }}$}

(1) The jurisdiction of the JCPC to hear an appeal:

(a) from the disciplinary committee of the Royal College of Vets, shall pass to the HC;

(b) against a scheme of the church commissioners under the Mission and Pastoral Measure 2011, shall pass to the HC;

(c) from an admiralty court in a BOT in respect of prize, shall pass to the HC;

(d) from the Arches Court of Chancery (or Chancery Court of York), shall pass to the CA;

(e) from a court of a BOT, or from any other foreign country, shall pass to the SC;

(f) in respect of any other matter, shall pass to the SC or as transferred by an SI. ${ }^{256}$

(2) The

(a) House of Commons Disqualification Act 1975, section 7; and the

(b) Veterinary Surgeons Act 1966, section 17

shall be amended to refer to the High Court instead of the JCPC.

Schedule 13 (Obsolete Courts)

1. The following are abolished, as described, the:

(a) courts referred to in the Administration of Justice Act 1977, sch 4, parts 1, 2 and 3;

(b) Court of the Chamberlain of the City of London;

(c) Court of the Duchy Chamber of Lancaster;

(d) High Court of Chivalry;

(e) Cinque Ports Court of Admiralty;

(f) Courts of the Vice-Admirals of the Coast;

(g) Court of the Lord High Steward;

(h) Court of Claims;

(i) Court of Attachment (40 Days Court) of the New Forest;

(j) Court of Attachment (40 Days Court) of the Forest of Dean;

(k) Court of the Verderers of the Forest of Dean (also, called the Court of Swainmote or Swanimote of the Forest of Dean);

(1) Barmote courts of the High Peak and Wirksworth;

(m) judicial jurisdiction of the:

(i) Royal Court of Shepway; and

(ii) the Court of Brotherhood and Guestling,

without prejudice to the right of the same to ceremonially assemble in order to elect a Lord Warden of the Cinque Ports.

2. In the case of the court:

(a) in 1(a), any jurisdiction of any court referred to in parts 1-3 shall pass to the:

(i) county court in the case of civil jurisdiction;

(ii) magistrates' court in the case of criminal jurisdiction. ${ }^{257}$

Further, the abolition of any manorial court shall not affect any manor being held, legally, to be such;

(b) in 1(d), any armorial jurisdiction it has shall transfer to the High Court;

(c) in 1(e), any admiralty jurisdiction it has shall transfer to the High Court, Admiralty Division;

(d) in 1(h), the persons who shall have the right to personally attend the sovereign at his (her) coronation, shall be set out in a SI.

Schedule 14 (Judicial Appointments Commission)

Schedule 15 (Judicial Appointments and Conduct Ombudsman)

Schedule 16 (District Registrv)

Schedule 17 (Probate Registry)

\section{Schedule 18 (Lord Chancellor)}

\section{$\underline{\text { Schedule } 19 \text { (Repeals) }}$}

[All the legialation referred to in Appendix $A$ shall be repealed, save where the same is placed in any Justice Act].

\footnotetext{
${ }^{256}$ It may be noted that HM may refer any legal matter to the JCPC for consideration and report. If still required, this function should be transferred to the SC.

${ }^{257}$ Reference should be made to the HC, if the county and magistrates' courts are merged with the same.
} 


\section{Copyright}

Copyright for this article is retained by the author(s), with first publication rights granted to the journal.

This is an open-access article distributed under the terms and conditions of the Creative Commons Attribution license (http://creativecommons.org/licenses/by/4.0/). 